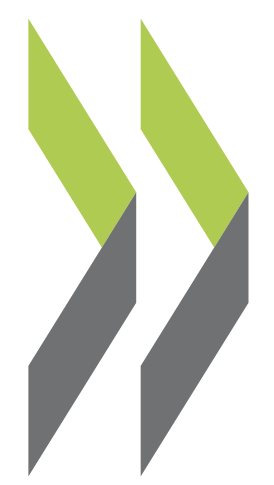

OECD Social, Employment and Migration Working Papers No. 131

\title{
Eligibility Criteria
} for Unemployment Benefits: Quantitative Indicators for OECD and EU Countries

\section{Danielle Venn}

https://dx.doi.org/10.1787/5k9h43kgkvr4-en 
Organisation de Coopération et de Développement Économiques

Organisation for Economic Co-operation and Development

09-Jan-2012

DIRECTORATE FOR EMPLOYMENT, LABOUR AND SOCIAL AFFAIRS

English - Or. English

EMPLOYMENT, LABOUR AND SOCIAL AFFAIRS COMMITTEE

OECD SOCIAL, EMPLOYMENT AND MIGRATION WORKING PAPERS No. 131

ELIGIBILITY CRITERIA FOR UNEMPLOYMENT BENEFITS: QUANTITATIVE INDICATORS FOR OECD AND EU COUNTRIES

Danielle Venn

Please contact Danielle Venn (danielle.venn@oecd.org, +33 1452475 01). All Social, Employment and Migration Working Papers are available on www.oecd.org/els/workingpapers.

JT03314064

Document complet disponible sur OLIS dans son format d'origine

Complete document available on OLIS in its original format 


\title{
DIRECTORATE FOR EMPLOYMENT, LABOUR AND SOCIAL AFFAIRS
}

www.oecd.org/els

\section{OECD SOCIAL, EMPLOYMENT AND MIGRATION WORKING PAPERS}

\author{
www.oecd.org/els/workingpapers
}

This series is designed to make available to a wider readership selected labour market, social policy and migration studies prepared for use within the OECD. Authorship is usually collective, but principal writers are named. The papers are generally available only in their original language - English or French - with a summary in the other.

Comment on the series is welcome, and should be sent to the Directorate for Employment, Labour and Social Affairs, 2, rue André-Pascal, 75775 PARIS CEDEX 16, France.

The opinions expressed and arguments employed here are the responsibility of the author(s) and do not necessarily reflect those of the OECD.

Applications for permission to reproduce or translate all or part of this material should be made to:

\author{
Head of Publications Service \\ OECD \\ 2, rue André-Pascal \\ 75775 Paris, CEDEX 16 \\ France
}

Copyright OECD 2011 
DELSA/ELSA/WD/SEM(2012)1

\section{ACKNOWLEDGEMENTS}

Danielle Venn is an Economist in the Employment Analysis and Policy Division of the Directorate for Employment, Labour and Social Affairs of the OECD. This paper would not have been possible without the cooperation of delegates to the OECD Employment, Labour and Social Affairs Committee and the Indicator Sub-Group of the European Commission's Social Protection Committee. Many thanks to David Grubb for preparing the questionnaire from which data for this paper were drawn and for his advice during the completion of the paper. Thanks also to Kornelia Kosovska and Isabel Maquet from the European Commission for their help in obtaining questionnaire responses from non-OECD member countries and to Mark Keese and Linda Richardson for helpful comments. This project was funded by the European Union. 


\section{SUMMARY}

Eligibility criteria for unemployment benefits, which require recipients to actively look for work, take up suitable job offers or take part in active labour market programmes (ALMPs), or risk benefit sanctions, can play an important role in offsetting the negative impact of generous unemployment benefits on employment incentives. This paper presents information on the strictness of eligibility criteria for unemployment benefits for $36 \mathrm{OECD}$ and/or EU member countries. It covers entitlement conditions (employment and/or contribution requirements to gain access to benefits and sanctions for voluntary unemployment), job-search requirements (availability requirements during ALMPs and suitable work criteria), monitoring of job-search effort and sanctions for refusing a job offer or ALMP placement. These qualitative data are then used to compile a composite indicator of the strictness of eligibility criteria and some comparisons are made with the results of a similar exercise for earlier periods. This indicator complements existing cross-country indicators relating to unemployment benefits, such as net replacement rate data from the OECD Tax and Benefits database and data on ALMP expenditure compiled annually by Eurostat and the OECD.

\section{RÉSUMÉ}

Les critères d'éligibilité aux allocations de chômage, comme l'obligation de chercher activement un emploi, d'accepter les offres d'emploi convenables ou de participer à des programmes actifs du marché du travail (PAMT), ou bien le risque de sanction par rapport aux prestations, peuvent jouer un rôle important pour compenser l'effet négatif des allocations de chômage généreuses sur les incitations à l'emploi. Ce document présente des informations sur la rigueur des conditions d'éligibilité pour les allocations de chômage dans 36 pays de l'OCDE et/ou membres de l'UE. Il décrit les conditions d'accès aux prestations (période d'emploi et/ou de contribution requise et sanctions en cas de chômage volontaire), les obligations de recherche d'emploi (disponibilité pour les participants aux PAMT et critère d'emploi convenable), le contrôle des efforts de recherche d'emploi et les sanctions en cas de refus d'une offre d'emploi ou d'une proposition de participation à une mesure active du marché du travail. Ces données qualitatives sont ensuite utilisées pour construire un indicateur composite de la rigueur des critères d'éligibilité et effectuer des comparaisons avec des résultats d'exercices similaires pour des périodes antérieures. Cet indicateur complète les autres indicateurs disponibles relatifs aux prestations de chômage, tel les taux de remplacement issus de la base de données de l'OCDE prestations et salaires et les données sur les dépenses publiques des PAMT compilées annuellement par Eurostat et l'OCDE. 


\section{TABLE OF CONTENTS}

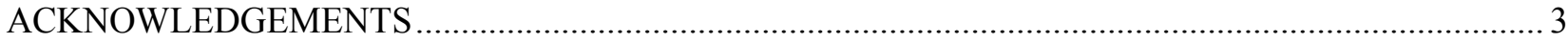

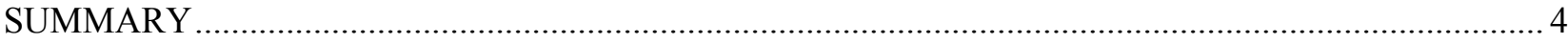

RÉSUMÉ

ELIGIBILITY CRITERIA FOR UNEMPLOYMENT BENEFITS: QUANTITATIVE INDICATORS FOR

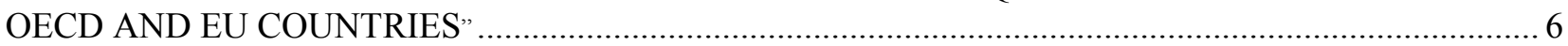

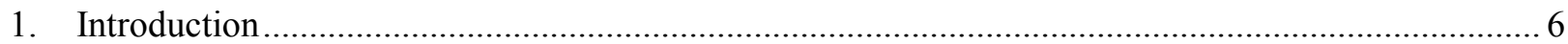

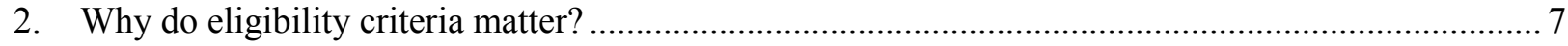

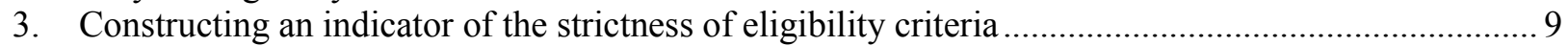

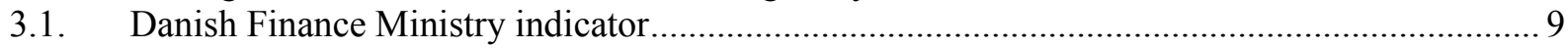

3.2. A revised indicator of the strictness of eligibility criteria ..................................................... 10

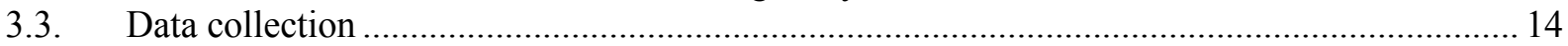

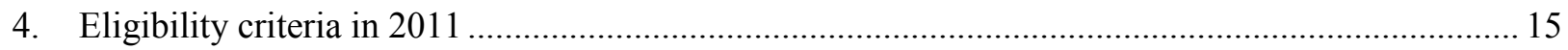

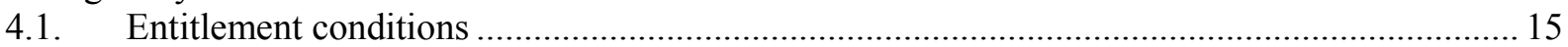

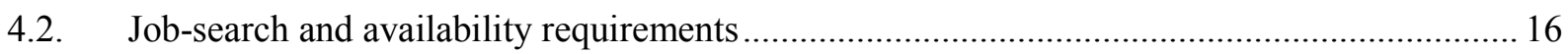

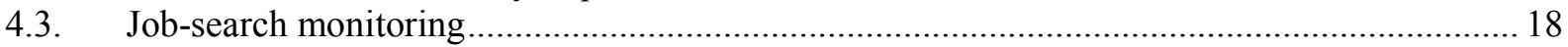

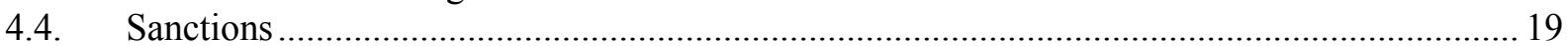

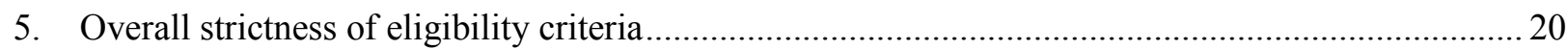

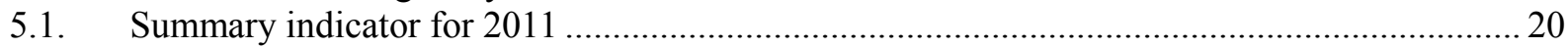

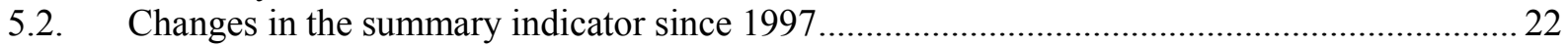

5.3. Eligibility criteria, benefit generosity and ALMP expenditure ............................................. 24

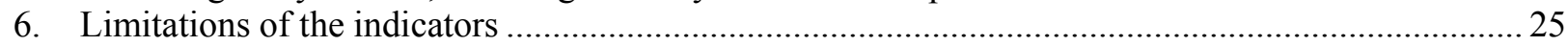

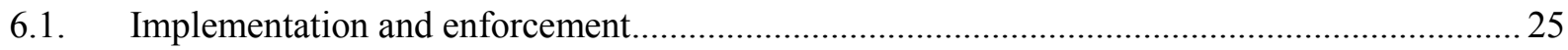

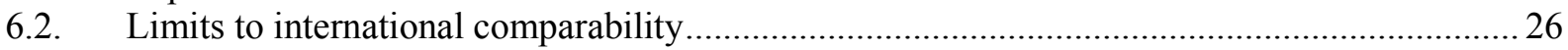

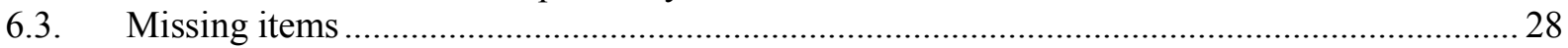

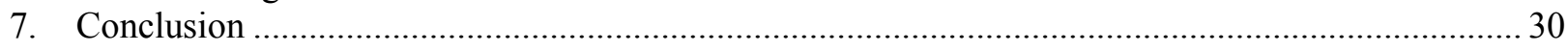

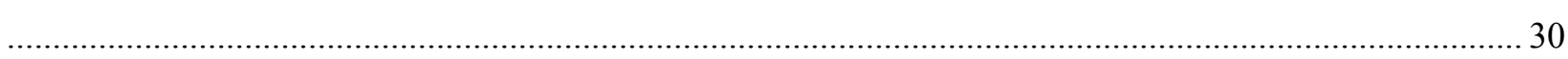

ANNEX A: COMPARISON WITH DANISH FINANCE MINISTRY INDICATOR …........................... 31

ANNEX B: DETAILED DESCRIPTION OF ELIBILITY CRITERIA AND SANCTIONS .................... 34

ANNEX C: ADDITIONAL ITEMS ON MONITORING FOR SELECTED COUNTRIES .....................57

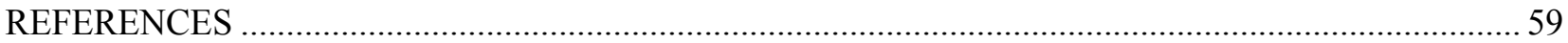

\section{Boxes}

Box 1. How much difference do the weights make?

Box 2. Expanding the indicator: an example for monitoring ..............................................................29 


\section{ELIGIBILITY CRITERIA FOR UNEMPLOYMENT BENEFITS: QUANTITATIVE INDICATORS FOR OECD AND EU COUNTRIES ${ }^{1,2,3}$}

\section{Introduction}

1. Unemployment benefits help households to smooth consumption when faced with job loss, give the unemployed time to find a new, well-matched job and operate as an automatic stabiliser over the business cycle. Nevertheless, there is a widespread consensus that a more generous level and duration of unemployment benefits is associated with longer unemployment duration and higher aggregate unemployment, other things being equal. However, other features of unemployment benefit systems notably requirements that benefit recipients actively look for work, take up suitable job offers or take part in active labour market programmes (ALMPs), or risk benefit sanctions - can play an important role in offsetting the negative impact of generous benefits. Coverage may also be important; if few workers are entitled to claim unemployment benefits after job loss, benefits may have little impact on aggregate labour market outcomes, no matter how generous they are.

2. This paper presents information on the strictness of eligibility criteria for unemployment benefits for $36 \mathrm{OECD}$ and/or EU member countries. It covers entitlement conditions (employment and/or contribution requirements to gain access to benefits and sanctions for voluntary unemployment), job-search requirements (availability requirements during ALMPs and suitable work criteria), monitoring of jobsearch effort and sanctions for refusing a job offer or ALMP placement. These qualitative data are then used to compile a composite indicator of the strictness of eligibility criteria. This indicator complements existing cross-country indicators relating to unemployment benefits, such as net replacement rate data from the OECD Tax and Benefits database and data on ALMP expenditure compiled annually by Eurostat and the OECD.

3. The paper is organised as follows. Section 2 discusses the existing theoretical and empirical literature in order to provide a framework for thinking about why eligibility criteria may affect labour market outcomes. Section 3 outlines the methodology used to calculate the indicators presented in the paper, comparing the indicators with an earlier indicator compiled by the Danish Finance Ministry. Section 4 summarises eligibility criteria strictness in place in OECD and EU member countries in 2011 and presents four sub-indicators of the strictness of eligibility criteria. Section 5 discusses the overall strictness of eligibility criteria, as measured by the indicators, and changes over time. Section 6 highlights some limitations of the indicator and presents some ideas for future research. A short conclusion follows in Section 7.

1. Data for Israel are supplied by and under the responsibility of the relevant Israeli authorities. The use of such data by the OECD is without prejudice to the status of the Golan Heights, East Jerusalem and Israeli settlements in the West Bank under the terms of international law.

2. Footnote by Turkey: The information in this document with reference to "Cyprus" relates to the southern part of the Island. There is no single authority representing both Turkish and Greek Cypriot people on the Island. Turkey recognizes the Turkish Republic of Northern Cyprus (TRNC). Until a lasting and equitable solution is found within the context of United Nations, Turkey shall preserve its position concerning the "Cyprus issue".

3. Footnote by all the European Union Member States of the OECD and the European Commission: The Republic of Cyprus is recognized by all members of the United Nations with the exception of Turkey. The information in this document relates to the area under the effective control of the Government of the Republic of Cyprus. 
DELSA/ELSA/WD/SEM(2012)1

\section{Why do eligibility criteria matter?}

4. Many theoretical models of the labour market have been developed to examine the likely impact of unemployment benefit system parameters, such as unemployment level and duration, on labour market outcomes, and to consider the optimal design of unemployment benefit systems (see Fredriksson and Holmlund, 2006, for a survey). Basic search models typically assume that utility increases with consumption (and thus income from work and/or benefits) and decreases with the effort put into job search (because time spent on job search reduces leisure time). Unemployed people can influence the rate at which they move from unemployment into work by increasing their job-search effort and/or reducing their reservation wage (i.e. the wage at which they will accept a job, rather than remain unemployed), although labour market conditions also play a role. Such models predict that more generous unemployment benefits (both in terms of replacement rate and duration) reduce the likelihood of unemployment benefit recipients finding work, increasing the length of unemployment spells. When replacement rates are higher, the cost of unemployment (the gap between the wage and the unemployment benefit) is smaller, reducing incentives to look for or take up work. Search effort will increase when the unemployed person reaches the end of their benefit period because income (and consumption) will fall once benefits end. ${ }^{4}$ However, more generous benefits may also increase job-search effort by unemployed persons who are not receiving benefits, because the benefit of having a job (and thus future entitlement to unemployment benefits) increases. There is considerable empirical evidence that more generous benefits are associated with longer unemployment duration and higher aggregate levels of unemployment (see OECD, 2006, for a survey).

5. Basic search models typically assume that all unemployed people are entitled to a given level and duration of unemployment benefits, and many empirical studies use level and duration as a proxy for the generosity of benefits. In reality, access to benefits is generally denied to those who have not made a minimum contribution to unemployment insurance schemes and/or who do not have a minimum prior employment record. Benefits may be delayed or withdrawn altogether if the unemployed person contributed to their own unemployment by resigning or being dismissed for cause from their previous job. Even if an unemployed person is eligible for benefits after becoming unemployed, on-going eligibility may depend on compliance with job-search-related requirements, such as looking for jobs, attending interviews and accepting suitable job offers. Job-search and other administrative requirements typically are backed up by sanctions, such as reduction or suspension of benefits, for non-compliance.

6. From a theoretical perspective, job-search requirements can influence unemployment outcomes by affecting the reservation wage and/or job-search intensity of unemployment benefit recipients (Fredriksson and Holmlund, 2006). Most theoretical models that examine the impact of job-search requirements introduce job-search monitoring and sanctions into the basic search model (Boone and van Ours, 2007; Abbring et al., 2005; Fredriksson and Holmlund, 2001; Boone et al., 2006). Unemployment benefit recipients receive a sanction if they do not comply with job-search requirements. Utilitymaximising unemployment benefit recipients will increase their search effort, either ex post (i.e. when their income drops after receiving a sanction) or ex ante (i.e. to reduce the risk of receiving a sanction in the future). Greater search effort increases the likelihood of finding work, reducing unemployment duration. Duration may also fall if sanctions (or the threat of sanctions) encourage jobseekers to take up job offers that they might otherwise reject. Suitable work criteria, which outline the types of job offers that benefit recipients must accept, directly affect reservation wages (Ljungqvist and Sargent, 1995). ${ }^{5}$ Strict suitable

4. This effect holds even if the unemployed are entitled to social assistance when their period of unemployment benefit entitlements ends, as long as social assistance is less generous than unemployment benefits.

5. However, by compelling benefit recipients to take up lower paid or poorer quality jobs or jobs that do not suit their personal circumstances, strict suitable work criteria could also increase the likelihood of future unemployment. 
work criteria could also reduce workers' incentives to quit their jobs and rely on benefits because of the increased risk that they will have to take up a job that is inferior to their previous job. This would tend to reduce inflows to unemployment.

7. A number of empirical studies confirm theoretical expectations about the ex post effect of sanctions. Receiving a sanction has been found to increase the number of months in employment in the following 12 months by $0.6-0.8$ months in Germany and increase the exit rate from welfare to work in the Netherlands by up to 100\% (Hofmann, 2008; van den Berg et al., 2004; Abbring, et al., 2005). In Switzerland, jobseekers are issued with a warning prior to receiving a sanction (only around one-third of those issued with a warning actually receive a sanction). Lalive et al. (2005) find that receiving a warning increases the exit rate from unemployment by $25 \%$ and the sanction itself increases the exit rate by $20 \%$.

8. In most countries, very few unemployment benefit recipients actually receive a sanction for breaching eligibility rules. In the mid- to late-1990s, sanction rates for labour-market behaviour (not including sanctions for administrative infractions) while receiving benefits (as opposed to those before benefit receipt commences) were typically less than $10 \%$ in the countries for which data were available, the exceptions being Switzerland (38\%) and the United States (35\%) (Gray, 2003). ${ }^{6}$ Thus for most unemployment benefit recipients, the threat of sanctions is the main way in which sanctions can plausibly affect job-search behaviour. Because of the difficulty in identifying ex ante effects, few studies have empirically estimated their importance. An exception is Lalive et al. (2005), who use regional variation in the imposition of sanction warnings in Switzerland to proxy differences in monitoring intensity. They find that increasing the warning rate by $64 \%$ reduces average unemployment duration by seven days. An experimental, laboratory-based study by Boone et al. (2009) also found significant ex ante effects of sanctions, which in many circumstances are larger than the ex post effects.

9. In addition to empirical studies of the impact of sanctions, several studies have examined the effects of specific job-search requirements on the likelihood of exiting unemployment benefits. Johnson and Klepinger (1994) find that unemployment benefit recipients subject to job-search reporting requirements have shorter unemployment durations than those without reporting requirements, which they attribute to greater job-search effort rather than a reduction in reservation wages. Olsson (2009) introduces geographical mobility requirements into a matching model of the Swedish labour market. He finds that requirements to search for jobs more widely are effective in increasing the probability of finding a job, but only when the number of vacancies is similar to the number of jobseekers. In the case of Sweden where there are only 0.06 vacancies advertised with the PES for each unemployed person, mobility requirements have very little impact on the probability of finding a job.

10. In summary, many recent studies point to factors other than the level or duration of unemployment benefits as plausible explanations for the duration of unemployment and/or benefit dependency. A number of studies have sought to compile (mainly) qualitative information for OECD and EU countries on various eligibility criteria. The OECD Benefits and Wages website (www.oecd.org/els/workincentives) provides information on employment and contribution requirements for entitlement to unemployment benefits. Council of Europe (2009) examines suitable work criteria for EU member countries. A number of OECD studies have examined eligibility criteria and interventions in the unemployment spell across OECD countries (Grubb, 2001; OECD, 2000; OECD, 2007). These studies provide useful information on a range of eligibility criteria for a number of OECD countries, but limited information on changes through time.

11. Despite these studies, most cross-country empirical studies of unemployment benefit systems and their impact on labour market outcomes continue to focus on replacement rates (often adjusted for

6. Sanction rates are defined as total annual sanctions divided by the average stock of benefit recipients. 
maximum benefit duration), as a proxy for unemployment benefit generosity, and expenditure on, or participation in, ALMPs, as a proxy for the strictness of activation requirements. This suggests that researchers do not have access to reliable cross-country quantitative data on eligibility criteria to use in these types of analyses.

12. Two studies by the Danish Foreign Ministry (Ministry of Finance, 1998; Hasselpflug, 2005) are notable exceptions. These studies presented an indicator of the strictness of eligibility criteria for a large sample of countries for two points in time. For whatever reason, this indicator, hereafter referred to as the DFM indicator, has not attracted much attention from researchers. The DFM indicator in its present form has some weaknesses, which are discussed in more detail in the next section. However, it provides a good basis for constructing an indicator of the strictness of eligibility criteria, which may be useful in further explaining how unemployment benefits affect unemployment outcomes.

\section{Constructing an indicator of the strictness of eligibility criteria}

\subsection{Danish Finance Ministry indicator}

13. The DFM indicator incorporates information on eight aspects of eligibility and sanctions: (i) proof of job-search activity; (ii) requirements to be available for work during participation in ALMPs; (iii) demands on occupational mobility; (iv) demands on geographical mobility; (v) other valid reasons for refusing job offers; (vi) sanctions in case of resignation from previous job; (vii) sanctions for refusing a job offer or refusing to participate in an ALMP; and (viii) sanctions for repeated refusal of job offers or ALMP participation. Each component is given a score of between 1 (least strict) and 5 (most strict) and the overall indicator is the weighted average of the individual components. The weight assigned to each component ranges from 0.25 to 1 , with the size of each weight reflecting the strength of the component in influencing job availability and, to some extent, judgements about the reliability of data collected for each item (Ministry of Finance, 1998).

14. The DFM indicator has a number of strengths. First, it covers many of the characteristics of eligibility criteria that theoretical and empirical studies outlined in the previous section suggest could be important in influencing unemployment outcomes. Second, the burden on respondents of providing information on the eight items used to compile the indicator is relatively light because it focuses on aspects of eligibility criteria that are relatively easy to codify. Third, data are already available for two earlier data points (1997 and 2003/04), so that it should be possible in principle to create a time-series to track changes over time.

15. However, a review of the coding of information by Ministry of Finance (1998) and Hasselpflug (2005) showed some inconsistencies in the application of the coding framework between the two points in time. For example, for France, the description "The unemployed must provide evidence of job search when contacted by the authorities" is given a score of 3 in 1997 and "The unemployed are examined every four months" is given a score of 1 in 2003/04, despite the latter arguably demonstrating a more regular or systematic job-search requirement than the former. The interpretation of the coding framework for several items was also ambiguous. For example, under the item concerning valid reasons for refusing job offers, countries were grouped by whether they had a "relatively large amount", "average amount" or "relatively 
few" valid reasons, with little guidance as to how these distinctions were made. ${ }^{7}$ Likewise, under the item concerning geographical mobility, there was some overlap in the categories for required travel time. ${ }^{8}$

16. In addition, the coding framework for the item concerning sanctions for repeated refusal of job offers or ALMP participation was structured in such a way that the resulting country rankings did not reflect the relative strength of sanctions. For example, under the existing categories, Malta would receive a score of 1 ("no further sanction in case of repeated refusal") and the Netherlands a score of 3 ("sanctions are more rigorous after the second rejection") even though the sanction for repeatedly refusing a job offer in the Netherlands is a $50 \%$ reduction in benefits for four months while in Malta the sanction is a complete suspension of benefits for six months for each refusal.

17. Finally, the indicator does not include information on the employment or contribution conditions that unemployed people must meet in order to be entitled to unemployment benefits. While these do not affect on-going eligibility for benefits, they are important in determining initial coverage of benefits and would complement information in the DFM indicator on sanctions for voluntary unemployment.

18. In light of these problems with the DFM indicator, this paper presents a revised indicator for the strictness of eligibility criteria. However, by maintaining as far as possible the items from the DFM indicator, it is possible to recalculate the previous data points (1997 and 2003/04) using the descriptive information provided in Ministry of Finance (1998) and Hasselpflug (2005), as well as data from the OECD Benefits and Wages database, allowing comparison of eligibility criteria over a relatively long time period. Revising the coding methodology also provides the opportunity to refine some of the categories to provide more differentiation between countries, add a new category on employment and contribution conditions for entitlement to benefits, as well as to revisit the weights used to aggregate the individual categories into sub-indicators and into an overall summary indicator. The revised methodology is outlined in Section 3.2.

\subsection{A revised indicator of the strictness of eligibility criteria}

19. Figure 1 shows the coding framework used to compile the eligibility criteria indicator. The revised indicator comprises nine items describing various aspects of eligibility criteria and sanctions. It covers the items from the DFM indicator plus an additional item relating to employment and/or contribution requirements to be eligible to receive unemployment benefit. A comparison of each item with those in the DFM indicator is at Annex A. The items were chosen to take advantage of data collected for the DFM indicator and the OECD Benefits and Wages database in order to create a time series of observations for as many countries as possible. However, there are arguably some areas that may be important in influencing unemployment outcomes but are not included in the indicator. These omissions and issues of implementation and enforcement of eligibility criteria will be discussed in Section 6 .

\footnotetext{
7. Hasselpflug (2005), recognizing that "the answers to the questionnaire might not give an extensive list of the valid reasons", attributed a low weight ( 0.25 from a total of 6.25) to the score on this item.

8. The categories include that the unemployed must accept daily transportation time of " $1-2$ ", "2-3" and "3-4" hours per day.
} 
Figure 1. Coding framework

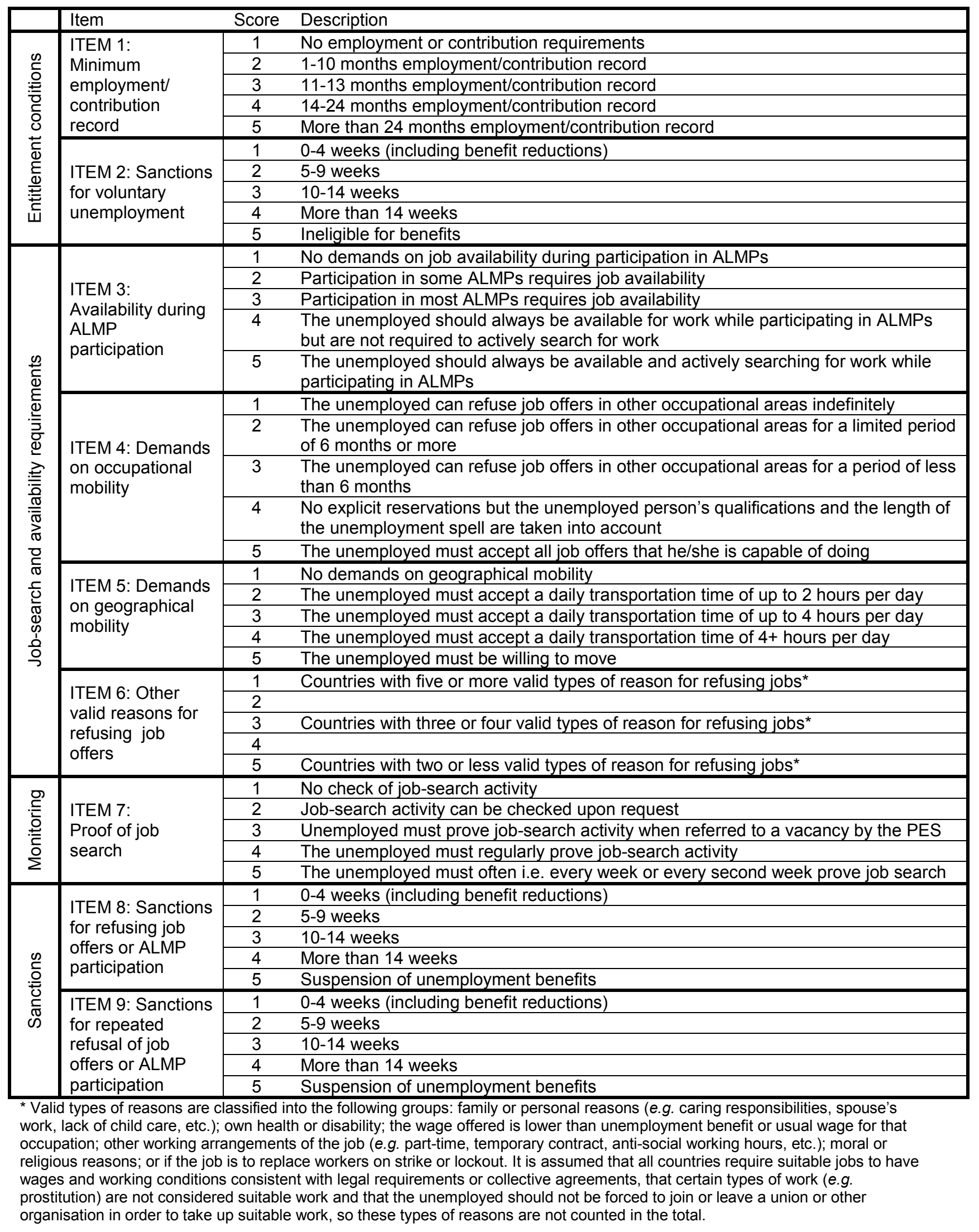


20. Countries are allocated a score for each item from one (least strict) to five (most strict) on each of the nine items. The first two items describe the conditions that determine initial entitlement to benefits. Item 1 describes the employment and contribution conditions necessary to be eligible for unemployment benefits. Where employment and contribution conditions differ, the score was derived based on the minimum amount of time a full-time worker would need to be employed and contributing before becoming eligible for benefits. ${ }^{9}$ Item 2 describes the sanctions that apply if a person becomes unemployed through their own fault. This could include voluntarily quits or dismissals for cause. ${ }^{10}$ In most countries, sanctions take the form of a suspension of benefits for a certain number of weeks or non-eligibility for benefits to begin with, although in a small number of cases, benefits are paid at a reduced replacement rate. ${ }^{11}$

21. Items 3 to 6 relate to availability for work while participating in ALMPs and the type of job offers that benefit recipients are obliged to take up, referred to in this paper as job-search and availability requirements. Item 3 describes whether a benefit recipient must be available and actively searching for work while participating in ALMPs such as training programmes or work experience placements. General availability and job-search criteria that apply to ordinary unemployment benefit recipients may be suspended if participation in the ALMP results in a movement to a different income support payment (that does not require availability) or if it is deemed that interrupting ALMP participation to take up a job offer will be detrimental to future job prospects. ${ }^{12}$

22. Items 4, 5 and 6 describe so-called "suitable work" criteria. Legislation or guidelines typically outline under what circumstances an unemployment benefit recipient is allowed to refuse a job offer without sanction. The criteria may relate to the characteristics of the job (e.g. the occupation, wage, geographical location or working conditions) or the circumstances facing the unemployed person which give them good cause to refuse the job offer (e.g. family responsibilities or health problems). Suitable work criteria often influence the types of job vacancies to which unemployment benefit recipients are referred by the PES, but also apply in theory to self-directed job search. However, the PES normally has no information about outside job offers made to benefit recipients. ${ }^{13}$ The enforcement of suitable work criteria with regard to self-directed job search is only possible to a limited extent, when the placement service or benefit administration requires reporting of contacts with employers (some documentation of these procedures is provided here under Item 7).

23. Item 4 describes the circumstances in which an unemployed person can refuse a job that is not in the same occupational area as their previous work experience or training. New jobseekers may be able to limit their job search to their own occupational area for the initial period of unemployment but are typically obliged to accept other jobs after an extended period of unemployment. Item 5 describes the maximum

9. The categories were assigned so that the modal/median value in 2011 (12 months) was given a score of 3.

10. The definitions of "good reason" and "for cause" vary across countries.

11. In some cases, benefit suspensions result in a deferral of benefits, without reducing the overall duration of benefits to which the unemployed person is eligible. In other cases, benefit suspensions are subtracted from the total duration and have the effect of reducing benefit duration. However, no distinction is typically made between these two outcomes in either the information given in the tables in Annex B or the scores derived from them in the figures that follow.

12. Note that the definition of availability for work used for determining eligibility for ordinary unemployment benefit recipients is not included in the information presented in this paper, although countries have provided some information of this kind under Item 6.

13. Council of Europe (2009) reports that employers are usually not obliged to inform the PES if an unemployed person referred to them by the PES refuses a job offer, although in certain countries, the PES checks with employers about why a referred jobseeker was not employed. In any case, less than half of all job vacancies are notified to the PES in most European countries. 
commuting time which is deemed suitable for unemployed persons taking up a new job. If the commuting time is longer than that allowed, the unemployed person can refuse the job offer without sanction. In some cases, unemployed persons are required to move to a new location in order to take up a job offer. In other cases, the limit is not explicit but refers to work within the same town, suburb or region as the benefit recipient's home. In these cases, it is assumed that the limit is less than two hours per day. Travel times are typically calculated based on using public transport, although the use of private transport may be required in areas where public transport is not available.

24. Item 6 describes factors other than occupational or geographical mobility that are taken into account when determining whether a job offer is suitable for an unemployed person. To enable some objectivity in determining the range of criteria applied, six types of reasons are examined: (i) family or personal reasons (e.g. caring responsibilities, spouse's work, lack of child care, etc.); (ii) own health or disability; (iii) if the wage offered is lower than the unemployment benefit or the usual wage for that type of job; (iv) other working arrangements of the job (e.g. part-time, temporary contract, anti-social working hours, etc.); (v) moral or religious reasons; or (vi) if the job is to replace workers on strike or lockout. It is assumed that all countries require suitable jobs to have wages and working conditions consistent with legal requirements or applicable collective agreements and that certain types of work (e.g. prostitution) are not considered suitable work. Thus these criteria are not counted for the purposes of coding this item.

25. Item 7 relates to job-search monitoring and describes if and how often benefit recipients must prove that they have been actively searching for work. Benefit recipient may be asked to prove that they followed up on job referrals given by the Public Employment Service (PES) or equivalent private-sector job-placement providers. They may also have to prove independent job search, such as showing copies of job applications or statements from potential employers that the recipient has applied for an advertised job.

26. Items 8 and 9 describe the sanctions applied if unemployment benefit recipients breach jobsearch or ALMP participation requirements while in receipt of benefits. As for sanctions relating to voluntary unemployment (Item 2), sanctions for refusing job offers or ALMP placements can take the form of reductions or suspension of benefits. Item 7 describes the sanctions imposed if the unemployed person refuses a suitable job offer or refuses to participate in an ALMP for the first time, while Item 8 describes the sanctions imposed for multiple refusals of suitable job offers or ALMP participation.

27. The choice of weights when compiling a summary indicator is necessarily subjective. In the absence of strong evidence about the relative importance of various eligibility criteria in influencing unemployment outcomes, it is tempting to allocate equal weights to each item. However, Figure 1 shows that the items can be grouped into four categories, which can be used to guide the selection of weights. Each category reflects one aspect of eligibility policy (entitlement conditions; job-search and availability requirements; monitoring; sanctions), and the categories are themselves interesting for researchers and policy-makers. As will become clear in the sections that follow, different countries have adopted different mixes of eligibility criteria. A single indicator that includes all nine items will hide this substantial degree of heterogeneity in the policy mix adopted in different countries. Therefore it was decided to create four sub-indicators, which can then be aggregated into an overall summary indicator.

28. Because each sub-indicator comprises a different number of items, using equal weights to compile a summary indicator will increase the weight given to job-search and availability requirements and reduce the weight given to the other sub-indicators (particularly monitoring) in the summary indicator. To avoid this problem, each sub-indicator is given equal weight in the summary indicator and each item is given equal weight within its sub-indicator. The weights are shown in Table 1. Section 5 will examine the sensitivity of the indicator to the weights used. 
Table 1. Weights

\begin{tabular}{llc}
\hline Category/sub-indicator & Item & $\begin{array}{c}\text { Weight in } \\
\text { summary } \\
\text { indicator }\end{array}$ \\
\hline Entitlement conditions & 1. Employment and/or condition record & $1 / 4$ \\
& 2. Sanctions for voluntary unemployment & $1 / 8$ \\
\hline Job-search and availability & 3. Availability during ALMP participation & $1 / 8$ \\
\hline & 4. Demands on occupational mobility & $1 / 4$ \\
\hline & 5. Demands on geographical mobility & $1 / 16$ \\
\hline Monitoring & 6. Other valid reasons for refusing job offers & $1 / 16$ \\
\hline Sanctions & 7. Proof of job search & $1 / 16$ \\
\hline & 8. Sanctions for refusing job offers or ALMP placements & $1 / 4$ \\
\hline Sum of weights & 9. Sanctions for repeated refusal of job offers or ALMP placements & $1 / 4$ \\
\hline
\end{tabular}

\subsection{Data collection}

29. Data reflecting most aspects of eligibility criteria in place in 2011 were collected through a questionnaire sent to delegates to the OECD Employment, Labour and Social Affairs Committee and/or the Indicator Sub-Group of the European Commission's Social Protection Committee. Data for 1997 and 2003/04 were constructed using the descriptions from Ministry of Finance (1998) and Hasselpflug (2005), respectively, for the countries covered in those papers, based on the updated methodology described above. Additional information was taken from the descriptions of eligibility requirements and suitable work criteria in OECD (2007) and Council of Europe (2009). Questionnaire responses were summarised and coded by the OECD Secretariat and sent back to delegates to ensure that the summary accurately reflected the situation in each country. Delegates were also asked to verify that any changes in the indicator over time reflect actual policy or legal changes. Countries for which earlier data points could not be verified were excluded from the discussion of changes in the indicator over time.

30. Data for Item 1 (employment and contribution record) were compiled from descriptions in the country notes for the OECD Benefits and Wages database (www.oecd.org/els/workincentives). Data relate to the most recent information available for each country (2010 for all countries, with the exception of Turkey (2008)). ${ }^{14}$ Data on Item 1 for earlier years were taken from the 2004 (2005 for Estonia, Lithuania, Malta and Slovenia) and 1997 country notes.

31. Responses relate to eligibility criteria for the most commonly-received type of unemployment benefit in each country. Respondents were asked to answer based primarily on unemployment benefit legislation and/or official guidelines to the legislation, but also to check the operational practices of the employment service or benefit administration where necessary. In the United States, eligibility criteria are set primarily in state-level legislation and guidelines. As a result, some criteria and sanctions differ across states. In this situation, the coding reflects the median situation in the seven largest states by share of unemployment in January 2011 (California, Florida, Texas, New York, Ohio, Pennsylvania and Illinois). Together, these seven states account for almost half of the US labour force. ${ }^{15}$

14. Country notes for 2010 are forthcoming on the website.

15. According to seasonally-adjusted data from the Bureau of Labor Statistics' Current Population Survey of January 2011. 


\section{4. $\quad$ Eligibility criteria in 2011}

32. This section describes eligibility criteria for unemployment benefits in force in 36 OECD and/or EU member countries in early 2011, and provides a score between one (least strict) and five (most strict) for the strictness of each item, based on the revised coding framework explained in Section 3. Detailed tables describing eligibility criteria in each country are at Annex B.

\subsection{Entitlement conditions}

33. This section describes entitlement conditions, encompassing the employment/contribution record required to obtain access to the primary form of unemployment benefits (usually unemployment insurance), and sanctions for voluntary unemployment. As measured by the indicator, entitlement is most limited in Italy, Portugal and Turkey, where contribution and/or employment periods of two years or more coexist with strict sanctions for voluntary unemployment (Figure 2). By contrast, Australia and New Zealand require no contribution/employment record and impose relatively light sanctions for voluntary unemployment, while Norway, Austria, Denmark, Cyprus and the Czech Republic all have relatively light entitlement conditions once sanctions for voluntary unemployment are taken into account.

Figure 2. Strictness of entitlement conditions

Indicator scored from 1 (least strict) to 5 (most strict)

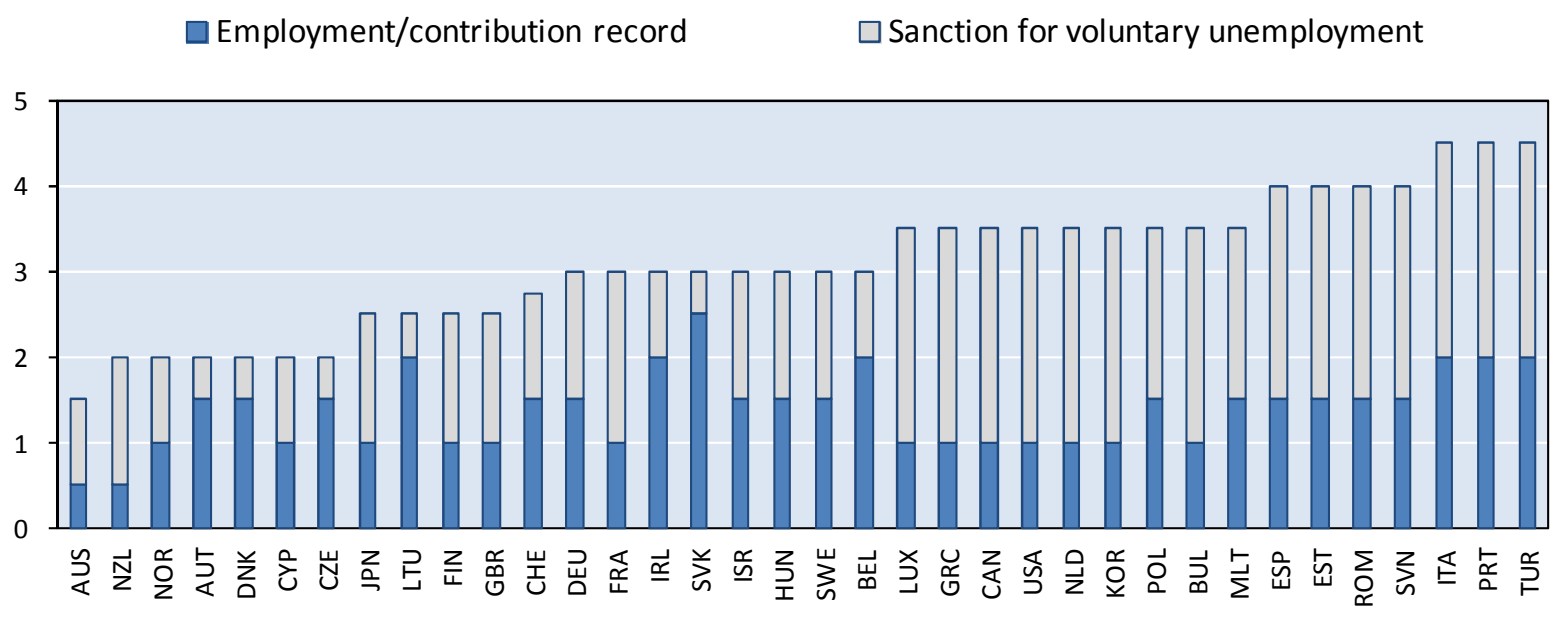

Item 1: Employment/contribution record

34. Unemployment benefits in Australia and New Zealand are non-contributory (financed out of general taxation revenue) and therefore not dependent on previous employment history. ${ }^{16}$ Among those countries with contributory schemes, less than a year of employment and/or contribution is required in Bulgaria, Canada, Cyprus, Finland, France, Greece Japan, Korea, Luxembourg, the Netherlands, Norway, Slovenia, the United States and the United Kingdom. More than one year is required in Belgium, Ireland, Italy, Portugal and Turkey and three years in the Slovak Republic. In the remaining countries, around 12 months of employment and/or contributions are required (see Annex Table B1 for full details).

16. However, a household-level means- and assets-test applies to new applicants for unemployment benefits. 


\section{Item 2: Sanctions in case of resignation from previous job}

35. Sanctions for voluntary unemployment vary widely across countries (see Annex Table B2 for full details). Workers in Canada, Estonia, Greece, Italy, Korea, Luxembourg, the Netherlands, Portugal, Romania, Spain, Turkey and the United States who are voluntarily unemployed are not eligible for unemployment benefits. By contrast, in the Slovak Republic and Lithuania there is no penalty for voluntary unemployment, although in Lithuania workers who are dismissed for misconduct (as opposed to those who resign voluntarily) are subject to a three month waiting period. In Bulgaria and the Czech Republic, benefits are reduced for those who are voluntarily unemployed. In other countries, benefits are delayed or suspended as a result of voluntary unemployment for a period ranging from three weeks in Denmark to around six months in Malta and Poland.

\subsection{Job-search and availability requirements}

36. This section describes availability requirements for ALMP participants and suitable work criteria. Figure 3 shows the overall strictness of these requirements as measured by the indicator. Norway, Germany and Denmark allow unemployment benefit recipients few valid reasons for refusing job offers and generally require ALMP participants to be available for work. In contrast, Korea, Belgium, the United States and Greece allow refusals of job offers for a broad range of reasons and do not require availability during most ALMPs.

Figure 3. Strictness of job-search and availability requirements

Scored from 1 (least strict) to 5 (most strict)

$\square$ Availability during ALMPs $\quad \square$ Occupational mobility Geographical mobility $\quad \square$ Other suitable work criteria

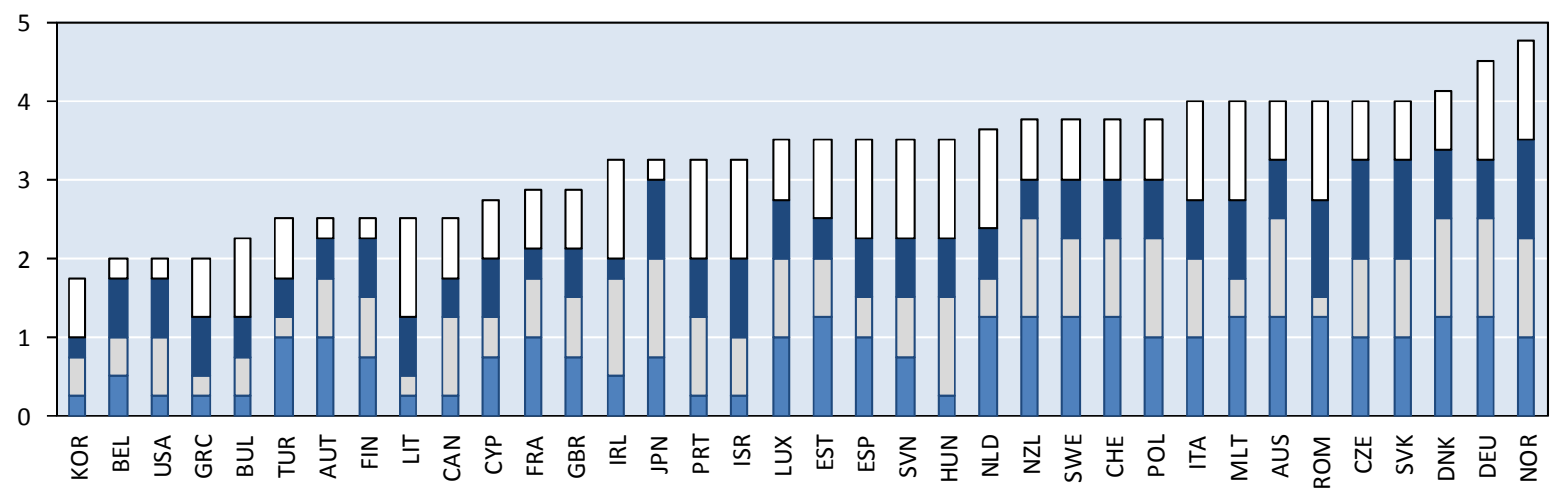

Item 3: Availability for work during participation in ALMPS

37. In Australia, Denmark, Estonia, Germany, Malta, New Zealand, Romania, Sweden and Switzerland, ALMP participants must remain available and actively looking for work. Ongoing work availability, but not necessarily job search, is required in Austria, the Czech Republic, Italy, Japan, Norway, Poland, Spain and Turkey, while in the Slovak Republic, job search is only required during the last two months of participation in programmes lasting longer than two months. Some countries, including Belgium, Cyprus, Finland, Luxembourg, Slovenia and the United Kingdom, exempt participants in some ALMPs (most commonly training programmes) from being available for work. In Ireland, full-time ALMP participants are exempted from availability requirements, but part-time participants are expected to be actively looking for work. ALMP participants are not required to be available for work in Bulgaria, Canada, Greece, Hungary, Israel, Korea, Lithuania, Portugal and the United States (see Annex Table B3 for full details). 


\section{Item 4: Demands on occupational mobility}

38. In Australia, Denmark, Germany, Hungary (from January 2011), Ireland, Japan, New Zealand, Norway and Poland, unemployment benefit recipients are required to accept any job that they are capable of doing, regardless of their previous occupation. This requirement applies also to those aged under 35 years in Israel and under 30 years in Switzerland from April 2011. One country mentions that the PES may, in practice, avoid referring unemployment benefit recipients to job vacancies for which they are distinctly over-qualified. Canada, the Czech Republic, Italy, Luxembourg, Portugal, the Slovak Republic and Sweden do not have explicit occupational mobility requirements, but the unemployment benefit recipient's previous occupation, skills and/or education are taken into account.

39. At the other end of the spectrum, jobseekers in Greece, Lithuania, Romania and those aged over 50 in Belgium can refuse job offers in other occupational areas indefinitely without sanction. In Turkey, jobseekers specify up to ten occupations in which they will accept work and can refuse job offers outside these occupations indefinitely. In the remaining countries, unemployment benefit recipients can refuse job offers outside their previous occupation for a limited period at the beginning of the unemployment spell, with requirements becoming stricter as the duration of unemployment lengthens. In some cases, the PES may decide that the jobseeker's previous occupation provides too few job opportunities and require jobseekers to expand their search to a wider group of occupations earlier (see Annex Table B4 for full details).

\section{Item 5: Demands on geographical mobility}

40. Most countries set a time or distance limit, above which benefit recipients are justified in refusing a job offer (see Annex Table B5 for full details). In Romania and the Slovak Republic, unemployment benefit recipients must be willing to move to take up a job offer, but are offered relocation or commuting subsidies to do so. In Norway, recipients must also be willing to move in most circumstances, but can provide a valid reason for refusing a job offer that requires relocation, such as family responsibilities. In Israel, Japan and, after three months of unemployment, Denmark, long travel times are required. Less than four hours travel per day is required in all other countries, with some requiring less than two hours per day. ${ }^{17}$ In France, geographical mobility requirements apply only after six months of unemployment. In several countries (e.g. Australia, Hungary, Lithuania, Portugal, Slovenia) required commuting times are shorter for jobseekers with significant family responsibilities, or in the case of Belgium and Luxembourg, due to health or age considerations. On the other hand, longer commuting times may be required if jobseekers live in traditional commuting areas or regions where people typically commute long distances (e.g. Denmark, United States). In the Netherlands and the United Kingdom, longer commuting distances are required after prolonged spells of unemployment.

\section{Item 6: Other valid reasons for refusing job offers}

41. Austria, Belgium, Finland, Japan and the United States accept a relatively large array of reasons for refusing job offers, while only limited reasons are accepted in Germany, Hungary, Ireland, Israel, Italy, Lithuania, the Netherlands, Norway, Poland, Portugal, Romania, Slovenia and Spain. Several countries (Austria, Bulgaria, Czech Republic, Estonia and Portugal) accept fewer reasons for refusing job offers as the unemployment spell lengthens. In Israel, stricter criteria apply to younger jobseekers (see Annex Table B6 for full details).

17. In Malta, this item is coded as four, even though most areas can be reached within one hour. There are no restrictions on geographical mobility other than that jobseekers are not required to move to another island to take up work. 
42. The most commonly-accepted reasons relate to personal circumstances (such as caring responsibilities that may require work at particular hours or a lack of adequate child care) or health problems that may prevent the jobseeker from taking up particular types of work. However, if these types of reasons limit jobseekers from working at all, they will then typically be in breach of work availability requirements for unemployment benefits. Many countries also allow jobseekers to refuse job offers if the wage is lower than the unemployment benefit (Belgium, Finland, Hungary, Israel, Luxembourg, Portugal), lower than the unemployment benefit recipient's previous wage or a specific fraction thereof (Austria, Estonia, Sweden, Turkey), or lower than the usual wage for that job (Canada, Cyprus, Denmark, Japan, United States). In France and Germany, the required salary for a suitable job falls with the duration of unemployment.

\subsection{Job-search monitoring}

\section{Item 7: Proof of job-search activity}

43. Figure 4 shows that job-search monitoring, as measured by the indicator, is strictest in Australia, Portugal, the Slovak Republic and the United Kingdom (see Annex Table B7 for full details). Unemployment benefit recipients are required to prove job-search activity fortnightly or more often in Australia, Portugal, the Slovak Republic (for most unemployed) and the United Kingdom, and monthly in Austria, Estonia, France, Japan, Korea, Lithuania, Malta, Romania and Switzerland. At the other end of the scale, jobseekers in Bulgaria, Cyprus, Greece, Hungary, Israel, Italy, Poland, Spain, Sweden and Turkey are not required to prove job search. Among these countries, Bulgaria, Hungary, Spain and Turkey mention (and it is probably true for several others) that jobseekers must prove they have followed up on referrals to job vacancies from the PES, while in Cyprus, the PES follows up on referrals with employers. In Canada, jobseekers are required to confirm their availability for work each fortnight, but evidence of job-search activity is only needed if requested. Likewise, the unemployed in most states of the United States are required to keep records of job-search activities, which must be produced upon request.

Figure 4. Strictness of job-search monitoring

Scored from 1 (least strict) to 5 (most strict)

Proof of job search

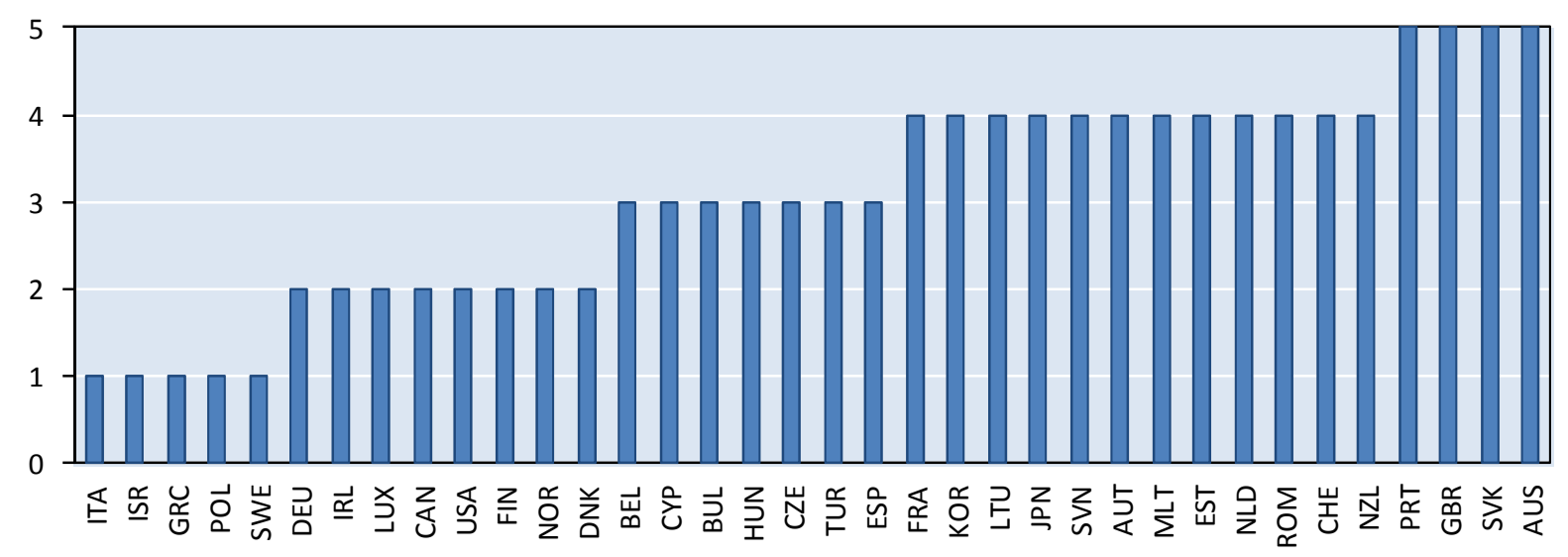

44. With the introduction of individualised counselling and job-seeking plans, it has become somewhat more difficult to identify the frequency with which benefit recipients must prove job-search activity. In several countries, benefit recipients work with a counsellor to develop an individual plan, which typically outlines the various activities that the benefit recipient will undertake to help them find 
work. The activities could include applying for jobs, writing a CV, participating in a training programme or undertaking volunteer work or subsidised work experience. The plan is assessed periodically to ensure that the benefit recipient is fulfilling their obligations, but often the frequency of reporting and type of proof needed is determined on a case-by-case basis. This model is followed the Netherlands and Slovenia, where the frequency with which job search must be proven is determined in the action plan. In Denmark, Finland, Germany and Norway, jobseekers are not generally required to prove job-search activities as part of their action plan, but in some countries may be required to do so in certain circumstances, such as if they have not adequately searched for work in the past. In Poland, job-seekers with specialised needs are required to have an action plan after 180 days of unemployment which may include a requirement to prove job-search activity. Individual action plans may also be created for other jobseekers. In Belgium, intensive interviews, which may require proof of job search, are held only after a relatively long period of unemployment (15 months for jobseekers aged under 25 and 21 months for older jobseekers) and at relatively long intervals (every 16 months if search efforts are deemed adequate or every four months if search efforts are inadequate after the first interview). Jobseekers are also required to report on the outcome of vacancy referrals by the PES.

\subsection{Sanctions}

45. Unemployment benefit recipients are typically subject to sanctions if they refuse a suitable job offer (as defined under Items 4, 5 and 6) or refuse to participate in ALMPs without a good reason. Figure 5 shows the strictness of sanctions for refusing a suitable job offer or ALMP participation as measured by the indicator. Sanctions are strictest in the United States, Greece, Turkey, Slovenia, Romania, Portugal, the Slovak Republic, Luxembourg, Italy and Ireland, where refusing job offers result in complete suspension of benefits. In Japan and the Netherlands, breaches result in far shorter suspensions, typically lasting for 12 months.

Figure 5. Strictness of sanctions

Scored from 1 (least strict) to 5 (most strict)

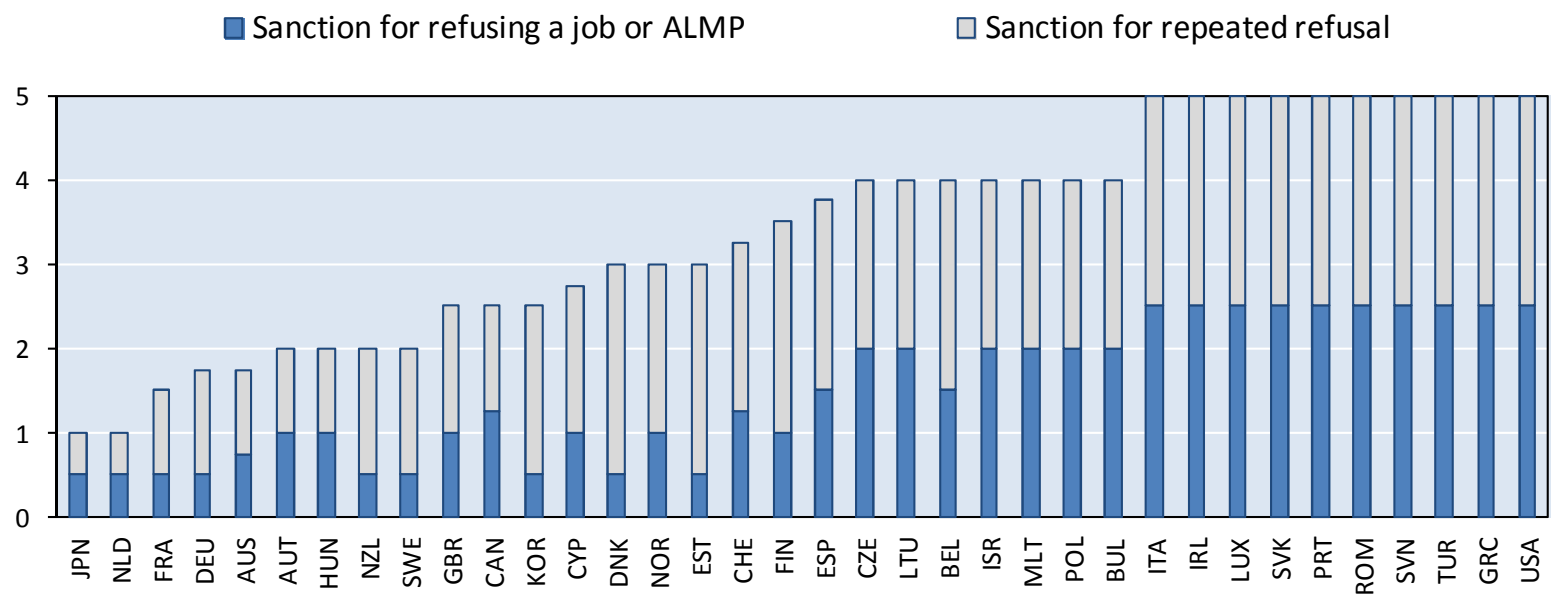

\section{Item 8: Sanctions for refusing job offers or ALMP participation}

46. Greece, Ireland, Italy, Luxembourg, Portugal, Romania, Slovak Republic, Slovenia, Turkey and the United States suspend benefits completely for an initial refusal of a job offer or ALMP placement (see Annex Table B8 for full details). Suspensions are relatively short (one month or less) in Denmark, Estonia, Germany, Japan and Korea. In several countries, benefits are reduced for a fixed period (France, the 
Netherlands, Sweden) or until the jobseeker complies with the requirement (New Zealand), rather than suspended. By contrast, relatively long benefit suspensions apply in Bulgaria, Israel, Lithuania and Poland.

\section{Item 9: Sanctions for repeated refusal of job offers or ALMP participation}

47. Many countries have escalating sanctions for unemployment benefit recipients who repeatedly refuse suitable job offers or to participate in ALMPs without good reasons (see Annex Table B9 for full details). ${ }^{18}$ Aside from those countries that suspend benefits completely following the first refusal, Belgium, Denmark, Estonia and Finland suspend benefits completely following a second refusal and Sweden and Spain following a third refusal. The sanction is generally the same each time a job offer or ALMP placement is refused in Bulgaria, Canada, the Czech Republic, Hungary, Israel, Japan, Lithuania, Malta and the United Kingdom. However, in cases where the suspension of benefits for the first refusal is relatively long and the overall period of benefits is reduced as a result of the sanction, subsequent refusals may lead benefit recipients to exhaust their entitlement completely even if the sanctions are not escalating by design.

\section{Overall strictness of eligibility criteria}

\subsection{Summary indicator for 2011}

48. Figure 6 shows the overall strictness of behavioural eligibility criteria as measured by the indicator. The indicator refers to the situation in 2011 for all countries. Eligibility criteria and sanctions are strictest in Portugal, Romania, the Slovak Republic and Slovenia and are least strict in Sweden, Cyprus, Austria, Finland and Canada. The countries with the strictest eligibility criteria tend to have strict rules in all four sub-indicators. However, there is considerable cross-country variation in the relative importance of the different sub-indicators. Reassuringly, neither the scores nor ranks are affected greatly by the use of alternative weighting schemes (see Box 1).

18. In countries which have different sanctions for the second and subsequent refusals, the score given reflects the average score for the second and third refusals. 


\section{Figure 6. Overall strictness of eligibility criteria}

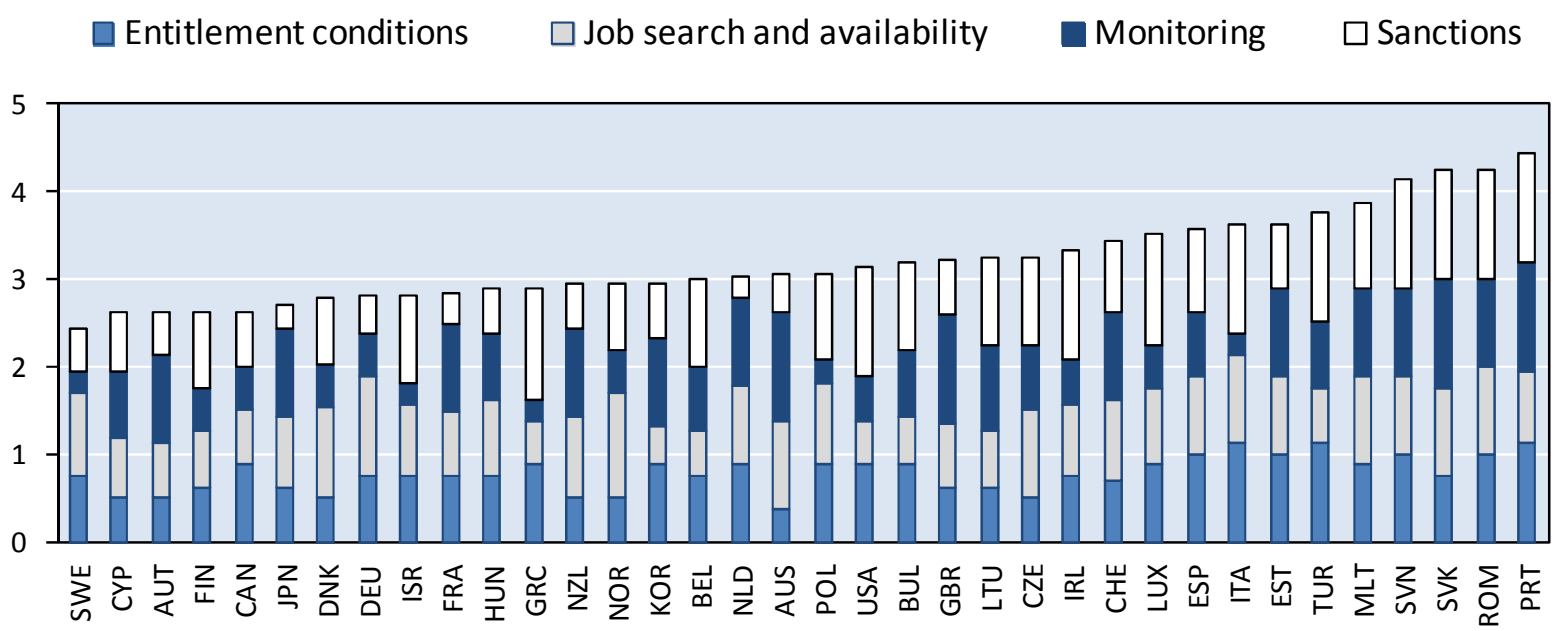

\section{Box 1. How much difference do the weights make?}

As discussed in Section 3.2, the summary indicator is calculated by taking a weighted average of the nine items, with the weights chosen so that the sub-indicators have equal weight in the summary indicator and the items have equal weight within their respective sub-indicators. The figure below shows that if the indicator had been constructed given equal weight to all nine items, the scores and ranks would have changed only slightly. The cross-country correlation between the two indicators is very high and statistically significant.

\section{Correlation between indicator using different weights}

Equal weights

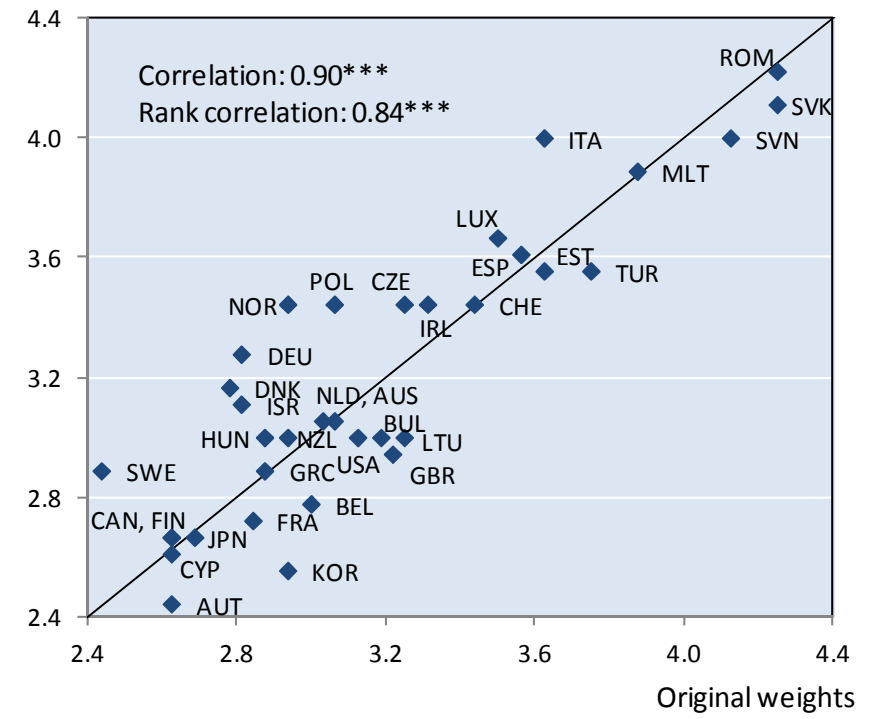

Note: ${ }^{* * *}$ indicates that correlation is statistically significant at the $1 \%$ level.

The change in weights from using equal weights rather than the original weights is not trivial. For example, the weight on Item 7 (job-search reporting) when using equal weights is less than half of that when using the original weights, while the weights on Items 3-6 (job-search and availability requirements) are more than 1.5 times larger. The additional subjectivity introduced by having non-equal weights for the items does not appear to outweigh the value of having sub-indicators that reflect economically-meaningful categories that allow us to examine the policy mix used by different countries. However, weighting analysis does not assess the accuracy of the indicator values themselves. 


\section{2. $\quad$ Changes in the summary indicator since 1997}

49. Using information from Ministry of Finance (1998), Hasselpflug (2005) and the OECD Benefits and Wages database, it is possible to reconstruct the indicator and sub-indicators for several countries for 1997 and 2003/04. This provides some insight into how the strictness of eligibility criteria have changed over time. However, some caution should be exercised when interpreting these results, given they are based on a retrospective recoding of information relating to the situation more than a decade ago, in some cases. ${ }^{19}$ In addition, the indicator only captures changes in the aspects of eligibility criteria that are covered by the indicator. Other policy changes that may have affected the strictness of eligibility criteria, in law or in practice, are not reflected in the discussion below.

50. Figure 7 shows how the strictness of behavioural eligibility criteria and sanctions has changed between 1997 and 2003/04 in the countries for which data for earlier years are available. ${ }^{20}$ Most changes have resulted in stricter eligibility criteria, with most of the increase in strictness accounted for by stricter job-search and availability criteria and monitoring. In contrast, most changes to relax eligibility criteria were made by reducing the severity of sanctions (including those for voluntary unemployment which affect entitlement conditions). Policy changes that affected the value of the summary indicator occurred in the following countries:

- Australia: Between 1997 and 2003/04, job-search requirements for ALMP participants were introduced. Between 2003/04 and 2011, the sanctions for voluntary unemployment or refusing a job offer were increased. The monetary sanction for refusing ALMP participation was removed and replaced with a requirement to attend an interview or complete a job-seeking diary or individual action plan.

- Austria: Requirements to prove job search monthly and be available for work during ALMP participation were introduced between 1997 and 2003/04. ${ }^{21}$

- Belgium: The sanction for voluntary unemployment or refusing a suitable job fell from 26-52 weeks in 1997 to 4-52 weeks in 2003/04 (typically 5-9 weeks for voluntary unemployment and $10-14$ weeks for refusing a job offer). ${ }^{22}$

19. The data presented in this section on changes over time have been verified by national experts. Some countries that were included in the earlier studies by Ministry of Finance (1998) and Hasselpflug (2005) were not included in this section because it was not possible to verify data points for 1997 and 2003/04 with national experts.

20. Changes are not shown for New Zealand or Canada in Figure 7 because data are only available for 1997 and not for 2003/04. Between 1997 and 2011, New Zealand tightened requirements for reporting jobsearch activity and availability during ALMP participation. In 1997, Canada required participants in jobcreation programmes to be available for work, but in 2011, ALMP participants are not required to be available.

21. In 2005, Austria clarified rules on suitable work by setting out the requirements explicitly (e.g. specifying travel time and wages relating to occupational mobility requirements) and linking some aspects (e.g. child care responsibilities) to other statutory requirements. However, these changes were not incorporated into the indicator as an increase in the strictness of rules as their purpose was to clarify rules that were already used in practice.

22. Belgium also introduced individual action plans with possible checks on job-search activity after 15 months of unemployment (for those aged under 25) or 21 months of unemployment (for those aged over 25 ) in 2004. However, because these checks occur only after very long periods of unemployment, the indicator was not changed from the previous score of 2. 
- Czech Republic: In 2003/04, the sanction for refusing a job offer was a complete suspension of the unemployment benefit. In 2011, the benefit is suspended for six months. For most unemployed, this change has no effect as the maximum duration of the benefit is six months or less. However, jobseekers aged over 50 have benefit durations longer than six months. Between 2003/04 and 2011, the definition of suitable work was changed to allow jobseekers to refuse jobs with wages below a certain level or with temporary contracts of less than three months.

- Denmark: Between 1997 and 2003/04, Denmark introduced a requirement to be actively searching for work during ALMP participation, removed an exemption from occupational mobility in the first six months of unemployment, removed the upper limit from travel time after six months of unemployment, and reduced slightly the sanction for voluntary unemployment from 5 weeks to 3 weeks.

- Estonia: In 2003/04, the definition of suitable work took into account the unemployed person's occupational qualifications and previous work experience, among other factors. In 2011, this applies only in the first 20 weeks of unemployment. After 20 weeks, the unemployed must accept all job offers regardless of their occupation or qualifications, as long as the wage is above the unemployment benefit. Also in 2011, the unemployed must accept jobs as long as they require less than two hours of daily travel time and travel costs are less than $15 \%$ of the monthly wage. In 2003/04 there were no requirements on geographical mobility.

- Finland: In 1997, no proof of job search was required. In 2003/04 and 2011, jobseekers can be required to show proof of job search under their individual action plan. In some cases, ALMP participants in 2011 are not required to be available for normal work, whereas in earlier years job availability was generally required. The sanction for refusing a suitable job was also lengthened between 1997 and 2003/04.

- Malta: In 2003/04, the unemployed could refuse jobs outside their occupational area indefinitely. In 2011, they can only refuse job offers outside their occupational area for the first 12 months of unemployment.

- Netherlands: The introduction of individual agreements between 2003/04 and 2011 changed the frequency of reporting job-search activities for some jobseekers. Sanctions for refusing a job offer were substantially reduced between 2003/04 and 2011. In 2003/04, refusal led to a complete suspension of benefits, whereas in 2011, the first and subsequent refusals result in a $25 \%$ and $50 \%$ reduction in benefits for four months, respectively. Between 1997 and 2003/04, health and social reasons were removed as acceptable reasons for refusing suitable work.

- Portugal: Between 1997 and 2003/04, a requirement to report bi-monthly to prove job-search activity was introduced. In 1997 and 2003/04, there were no explicit requirements for geographical mobility, but in 2011, suitable work is defined as that which does not require travel time of more than $25 \%$ of working time in most cases. Portugal changed the employment conditions for eligibility for unemployment benefit from 540 days in 1997 to 270 days in 2003/04 to 450 days in $2011 .^{23}$

- Slovenia: Between 2003/04 and 2011, a requirement was introduced that the unemployed accept jobs at a lower level of education than their previous job after three months of unemployment.

23. A temporary change to 365 days was introduced for a short period in 2009. 
- Sweden: In 1997 and 2003/04, benefit recipients could restrict their job search both occupationally and geographically during the first 100 days of unemployment. In 2011, the 100 day limit was removed, so that suitable work takes into account the skills and qualifications of the unemployed person on a case-by-case basis, and up to three hours travel per day is required to take up suitable work. Sanctions for refusing a suitable job were also reduced from a 60 benefitday suspension in 1997 to a 25\% reduction for 40 benefit-days in 2003/04 and 2011. In 1997, the sanction for a second refusal was complete suspension of benefits, whereas in 2003/04 and 2011, a second refusal results in a $50 \%$ reduction for 40 benefit-days, with benefits suspended indefinitely only after a third refusal.

- United Kingdom: The requirement to look for work within a one-hour radius of home was extended between 2003/04 and 2011 to require job search within a 1.5-hour radius after 13 weeks of unemployment. In late 2010, changes to contribution requirements for National Insurance increased the period of contribution for most unemployed.

Figure 7. Changes in the strictness of eligibility criteria, 1997-2011

$\square$ Entitlement conditions $\square$ Job search and availability $\quad$ Monitoring $\square$ Sanctions

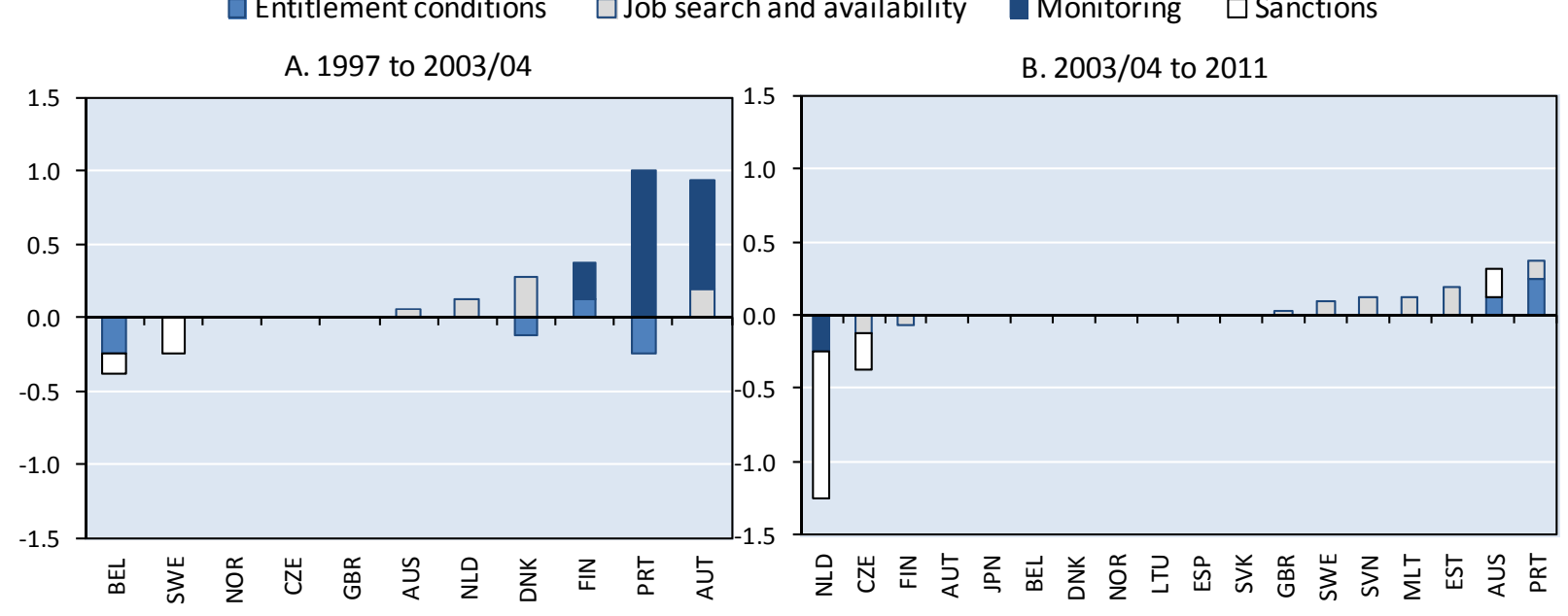

\subsection{Eligibility criteria, benefit generosity and ALMP expenditure}

51. Eligibility criteria are only one dimension of unemployment benefit schemes. One of the purposes of constructing an indicator of eligibility criteria is to be able to supplement existing data sources that describe other aspects of unemployment benefit schemes to provide a more comprehensive picture of how such schemes vary across countries and over time. Table 2 shows the cross-country correlation between the summary indicator and sub-indicators of the strictness of eligibility criteria and other features of unemployment benefit schemes. The summary indicator is significantly negatively correlated with ALMP expenditure, notably PES and benefit administration and training, and with the generosity of benefits, although these correlations are not statistically significant. However, using the summary indicator hides some important heterogeneity in the relationships between the sub-indicators and other features of unemployment benefits.

52. The sub-indicators are generally not correlated with each other (with the exception of the indicators for entitlement conditions and sanctions, which are positively correlated). However, they are correlated with other features of unemployment benefit schemes. Countries with stricter entitlement conditions tend to have shorter duration of benefits and spend less on the PES, benefit administration and 
training programmes for the unemployed. Countries with stronger sanctions also spend less on ALMPs, notably PES and benefit administration. Strict job-search and availability requirements coexist with more generous benefits, measured as the initial net replacement rate.

Table 2. Correlation between eligibility criteria and other features of unemployment benefits

\begin{tabular}{|c|c|c|c|c|c|}
\hline & $\begin{array}{c}\text { Entitlement } \\
\text { conditions }\end{array}$ & $\begin{array}{c}\text { Job search } \\
\text { and availability }\end{array}$ & Monitoring & Sanctions & $\begin{array}{l}\text { Summary } \\
\text { indicator }\end{array}$ \\
\hline Entitlement conditions & 1 & & & & $0.61^{* * *}$ \\
\hline Job search and availability & -0.12 & 1 & & & 0.23 \\
\hline Monitoring & -0.09 & -0.10 & 1 & & $0.42^{* * *}$ \\
\hline Sanctions & $0.52^{* * *}$ & -0.07 & -0.17 & 1 & $0.69^{* * *}$ \\
\hline Initial net replacement rate of unemployment benefits & -0.05 & $0.28^{*}$ & -0.13 & -0.10 & -0.05 \\
\hline Maximum duration of unemployment benefits & $-0.36^{* *}$ & 0.13 & 0.11 & -0.21 & -0.16 \\
\hline Net replacement rate averaged over 5 years & $-0.36^{* *}$ & 0.21 & 0.05 & -0.27 & -0.20 \\
\hline ALMP expenditure per unemployed person & -0.26 & 0.14 & -0.23 & $-0.33^{*}$ & $-0.38^{* *}$ \\
\hline PES and benefit administration & $-0.35^{\star *}$ & 0.24 & -0.01 & $-0.50^{* * *}$ & $-0.35^{\star *}$ \\
\hline Training & $-0.30^{*}$ & 0.06 & -0.23 & -0.19 & $-0.34^{* *}$ \\
\hline Job creation & -0.05 & -0.18 & 0.03 & -0.19 & -0.19 \\
\hline
\end{tabular}

Source: Data on unemployment benefit generosity are taken from the OECD Tax and Benefit database. Data on ALMP expenditure are taken from the OECD and Eurostat Labour Market Programme databases.

\section{Limitations of the indicators}

53. The correlation analysis in the previous section highlights the fact that different countries operate unemployment benefit schemes with vastly different mixes of rules, monitoring effort, sanctions, generosity and ALMP spending. Existing indictors of the features of unemployment benefit schemes used in cross-country analysis (net replacement rates and ALMP expenditure) tend to be negatively correlated with the strictness of eligibility criteria, so do not necessarily present a full picture of the generosity of benefits or the 'activation' stance in each country, for which they are sometimes used as proxies. In this respect, the indicators presented in this paper provide a step towards having a fuller quantitative picture of the complexities of unemployment benefit systems. However, there are some clear limitations to the indicators that warrant further attention.

\subsection{Implementation and enforcement}

54. A key limitation of the indicator (and indeed of any indicator based on the strictness of legislation or regulations) is that it only reflects the strictness of rules as they are outlined in legislation or regulation, not how they operate on the ground. In countries where implementation or enforcement of rules is lax or where PES counsellors have significant freedom in interpreting rules or implementing sanctions, there could be a major difference between de jure and de facto strictness of eligibility criteria.

55. PES or employment counsellors often have considerable leeway in how they interpret formal rules and implement sanctions when rules are breached (Grubb, 2001; OECD, 2000). In countries with the strictest rules or toughest sanctions, the strictness may itself encourage counsellors to interpret the rules more generously to avoid imposing what they see as unreasonable requirements or hardships. Indeed, in Belgium, a reduction of the severity of sanctions for voluntary unemployment or for refusing a suitable job offer between 1997 and 2003/04 was accompanied by an increase in the number of sanctions issued of more than threefold since $2000 .^{24}$

24. Data on sanctions in Belgium are from the annual reports of the National Employment Office (ONEM). 
56. At first glance, sanction rates (i.e. some measure of the proportion of benefit recipients who receive a sanction) may appear to be a good candidate for measuring the enforcement of eligibility criteria. However, the incidence of sanctions reflects both enforcement effort and compliance. Thus, increased sanction rates over time in one country (while the rules that are being enforced stay unchanged) may reflect an increase in enforcement effort. In the Belgian case, the increase in sanction rates was concurrent with a push to improve guidance, follow-up and information exchange at the regional level. But, it is much harder to argue that cross-country differences in sanction rates accurately reflect differences in either enforcement or the strictness of eligibility rules when there are so many factors that could influence sanction rates that also vary across countries. Moreover, the discussion in Section 2 highlights an important role for sanctions as a threat, even if no sanctions are actually imposed. While enforcement effort will also influence the effectiveness of sanctions as a threat, it could be argued that enforcement effort (or the lack thereof) is not easily visible to many unemployed. In countries where a first or second offence results in complete suspension of benefits, the unemployed may be unwilling to chance their luck on lax enforcement. In this case, the existence of strict sanctions may be equally or more important than their actual imposition.

57. While it is difficult to measure enforcement effort directly, one option that would improve the reliability of the indicator with regards to enforcement would be to include more information about monitoring effort. Presumably, the imposition of sanctions requires some effort of monitoring compliance with job-search or availability requirements. The indicator currently includes only the frequency with which the unemployed are required to prove job search. Including additional information on other aspects of monitoring, such as the incidence of intensive interviews and whether the PES checks with employers and/or jobseekers on the outcomes of referrals to vacancies, could improve the effectiveness of the indicator in measuring enforcement effort.

\subsection{Limits to international comparability}

58. Other questions remain about the extent to which the items measured in the indicator are truly comparable across countries. Grubb (2001) and OECD (2000) discuss these issues in some detail. They highlight several difficulties in creating a reliable cross-country indicator of the strictness of eligibility for unemployment benefits. First, legislation may not be very specific on some of the issues addressed in the indicator. For example, legislation defining suitable work may be vague on whether non-standard types of work (e.g. part-time or temporary contracts) are suitable or include general statements about job-search requirements that are difficult to interpret. ${ }^{25}$ Second, the strictness of eligibility criteria may be a reflection of the general labour market situation, so using indicators of strictness to study labour market outcomes may generate results that reflect reverse causality. For example, in countries with buoyant labour markets a requirement for independent job search is less onerous than in a country where there are few vacancies.

59. Finally, the strictness of eligibility criteria depend in part on other features of unemployment benefit and social protection schemes. For example, the relevance of suitable work criteria may vary across countries depending on the use of direct referrals to job vacancies. Suitable work criteria may be used to determine which types of vacancies jobseekers are referred to but play little role when most job-search activity is independent, as it is difficult to monitor and assess whether independent job offers are suitable.

60. The interaction of different features of unemployment benefits may also affect the international comparability of sanctions. The strictness of sanctions, measured here as weeks of benefits lost, will depend also on the generosity of benefits. Temporary suspensions of benefits will have a greater cost, in terms of income loss, in countries where replacement rates are higher. Sanctions that involve a full

25. Grubb (2001) gives the example of German legislation that requires an unemployed person to use "all possible ways to end his joblessness". 
suspension of benefits are more costly in countries where benefits normally have a long duration and/or social assistance for those who are not eligible for unemployment benefits is less generous or non-existent.

61. To test whether the sanctions indicator is an accurate reflection of the strength of sanctions once the generosity of benefits is taken into account, an alternative indicator was constructed which estimates the income lost from receiving a sanction for refusing a job offer or ALMP placement, based on the severity of the sanction (measured in weeks using information in Tables 9 and 10) and the duration and initial replacement rate of primary unemployment benefits (using data from the OECD Benefits and Wages database). Two measures were constructed: the weeks of income lost (at the average wage) from receiving a sanction for a single refusal of a job offer or ALMP placement and the cumulative income loss after refusing a job offer or ALMP placement three times. To ensure consistency with the way the original sanctions indicator was constructed, these two measures were averaged to get an overall estimate of the number of weeks of income lost from sanctions.

62. The correlation between the sanctions indicator and the average weeks of income loss from receiving sanctions is shown in Figure 8. Generally, countries which receive a higher score on the sanctions indicator also have relatively high values for average weeks of income loss. Denmark, Belgium and Portugal are outliers because they have relatively long duration of benefits and sanctions can include the complete loss of benefits. This exercise provides some reassurance than the sanctions indicator represents a reasonably good estimate of the relative cost of sanctions, at least as measured by the alternative measure constructed here. However, it only takes into account income replacement from unemployment benefits. In many countries, social assistance (usually far less generous than unemployment benefits) plays an important role in providing income support for those who are not eligible for unemployment benefits or who exhaust their entitlement. This should be kept in mind when comparing the strictness of sanctions.

\section{Figure 8. Sanctions indicator and estimated income losses from sanctions}

Correlation between sanctions indicator and average weeks of income loss as a result of sanctions for refusing a job offer or ALMP placement

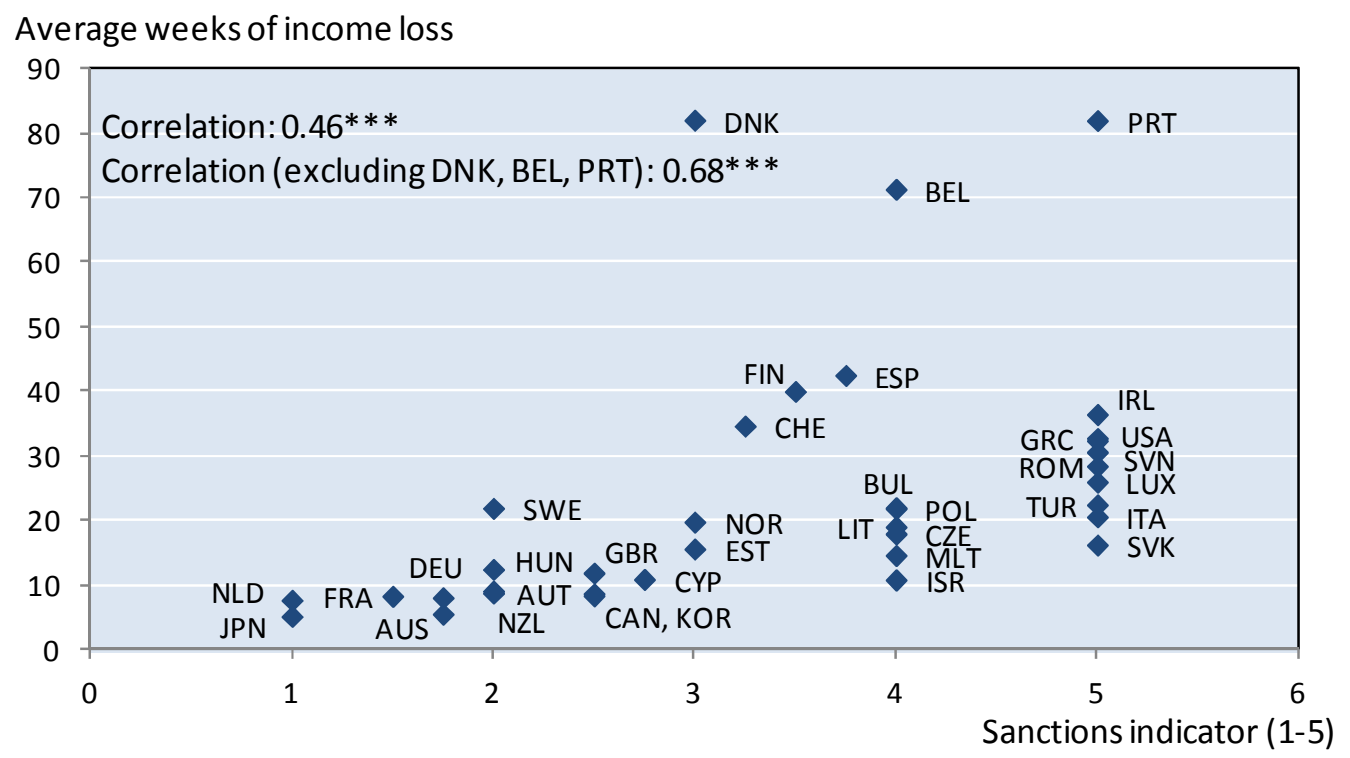

Note: ${ }^{* * *}$ indicates that correlation is statistically significant at the $1 \%$ level.

Source: Average weeks of income loss calculated using data on initial net replacement rate and maximum duration of unemployment benefits from the OECD Benefits and Wages database (www.oecd.org/els/social/workincentives). Sanctions indicator from Figure 5. 


\subsection{Missing items}

63. The indicator presented in this paper covers a range of eligibility criteria, but it is by no means exhaustive. Various studies provide evidence on additional legal or administrative requirements that affect eligibility for unemployment benefits but are not included in the indicator (Grubb, 2001; OECD, 2000, 2007). In some cases, their exclusion is because the information is too difficult to collect on a comparable, cross-country basis (e.g. actual implementation of suitable work criteria). However there are some good candidates for inclusion in future work that would broaden the scope of the indicator and/or add detail to some of the areas already covered, keeping in mind some of the limitations and difficulties in making international comparisons highlighted in the previous section. New items could include:

- Entitlement conditions: entitlement to benefits for temporary, seasonal or self-employed workers; employment conditions to be able to contribute to unemployment insurance (e.g. minimum number of hours, length of contract, etc.);

- Job-search and availability: availability requirements for ordinary unemployment benefit recipients; exemptions from availability requirements (e.g. for those seeking part-time work, with family responsibilities or undertaking volunteer work); number of job-search actions required; the existence and regularity of direct referrals from the PES;

- Monitoring: the regularity and timing of intensive interviews; whether there are formal checks with employers of the outcomes of referrals or independent job search;

- Sanctions: non-compliance with administrative requirements (e.g. not attending intensive interviews, failing to show proof of job-search activities); separate reporting of sanctions for refusing a suitable job and those for refusing ALMP participation (currently included jointly in Items 8 and 9); and

- Activation requirements: mandatory ALMP participation; creation of individual action plans.

64. It will no doubt be difficult to include all these items in a future update of the indicator. As highlighted in this section, it is sometimes difficult to determine exactly how rules or guidelines are implemented in practice in a way that makes cross-country comparisons meaningful. Other items (e.g. number of job-search actions required) vary significantly across different groups of jobseekers or are determined on a case-by-case basis. It may still be possible to include comparable measures by basing scores on a general case that would be the same in each country (e.g. for an adult jobseeker in the initial six months of unemployment), much as is the case for employment and contribution requirements reported in Section 4.1. Finally, it is likely that the information will have to be collected from delegates to OECD or EU committees dealing with these issues, much as has been done with the current indicator. It will be important to ensure that adding items to the indicator does not unduly increase the burden on respondents to ensure that future updates are timely and cover as many countries as possible.

65. However, these difficulties should not prevent future updates of the indicator being more ambitious in their scope. An example of adding two extra items for the monitoring sub-indicator (see Box 2) shows what might be possible, using information that is relatively-easy to collect and classify. The revised sub-indicator for monitoring strictness is correlated with the existing sub-indicator presented in this chapter, but adding more information allows greater differentiation between countries and reduces measurement errors. Some countries appear to be relatively less strict on monitoring if aspects other than the frequency of job-search reporting are taken into account. 


\section{Box 2. Expanding the indicator: an example for monitoring}

Using information provided in OECD (2007) and its electronic annex (at www.oecd.org/employment/outlook), it is possible to add two additional items on monitoring of job-search requirements to the existing indicator, which includes only Item 7 on the frequency of job-search reporting. The two items were scored as follows:

- Intensive interviews in the first year of unemployment: (1) No practice of intensive interviews; (2) Only initial intensive interview after registration, with no fixed schedule of further interviews in the first year; (3) 25 intensive interviews; (4) 6-11 intensive interviews; (5) 12 or more interviews.

- Reports on outcomes of job referrals: (1) No formal requirements; (2) Only if hiring occurs; (3) Report from jobseeker only; (4) Report from employer only; (5) Reports from jobseeker and employer.

The data from OECD (2007) relate to the mid-2000s and cover only some OECD countries. In some cases, insufficient data were available to calculate a score for all countries for which Item 7 for 2003/04 was available. Annex $\mathrm{C}$ provides the detailed information used to generate the score for the countries for which adequate information was available. A revised sub-indicator for monitoring was calculated by taking the unweighted average of the three items relating to monitoring. The chart below shows that the revised sub-indicator is significantly and positively correlated with the original sub-indicator presented in Section 4.4. of this paper.

This exercise suggests that it would be feasible to add new items on monitoring to a revised indicator in future updates. Some issues would need to be resolved, such as how to score intensive interviews in countries where the number of interviews is determined in the individual's action plan, by mutual agreement or varies substantially across individuals or regions for some other reason. One option is to collect data on a 'typical' unemployment benefit recipient. Another issue is to define intensive interviews more narrowly (e.g. face-to-face interviews lasting more than a certain minimum time) to make the data more comparable across countries and distinguish between intensive interviews and shorter, generally more frequent job-search reporting arrangements. Regarding reports on job referral outcomes, it would be important to understand the extent to which reporting requirements are actually undertaken and the form which report take. OECD (2007) discusses the cross-country comparability of information on these and other interventions in the unemployment spell in more detail.

\section{Correlation between existing and revised monitoring sub-indicator, 2003/04}

Score from 1 (least strict) to 5 (most strict)

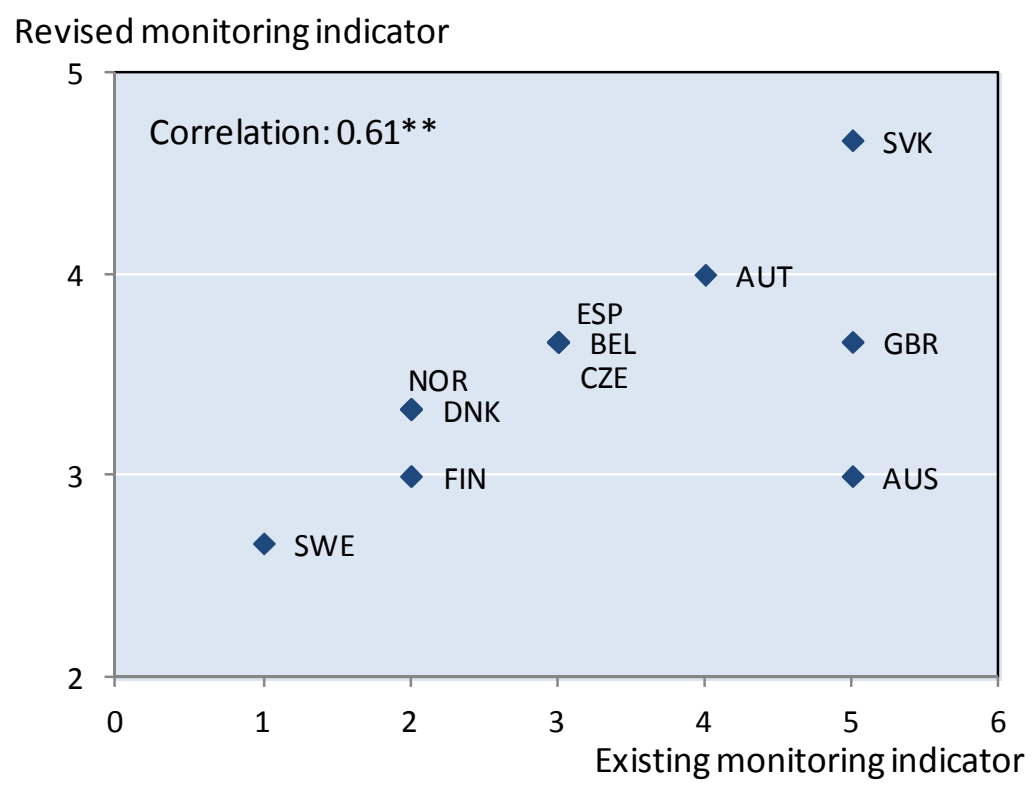

Note: ${ }^{*}$ indicates that correlation is statistically significant at the $5 \%$ level. 


\section{Conclusion}

66. In this paper, comparisons of the strictness of eligibility criteria for unemployment benefits in 36 OECD and/or EU member countries are presented using a new indicator and sub-indicators. Countries differ markedly in the mix of entitlement conditions, job-search requirements, monitoring and sanctions. The correlation between these new indicators and existing measures of the generosity of unemployment benefits suggests that empirical analysis and international comparisons of unemployment benefit schemes that neglect to take eligibility criteria into account fail to capture true cross-country heterogeneity. The existing theoretical and empirical literature suggests that the strictness of eligibility criteria could play an important role in influencing unemployment outcomes, perhaps offsetting the impact of benefit generosity in increasing unemployment duration.

67. To this end, the indicators represent a useful addition to existing empirical measures of the characteristics of unemployment benefit schemes. However, they are not without limitations, which include properly capturing implementation and enforcement and somewhat limited scope with regards to some features of eligibility criteria that may be important in influencing labour market outcomes. These limitations should be kept in mind when interpreting the information presented in this paper and/or using the resulting indicator and sub-indicators of the strictness of eligibility criteria. However, in the author's view, they do not justify abandoning efforts to measure eligibility strictness entirely.

68. Future work should focus on extending the indicators to include additional features of eligibility criteria that are not currently captured by the indicator, such as requirements for mandatory ALMP participation, or expand existing areas, such as monitoring. The indicators presented in this paper allow for comparison over time between the late 1990s and 2011. In order to facilitate empirical analysis using the indicators, a full time-series, incorporating the year when changes were made, would be desirable. Future updates that expand the scope of the indicator should attempt to also update the time series where possible. 


\section{ANNEX A: COMPARISON WITH DANISH FINANCE MINISTRY INDICATOR}

The indicator presented in the paper is based closely on that developed by the Danish Finance Ministry (Ministry of Finance, 1998; Hasselpflug, 2005), referred to below as the DFM indicator. The principle changes from the DFM methodology are shown in Table A1. and are outlined below:

- Item 1: Inclusion of a new item for employment and/or contribution record.

- Item 2 (DFM Item 6): Clarification that where benefits are reduced (rather than suspended), these items should be coded as $0-4$ weeks. The highest category is changed from "suspension of benefits" to "ineligible for benefits".

- Item 3 (DFM Item 2): Removal of references to activation benefits and creation of new categories for situations where participation in some or most ALMPs require job availability or where the unemployed must be available AND actively searching for jobs while participating in ALMPs.

- Item 4 (DFM Item 3): Creation of a new category for situations where the unemployed can refuse job offers in other occupational areas indefinitely.

- Item 5 (DFM Item 4): Clarification of hours ranges for required travel times.

- Item 6 (DFM Item 5): Creation of six types of reasons for which job offers can be refused and creation of three categories based on the number of types of reasons applying in each country.

- Item 7 (DFM Item 1): Creation of two new categories for situations where job-search activity can be checked upon request (such as if required by an individual action plan) and where job-search activity is only checked following a referral by the PES to a job vacancy.

- Item 8 (DFM Item 7): Clarification that where benefits are reduced (rather than suspended), these items should be coded as $0-4$ weeks.

- Item 9 (DFM Item 8): The same categories are used as in Item 8. If the sanctions are different for a second and subsequent rejections of a job offer or ALMP placement, the average of the sanctions for the second and third rejection is taken to determine the appropriate category. 
Figure A1. DFM and revised coding framework

\begin{tabular}{|c|c|c|c|}
\hline & & DFM categories & Revised categories \\
\hline \multirow{5}{*}{$\begin{array}{l}\text { ITEM 1: } \\
\text { Employment } \\
\text { and/or } \\
\text { contribution } \\
\text { record }\end{array}$} & 1 & \multirow{5}{*}{ Not included } & No employment or contribution requirements \\
\hline & 2 & & Less than six months \\
\hline & 3 & & Six to less than 12 months \\
\hline & 4 & & 12 months \\
\hline & 5 & & More than 12 months \\
\hline \multirow{5}{*}{$\begin{array}{l}\text { ITEM 2: } \\
\text { Sanctions in } \\
\text { case of } \\
\text { resignation } \\
\text { from previous } \\
\text { job }\end{array}$} & 1 & $0-4$ weeks & 0-4 weeks (including benefit reductions) \\
\hline & 2 & 5-9 weeks & $5-9$ weeks \\
\hline & 3 & 10-14 weeks & 10-14 weeks \\
\hline & 4 & More than 14 weeks & More than 14 weeks \\
\hline & 5 & Suspension of unemployment benefits & Ineligible for benefits \\
\hline \multirow{5}{*}{$\begin{array}{l}\text { ITEM 3: } \\
\text { Availability } \\
\text { during ALMP } \\
\text { participation }\end{array}$} & 1 & $\begin{array}{l}\text { No demand on job availability during } \\
\text { activation i.e. because the main part of } \\
\text { activation benefits is separated from the } \\
\text { unemployment system }\end{array}$ & $\begin{array}{l}\text { No demands on job availability during } \\
\text { participation in ALMPs }\end{array}$ \\
\hline & 2 & & $\begin{array}{l}\text { Participation in some ALMPs requires job } \\
\text { availability }\end{array}$ \\
\hline & 3 & $\begin{array}{l}\text { Generally the unemployed must be available } \\
\text { for work during activation, except from the } \\
\text { ALMPs where the received benefit is } \\
\text { separated from the unemployment benefit } \\
\text { system }\end{array}$ & $\begin{array}{l}\text { Participation in most ALMPs requires job } \\
\text { availability }\end{array}$ \\
\hline & 4 & & $\begin{array}{l}\text { The unemployed should always be available } \\
\text { for work while participating in ALMPs but are } \\
\text { not required to actively search for work }\end{array}$ \\
\hline & 5 & $\begin{array}{l}\text { The unemployed should always be available } \\
\text { for work under activation, however in some } \\
\text { instances the unemployed is not obliged to } \\
\text { actively search for jobs him/herself }\end{array}$ & $\begin{array}{l}\text { The unemployed should always be available } \\
\text { and actively searching for work while } \\
\text { participating in ALMPs }\end{array}$ \\
\hline \multirow{5}{*}{$\begin{array}{l}\text { ITEM 4: } \\
\text { Demands on } \\
\text { occupational } \\
\text { mobility }\end{array}$} & 1 & $\begin{array}{l}\text { The unemployed can refuse job offers in } \\
\text { other occupational areas for } 6 \text { months or } \\
\text { more }\end{array}$ & $\begin{array}{l}\text { The unemployed can refuse job offers in other } \\
\text { occupational areas indefinitely }\end{array}$ \\
\hline & 2 & $\begin{array}{l}\text { The unemployed can refuse job offers in } \\
\text { other occupational areas for less than } 6 \\
\text { months }\end{array}$ & $\begin{array}{l}\text { The unemployed can refuse job offers in other } \\
\text { occupational areas for a limited period of } 6 \\
\text { months or more }\end{array}$ \\
\hline & 3 & $\begin{array}{l}\text { No explicit reservations but the } \\
\text { unemployed's qualifications and the length of } \\
\text { the unemployment spell are taken into } \\
\text { account }\end{array}$ & $\begin{array}{l}\text { The unemployed can refuse job offers in other } \\
\text { occupational areas for a period of less than } 6 \\
\text { months }\end{array}$ \\
\hline & 4 & & $\begin{array}{l}\text { No explicit reservations but the unemployed } \\
\text { person's qualifications and the length of the } \\
\text { unemployment spell are taken into account }\end{array}$ \\
\hline & 5 & $\begin{array}{l}\text { No reservation, meaning that the } \\
\text { unemployed must accept all job offers that } \\
\text { he or she is capable of doing }\end{array}$ & $\begin{array}{l}\text { The unemployed must accept all job offers that } \\
\text { he/she is capable of doing }\end{array}$ \\
\hline \multirow{5}{*}{$\begin{array}{l}\text { ITEM 5: } \\
\text { Demands on } \\
\text { geographical } \\
\text { mobility }\end{array}$} & 1 & No demands on geographical mobility & No demands on geographical mobility \\
\hline & 2 & $\begin{array}{l}\text { The unemployed must accept a daily } \\
\text { transportation time of } 1-2 \text { hours per day }\end{array}$ & $\begin{array}{l}\text { The unemployed must accept a daily } \\
\text { transportation time of up to two hours per day }\end{array}$ \\
\hline & 3 & $\begin{array}{l}\text { The unemployed must accept a daily } \\
\text { transportation time of } 2-3 \text { hours per day }\end{array}$ & $\begin{array}{l}\text { The unemployed must accept a daily } \\
\text { transportation time of up to four hours per day }\end{array}$ \\
\hline & 4 & $\begin{array}{l}\text { The unemployed must accept a daily } \\
\text { transportation time of } 3-4 \text { hours per day }\end{array}$ & $\begin{array}{l}\text { The unemployed must accept a daily } \\
\text { transportation time of four or more hours per } \\
\text { day }\end{array}$ \\
\hline & 5 & The unemployed must be willing to move & The unemployed must be willing to move \\
\hline
\end{tabular}




\begin{tabular}{|c|c|c|c|}
\hline \multirow{5}{*}{$\begin{array}{l}\text { ITEM } 6 \text { : Valid } \\
\text { reasons for } \\
\text { refusing job } \\
\text { offers }\end{array}$} & 1 & $\begin{array}{l}\text { Countries with a relatively large amount of } \\
\text { valid reasons for refusal }\end{array}$ & $\begin{array}{l}\text { Countries with five or more valid types of } \\
\text { reason for refusing jobs* }\end{array}$ \\
\hline & 2 & & \\
\hline & 3 & $\begin{array}{l}\text { Countries with average amount of } \\
\text { restrictions }\end{array}$ & $\begin{array}{l}\text { Countries with three or four valid types of } \\
\text { reason for refusing jobs* }\end{array}$ \\
\hline & 4 & & \\
\hline & 5 & $\begin{array}{l}\text { Countries with relatively few valid reasons for } \\
\text { refusal }\end{array}$ & $\begin{array}{l}\text { Countries with two or less valid types of reason } \\
\text { for refusing jobs* }\end{array}$ \\
\hline \multirow{5}{*}{$\begin{array}{l}\text { ITEM 7: } \\
\text { Proof of job } \\
\text { search }\end{array}$} & 1 & No systematic check of job-search activity & No check of job-search activity \\
\hline & 2 & & $\begin{array}{l}\text { Job-search activity can be checked upon } \\
\text { request }\end{array}$ \\
\hline & 3 & $\begin{array}{l}\text { The unemployed must regularly prove job- } \\
\text { search activity }\end{array}$ & $\begin{array}{l}\text { The unemployed must prove job-search } \\
\text { activity only when referred to a vacancy by the } \\
\text { PES }\end{array}$ \\
\hline & 4 & & $\begin{array}{l}\text { The unemployed must regularly prove job- } \\
\text { search activity }\end{array}$ \\
\hline & 5 & $\begin{array}{l}\text { The unemployed must often i.e. every week } \\
\text { or every second week prove job-search } \\
\text { activity }\end{array}$ & $\begin{array}{l}\text { The unemployed must often i.e. every week or } \\
\text { every second week prove job-search activity }\end{array}$ \\
\hline \multirow{5}{*}{$\begin{array}{l}\text { ITEM 8: } \\
\text { Sanctions for } \\
\text { refusing job } \\
\text { offers or } \\
\text { ALMP } \\
\text { participation }\end{array}$} & 1 & $0-4$ weeks & 0-4 weeks (including benefit reductions) \\
\hline & 2 & $5-9$ weeks & $5-9$ weeks \\
\hline & 3 & $10-14$ weeks & $10-14$ weeks \\
\hline & 4 & More than 14 weeks & More than 14 weeks \\
\hline & 5 & Suspension of unemployment benefits & Suspension of unemployment benefits \\
\hline \multirow{5}{*}{$\begin{array}{l}\text { ITEM 9: } \\
\text { Sanctions for } \\
\text { repeated } \\
\text { refusal of job } \\
\text { offers or } \\
\text { ALMP } \\
\text { participation }\end{array}$} & 1 & $\begin{array}{l}\text { No further sanction in case of repeated } \\
\text { rejections }\end{array}$ & 0-4 weeks (including benefit reductions) \\
\hline & 2 & $\begin{array}{l}\text { Sanctions are more rigorous after the third } \\
\text { rejection }\end{array}$ & 5-9 weeks \\
\hline & 3 & $\begin{array}{l}\text { Sanctions are more rigorous after the second } \\
\text { rejection and could lose entitlement to } \\
\text { benefits }\end{array}$ & $10-14$ weeks \\
\hline & 4 & $\begin{array}{l}\text { Suspension of unemployment benefits after } \\
\text { the second rejection }\end{array}$ & More than 14 weeks \\
\hline & 5 & $\begin{array}{l}\text { Benefit has already been suspended after } \\
\text { the first rejection }\end{array}$ & Suspension of unemployment benefits \\
\hline
\end{tabular}

* Valid types of reasons are classified into the following groups: family or personal reasons (e.g. caring responsibilities, spouse's work, lack of child care, etc.); own health or disability; the wage offered is lower than unemployment benefit or usual wage for that occupation; other working arrangements of the job (e.g. part-time, temporary contract, anti-social working hours, etc.); moral or religious reasons; or if the job is to replace workers on strike or lockout. It is assumed that all countries require suitable jobs to have wages and working conditions consistent with legal requirements or collective agreements, that certain types of work (e.g. prostitution) are not considered suitable work and that the unemployed should not be forced to join or leave a union or other organisation in order to take up suitable work, so these types of reasons are not counted in the total. 


\section{ANNEX B: DETAILED DESCRIPTION OF ELIBILITY CRITERIA AND SANCTIONS}

\section{Table B1. Employment and contribution requirements}

\begin{tabular}{|c|c|c|}
\hline Country & Description & $\begin{array}{l}\text { Score } \\
2011\end{array}$ \\
\hline Australia & None & 1 \\
\hline Austria & $\begin{array}{l}\text { Workers must have worked at least one out of the last two years and contributed one year. } \\
\text { Only } 28 \text { weeks suffice in case of repeated spells of unemployment. }\end{array}$ & 3 \\
\hline Belgium & $\begin{array}{l}\text { The employment condition increases with age. A worker aged } 36-49 \text { years must have } \\
\text { worked } 468 \text { days during } 27 \text { months. }\end{array}$ & 4 \\
\hline Bulgaria & $\begin{array}{l}\text { Workers for whom insurance instalments have been paid or are due in fund } \\
\text { "Unemployment" of the State Social Security at least } 9 \text { months during the last } 15 \text { months } \\
\text { before the termination of the insurance. }\end{array}$ & 2 \\
\hline Canada & $\begin{array}{l}\text { Entrance requirements vary with the local monthly unemployment rate. A minimum of } 420 \\
\text { hours of work in the preceding } 52 \text {-week period (qualifying period) is required in areas of } \\
\text { high unemployment (over } 13 \text { per cent) and } 700 \text { hours in areas of low unemployment ( } 6 \text { per } \\
\text { cent or lower). }\end{array}$ & 2 \\
\hline Cyprus & $\begin{array}{l}\text { Employment: The insured person has been insured under the Social Insurance Scheme for } \\
\text { at least } 26 \text { weeks before he/she became unemployed and has paid, up to the date of } \\
\text { unemployment, contributions on insurable earnings not lower than } 26 \text { times the weekly } \\
\text { amount of the basic insurable earnings. Contribution: The insured person has paid or been } \\
\text { credited with contributions in the previous contribution year on insurable earnings not lower } \\
\text { than } 20 \text { times the weekly amount of the basic insurable earnings. }\end{array}$ & 2 \\
\hline $\begin{array}{l}\text { Czech } \\
\text { Republic }\end{array}$ & $\begin{array}{l}\text { Contribution of at least } 12 \text { months during the three years prior to registration as } \\
\text { unemployed. }\end{array}$ & 3 \\
\hline Denmark & $\begin{array}{l}\text { After } 52 \text { weeks of full-time work within the last three years, the employee is entitled to } \\
\text { benefit immediately on becoming unemployed. }\end{array}$ & 3 \\
\hline Estonia & $\begin{array}{l}\text { Contributions must be paid for at least } 12 \text { months within the } 36 \text { months prior to loss of } \\
\text { employment. }\end{array}$ & 3 \\
\hline Finland & $\begin{array}{l}\text { Employment: } 34 \text { weeks of work (minimum of } 18 \text { hours per week) in the last } 28 \text { months; } \\
\text { Contribution: } 10 \text { months of voluntary contribution to an insurance fund preceding the claim. }\end{array}$ & 2 \\
\hline France & $\begin{array}{l}\text { Contributions for at least } 122 \text { days ( } 4 \text { months) or } 610 \text { hours in the last } 28 \text { months (or in the } \\
\text { last } 36 \text { months for those aged } 50+\text { years). }\end{array}$ & 2 \\
\hline Germany & Normally 12 months; 6 months for predominantly briefly-employed persons. & 3 \\
\hline Greece & $\begin{array}{l}\text { Either (i) } 125 \text { days of employment in the last } 14 \text { months prior to applying for the benefit; or } \\
\text { (ii) } 200 \text { days of employment in the last } 2 \text { years prior to applying for the benefit. }\end{array}$ & 2 \\
\hline Hungary & $\begin{array}{l}\text { Payment of contributions for at least } 365 \text { days during the previous } 4 \text { years. If he/she spent } \\
\text { at least } 200 \text { days in employment over the four years prior to becoming a jobseeker, the } \\
\text { jobseeker shall be granted jobseeker aid for } 90 \text { days. }\end{array}$ & 3 \\
\hline Ireland & 104 weeks & 4 \\
\hline Israel & $\begin{array}{l}\text { Unemployment benefit qualifying period is } 360 \text { days for which insurance contributions were } \\
\text { paid out of } 540 \text { days prior to determining date. For daily employee: } 300 \text { days of the above } \\
\text { out of } 540 \text { days. }\end{array}$ & 3 \\
\hline Italy & $\begin{array}{l}\text { Ordinary benefits are paid to workers who have two years of insurance and } 52 \text { weekly } \\
\text { contributions during the last two years. }\end{array}$ & 4 \\
\hline Japan & $\begin{array}{l}\text { Contribution: The applicant must have been insured for a period of more than } 12 \text { months, } \\
\text { with more than } 11 \text { days per month, over } 2 \text { years before unemployment. Applicants who are } \\
\text { made redundant or are unemployed as a result of bankruptcy or dismissal must have been } \\
\text { insured for a period of more than } 6 \text { months over } 1 \text { year before unemployment. Employment: } \\
\text { Normal cases: more than twelve months (worked more than } 11 \text { days) of UI membership in } \\
2 \text { years. Dismissal, bankruptcy, non-renewal of a fixed-term contract: six months (worked } \\
\text { more than } 11 \text { days) of UI membership in } 1 \text { year. }\end{array}$ & 2 \\
\hline Korea & Must be insured for 180 days during 18 months before leaving job. & 2 \\
\hline
\end{tabular}




\begin{tabular}{|c|c|c|}
\hline Country & Description & $\begin{array}{l}\text { Score } \\
2011\end{array}$ \\
\hline Lithuania & $\begin{array}{l}\text { Social insurance contributions must have been made for at least } 18 \text { months in the last } 36 \\
\text { months. }\end{array}$ & 4 \\
\hline Luxembourg & $\begin{array}{l}\text { The claimant must have been employed for } 26 \text { weeks in the } 12 \text { months preceding } \\
\text { unemployment at least for } 16 \text { hours a week. }\end{array}$ & 2 \\
\hline Malta & $\begin{array}{l}\text { A person must have at least } 50 \text { weekly social security contributions of which } 20 \text { should } \\
\text { have been contributed in the benefit year }\end{array}$ & 3 \\
\hline Netherlands & Must have worked 26 weeks in the last 36 weeks immediately preceding unemployment. & 2 \\
\hline New Zealand & None & 1 \\
\hline Norway & $\begin{array}{l}\text { A precondition for entitlement to daily cash benefits during unemployment is that the person } \\
\text { concerned must have had an income from work of at least } 1.5 \text { times the basic amount } \\
\text { (NOK } 113462 \text { ) the preceding calendar year or an income from work which at least equals } 3 \\
\text { times the basic amount as an average during the three preceding calendar years } \\
\text { (NOK226 923). }\end{array}$ & 2 \\
\hline Poland & $\begin{array}{l}\text { The person during the period of } 18 \text { months preceding the day of registration should be } \\
\text { employed for a period of at least } 365 \text { days. }\end{array}$ & 3 \\
\hline Portugal & $\begin{array}{l}\text { Employment condition for UI eligibility is } 450 \text { days of employment record in the last } 24 \\
\text { months before unemployment. Eligibility is dependent on the involuntary of the } \\
\text { unemployment status. }\end{array}$ & 4 \\
\hline Romania & Minimum period of contribution of 12 months in the last 24 months & 3 \\
\hline $\begin{array}{l}\text { Slovak } \\
\text { Republic }\end{array}$ & $\begin{array}{l}\text { Insuree is entitled to unemployment benefit, if he had unemployment insurance for at least } \\
\text { three years within the past four years before being included to registry of unemployed } \\
\text { citizens looking for employment or for at least two years within the past four years before } \\
\text { being included to registry of unemployed citizens looking for employment in case of } \\
\text { seasonal workers (i.e. workers with term contract). }\end{array}$ & 5 \\
\hline Slovenia & $\begin{array}{l}\text { Unemployment insurance rights may be obtained by an unemployed person who was } \\
\text { insured for at least nine months in the last } 24 \text { months before the unemployment occurred } \\
\text { (prior to } 2011 \text {, the minimum contribution requirement was } 12 \text { months in the last } 18 \text { months). }\end{array}$ & 2 \\
\hline Spain & $\begin{array}{l}\text { A claimant must have contributed for a minimum of } 360 \text { days in the } 6 \text { years preceding the } \\
\text { legal status of unemployment }\end{array}$ & 3 \\
\hline Sweden & $\begin{array}{l}\text { Employment: A recipient must have worked at least } 6 \text { months (with at least } 80 \text { hours per } \\
\text { month) or } 480 \text { hours during a continuous period of } 6 \text { months (with at least } 50 \text { hours each } \\
\text { month). Contribution: An employee or a self-employed person must have been a member } \\
\text { of an Unemployment Insurance Society for the last } 12 \text { months. }\end{array}$ & 3 \\
\hline Switzerland & $\begin{array}{l}12 \text { months contributions in the previous } 2 \text { years. Exceptions to this rule are provided in } \\
\text { certain circumstances, such as if the person was not working for at least } 12 \text { months due to } \\
\text { undertaking training, illness, accident, maternity leave, was re-entering the workforce after } \\
\text { divorce or withdrawal of a disability pension or after working abroad. }\end{array}$ & 3 \\
\hline Turkey & $\begin{array}{l}\text { Insured unemployed should pay at least } 600 \text { days of contributions in the } 3 \text { years before } \\
\text { unemployment, including the last } 120 \text { days of employment. }\end{array}$ & 4 \\
\hline $\begin{array}{l}\text { United } \\
\text { Kingdom }\end{array}$ & $\begin{array}{l}\text { JSA (contribution-based) is paid to unemployed people who have paid sufficient National } \\
\text { Insurance contributions in the last two full tax years before they make their claim. Sufficient } \\
\text { means: contributions paid in one of the } 2 \text { tax years on which the claim is based amounting } \\
\text { to at least (i) for claims dated on or after } 1 \text { November } 2010,26 \text { times the minimum weekly } \\
\text { contribution for that year [earnings above the minimum are disregarded, effectively } \\
\text { meaning that the person will have to have been employed for at least } 26 \text { weeks - though } \\
\text { not necessarily continuously]. Prior to this the requirement was } 25 \text { times the minimum } \\
\text { weekly contribution for that year; and (ii) contributions paid or credited in both the } \\
\text { appropriate tax years amounting to a total of at least } 50 \text { times the minimum contribution for } \\
\text { that year. }\end{array}$ & 2 \\
\hline United States & $\begin{array}{l}\text { Entitlement conditions vary across states. Typically, the unemployed person must work for } \\
\text { a minimum number of weeks or earn a minimum amount of earnings in the base period, } \\
\text { which is the first four quarters of the five quarters immediately preceding the claim for } \\
\text { unemployment benefits. For a full-time worker earning the average wage, the unweighted } \\
\text { average number of weeks required to qualify for benefits in the seven largest states. } \\
\text { (assuming that they worked until the last day of a quarter and made a claim on the first day } \\
\text { of the next quarter) is } 27 \text { weeks. }\end{array}$ & 2 \\
\hline
\end{tabular}


Table B2. Sanctions in case of resignation from previous job

\begin{tabular}{|c|c|c|}
\hline Country & Description & $\begin{array}{l}\text { Score } \\
2011\end{array}$ \\
\hline Australia & $\begin{array}{l}\text { If the person became unemployed due to a voluntary act or became unemployed because } \\
\text { of misconduct, an unemployment non-payment period applies. This means that a payment } \\
\text { is not payable to the person for } 8 \text { weeks (or } 12 \text { weeks for a person who leaves a job after } \\
\text { receiving relocation assistance). }\end{array}$ & 2 \\
\hline Austria & $\begin{array}{l}\text { If a person loses the job due to his/her own fault or terminates work voluntarily, no } \\
\text { entitlement to benefits under the unemployment insurance scheme will apply for the first } \\
\text { four weeks. In this case, the duration of benefits' payment is not shortened but postponed. } \\
\text { If certain circumstances apply, the sanction can be partially or fully revoked. }\end{array}$ & 1 \\
\hline Belgium & $\begin{array}{l}\text { A worker who leaves a job without proper reason can be temporarily excluded from } \\
\text { receiving benefits for a period of } 4-52 \text { weeks. In place of a sanction, the unemployed can } \\
\text { be issued with a warning in extenuating circumstances if in the two preceding years, no } \\
\text { similar event giving rise to an exclusion occurred. The sanction can be a total loss of rights } \\
\text { to benefits if it can be shown that the worker left the job with the deliberate intention of } \\
\text { receiving unemployment benefits. Typical sanction } 5-9 \text { weeks. }\end{array}$ & 2 \\
\hline Bulgaria & $\begin{array}{l}\text { Unemployed persons whose employment has been terminated on their own initiative or } \\
\text { because of their guilty behavior shall be granted the minimum amount of the unemployment } \\
\text { benefit in cash for a period of } 4 \text { months. }\end{array}$ & 1 \\
\hline Canada & $\begin{array}{l}\text { A disqualification from El benefits is imposed when a claimant fails to prove that leaving } \\
\text { their employment was the only reasonable alternative available to them under the } \\
\text { circumstances. A disqualification for voluntarily leaving employment without just cause is } \\
\text { indefinite and applies to all weeks of the benefit period for which regular benefits are } \\
\text { requested. }\end{array}$ & 5 \\
\hline Cyprus & $\begin{array}{l}\text { In case the job loss is "voluntary" or due to the employee's fault then the payment of the } \\
\text { unemployment benefit may be postponed for up to six weeks. }\end{array}$ & 2 \\
\hline $\begin{array}{l}\text { Czech } \\
\text { Republic }\end{array}$ & $\begin{array}{l}\text { In case the jobseeker quits him/herself a job without serious reason or agreed on job } \\
\text { termination with his/her employer preceding his/her Labour Office registration, the } \\
\text { unemployment benefit amounts to } 45 \% \text { of average monthly net wage for the duration of the } \\
\text { benefit period (compared with } 65 \% \text { for the first two months, } 50 \% \text { in the following } 2 \text { months } \\
\text { and } 45 \% \text { in the remaining months. Total support period is } 5 \text { months for jobseekers under } 50 \\
\text { years, } 8 \text { months for those aged } 50-55 \text { years and } 11 \text { months for those aged over } 55 \text { years). } \\
\text { The jobseeker is not entitled to unemployment benefits if the employer terminated his/her } \\
\text { job due to a serious breach of duty or if the jobseeker him/herself repeatedly terminated a } \\
\text { suitable job in the past } 6 \text { months. }\end{array}$ & 1 \\
\hline Denmark & $\begin{array}{l}\text { The person is quarantined for } 3 \text { weeks where he would otherwise have been entitled to } \\
\text { unemployment benefits. }\end{array}$ & 1 \\
\hline Estonia & $\begin{array}{l}\text { There is no right to receive unemployment insurance benefit if the unemployment is } \\
\text { voluntary i.e. the employment contract has been terminated by the agreement between an } \\
\text { employee and an employer or at the initiative of the employee. If the unemployed person } \\
\text { has quite a job voluntarily and is now registered as unemployed, actively looking for work } \\
\text { and has worked or engaged in other activities for at least } 180 \text { days prior to the registration } \\
\text { as unemployed, he/she will be entitled to unemployment allowance. }\end{array}$ & 5 \\
\hline Finland & $\begin{array}{l}\text { If an unemployed person quits a job without good cause, he/she loses entitlement to } \\
\text { unemployment benefit usually for } 90 \text { days after the termination of employment. If the } \\
\text { remaining duration of employment would have been } 5 \text { days at a maximum, unemployment } \\
\text { benefit will be lost for } 30 \text { days. }\end{array}$ & 3 \\
\hline France & $\begin{array}{l}\text { People quitting a job without good reason will not obtain unemployment benefit before four } \\
\text { months after the beginning of unemployment. Good reasons can include to follow a spouse } \\
\text { who changes residence, for non-payment of salary, etc. }\end{array}$ & 4 \\
\hline Germany & $\begin{array}{l}\text { If a person has terminated employment thus causing unemployment deliberately or through } \\
\text { negligence without good reasons, benefits will as a general rule be suspended for twelve } \\
\text { weeks. In addition, the period of entitlement to unemployment benefit will be cut by the } \\
\text { suspension time, at least by a quarter of the period of entitlement. }\end{array}$ & 3 \\
\hline Greece & In case of resignation, the unemployed person is not entitled to unemployment benefit. & 5 \\
\hline Hungary & 90 calendar day waiting period exists after registration with Labour Centre. & 3 \\
\hline Ireland & $\begin{array}{l}\text { People leaving employment voluntarily may be disqualified for a period of up to nine weeks } \\
\text { from the date of leaving last employment. }\end{array}$ & 2 \\
\hline Israel & $\begin{array}{l}\text { An intentional and unjustified termination of work rules out payment of unemployment } \\
\text { benefit for } 90 \text { days from the termination of work. }\end{array}$ & 3 \\
\hline
\end{tabular}




\begin{tabular}{|c|c|c|}
\hline Country & Description & $\begin{array}{l}\text { Score } \\
2011\end{array}$ \\
\hline Italy & $\begin{array}{l}\text { People quitting a job will not obtain unemployment benefits unless they show that they were } \\
\text { not paid, or that they suffered sexual harassment, or their tasks were changed. }\end{array}$ & 5 \\
\hline Japan & $\begin{array}{l}\text { A person quitting a job will not obtain unemployment benefit before } 3 \text { months after finishing } \\
\text { the waiting period (a total of seven days counting from the day of first job application). }\end{array}$ & 3 \\
\hline Korea & $\begin{array}{l}\text { Those who are discharged for their own material misconduct such as illegal appropriation of } \\
\text { those who have voluntarily changed jobs for personal reasons do not qualify for } \\
\text { unemployment benefits. }\end{array}$ & 5 \\
\hline Lithuania & $\begin{array}{l}\text { An unemployed, who is dismissed for misconduct will receive unemployment benefits after } \\
\text { three months of registration at the Labour exchange instead of eight days as usual. There } \\
\text { are no sanctions for unemployed who resign voluntarily from their previous job. }\end{array}$ & 1 \\
\hline Luxembourg & $\begin{array}{l}\text { Unemployment benefit is only paid in cases of involuntary unemployment. No benefit will be } \\
\text { paid if the unemployed person left their previous job without exceptional reasons. }\end{array}$ & 5 \\
\hline Malta & $\begin{array}{l}\text { In cases where unemployed persons quit their job without good cause (supported by } \\
\text { documentation), he/she will be registered under Part } 2 \text { of the unemployment register for six } \\
\text { months, which means that a jobseeker will lose entitlement to benefits as well as priority on } \\
\text { the unemployment register. }\end{array}$ & 4 \\
\hline Netherlands & $\begin{array}{l}\text { If the employee is culpable unemployed and if the employment relationship was finished } \\
\text { without any objection from the employer, then the employee is not entitled to } \\
\text { unemployment benefits. }\end{array}$ & 5 \\
\hline New Zealand & $\begin{array}{l}\text { A person who quits a job voluntarily is not entitled to a benefit for } 13 \text { weeks from the date } \\
\text { his or her employment ceased. A person subject to a } 13 \text { week non-entitlement period can } \\
\text { complete certain activities for a continuous period of } 6 \text { weeks (or until then end of the } 13 \\
\text { week non-entitlement period, whichever is the earlier) in order to get a provisional benefit. } \\
\text { Approved activities include full-time employment and participation in an employment skills } \\
\text { programme or employment-related training. }\end{array}$ & 3 \\
\hline Norway & $\begin{array}{l}\text { If a person quits a job without good cause, the jobseeker will be subject to a waiting period } \\
\text { of minimum } 8 \text { weeks before he/she will receive benefits. }\end{array}$ & 2 \\
\hline Poland & $\begin{array}{l}\text { If within a period of } 6 \text { months preceding registration, the unemployed terminated the } \\
\text { employment contract with notice or with the agreement of the employer, the unemployed } \\
\text { cannot obtain benefits for } 90 \text { days. If the employment contract was terminated by the } \\
\text { employee without notice, unemployment benefit cannot be obtained for } 180 \text { days. }\end{array}$ & 4 \\
\hline Portugal & $\begin{array}{l}\text { When the employment contract ends by the employee's initiative and that end is not } \\
\text { considered justified or with good cause, then the employee can be registered as seeking } \\
\text { employment but cannot be a beneficiary of unemployment benefits. }\end{array}$ & 5 \\
\hline Romania & $\begin{array}{l}\text { If employment is terminated for reasons imputable to the unemployed person, they are not } \\
\text { eligible to receive unemployment benefit. }\end{array}$ & 5 \\
\hline $\begin{array}{l}\text { Slovak } \\
\text { Republic }\end{array}$ & $\begin{array}{l}\text { When assessing entitlement to unemployment benefit, the reason why previous } \\
\text { employment ended is not examined. }\end{array}$ & 1 \\
\hline Slovenia & A person who is voluntarily unemployed will not be eligible for unemployment benefit. & 5 \\
\hline Spain & $\begin{array}{l}\text { To obtain unemployment benefits, workers must, among other requirements, have lost their } \\
\text { jobs for involuntary reasons and will not be considered if their employment was voluntarily } \\
\text { terminated. }\end{array}$ & 5 \\
\hline Sweden & $\begin{array}{l}\text { An applicant will be suspended from benefit for } 45 \text { benefit days ( } 9 \text { weeks) if he or she } \\
\text { leaves his or her work without valid cause or for } 60 \text { benefit days ( } 12 \text { weeks) if he or she is } \\
\text { suspended from work owing to improper conduct. }\end{array}$ & 3 \\
\hline Switzerland & $\begin{array}{l}\text { If the unemployed left a suitable job without being sure of having a new job, they are } \\
\text { subject to a benefit suspension of } 31-60 \text { benefit days (6-12 weeks). }\end{array}$ & 2.5 \\
\hline Turkey & The unemployed person will not be eligible for unemployment benefit. & 5 \\
\hline United & A variable sanction of $1-26$ weeks depending on the circumstances of the case will apply & 3 \\
\hline Kingdom & $\begin{array}{l}\text { when a jobseeker contributes to his own unemployment by leaving a job voluntarily without } \\
\text { just cause. "Just cause" involves balancing the interest of the jobseeker with those of the } \\
\text { wider community. }\end{array}$ & \\
\hline United States & $\begin{array}{l}\text { The reason for the separation from employment is examined. In general, individuals will be } \\
\text { disqualified from receiving UI benefits if they voluntarily quit their jobs without good cause } \\
\text { attributable to the work. The states differ, however, in their approaches to defining what } \\
\text { constitutes good cause. Individuals can purge their disqualifications for voluntarily quitting } \\
\text { their employment, typically by returning to work or serving a period of disqualification. The } \\
\text { specific sanctions vary from state to state. In the seven largest states, disqualification lasts } \\
\text { until the unemployed finds a new job. }\end{array}$ & 5 \\
\hline
\end{tabular}


Table B3. Availability for work during participation in ALMPs

\begin{tabular}{|c|c|c|}
\hline Country & Description & $\begin{array}{l}\text { Score } \\
2011\end{array}$ \\
\hline Australia & $\begin{array}{l}\text { Jobseekers must meet the general requirements under the activity test - i.e. to be actively } \\
\text { seeking and prepared to accept suitable paid work - and must participate in additional } \\
\text { activities when required to do so. These activities may include actively looking for work } \\
\text { and/or undertaking activities which are designed to help them become ready for work in the } \\
\text { future. The activity test recognises that the primary focus for jobseekers who are not early } \\
\text { school leavers should be finding work. Principal carer jobseekers who are meeting their } \\
\text { requirements through paid work, study or a combination of the two for at least } 30 \text { hours per } \\
\text { fortnight are not required to remain connected to their employment services provider or } \\
\text { accept any offers of suitable paid work. }\end{array}$ & 5 \\
\hline Austria & Continuing availability for work is generally required while participating in ALMPs. & 4 \\
\hline Belgium & $\begin{array}{l}\text { Unemployed persons taking part in training organised by the regional employment service } \\
\text { or engaged full-time in a job creation programme do not have to be available or actively } \\
\text { looking for work. Those taking part in full-time training programmes that are not organised } \\
\text { by the regional employment service can request to have their availability and job-search } \\
\text { requirements lifted. Unemployed people participating in training programmes lasting less } \\
\text { than } 4 \text { weeks or in part-time training or job creation programmes are still required to be } \\
\text { available and looking for work. }\end{array}$ & 2 \\
\hline Bulgaria & $\begin{array}{l}\text { During participation of unemployed people in subsidised employment programmes, their } \\
\text { registration in the employment agency is suspended and they are not provided with any } \\
\text { information about vacancies for the duration of their participation in the programme. }\end{array}$ & 1 \\
\hline Canada & $\begin{array}{l}\text { Employment Insurance claimants participating in an approved course or program are not } \\
\text { required to prove their continued availability. }\end{array}$ & 1 \\
\hline Cyprus & $\begin{array}{l}\text { Continuing availability for work is required during participation in training programmes } \\
\text { proposed by the PES and organised by the Human Resource Development Authority or the } \\
\text { Cyprus Productivity Centre. During occupational training, approved by the Minister of } \\
\text { Labour and Social Insurance Services, the unemployment benefit may be given to the } \\
\text { Authority responsible for implementation of the programme instead and the unemployed } \\
\text { person will receive a payment from the Authority. Usually though, this is not applied. }\end{array}$ & 3 \\
\hline $\begin{array}{l}\text { Czech } \\
\text { Republic }\end{array}$ & $\begin{array}{l}\text { Generally, job mediation is not provided while a person is involved in vocational training, } \\
\text { community service and socially beneficial jobs. In case of these jobs, persons are } \\
\text { temporarily removed from the jobseeker's list because they have a contract with the } \\
\text { employer who has to submit in scheduled time bills for repayment, especially of wage } \\
\text { costs. If the jobseeker finds him/herself a job during vocational training, an agreement with } \\
\text { the new employer has to be made. He can either complete the course or terminate it ahead } \\
\text { of schedule for employment reasons without any financial sanctions. }\end{array}$ & 4 \\
\hline Denmark & $\begin{array}{l}\text { In general, the unemployed person must remain available for work during ALMP } \\
\text { participation. If participation in/completion of a specific employability enhancement measure } \\
\text { will most likely result in ordinary work the local job centre can decide that the unemployed } \\
\text { person has to be available for that specific measure only. Participants in ALMPs need to } \\
\text { continue active job search and accept job referrals. }\end{array}$ & 5 \\
\hline Estonia & $\begin{array}{l}\text { The unemployed must remain available and actively searching for work during participation } \\
\text { in ALMPs. }\end{array}$ & 5 \\
\hline Finland & $\begin{array}{l}\text { Legislation specifies that if an unemployed person is engaged in labour market training or } \\
\text { pursuing self-motivated studies, eligibility for unemployment benefit does not require } \\
\text { accepting any normal job. However, while using other services provided by the TE Office, } \\
\text { the jobseeker must be prepared to accept normal jobs in order to be eligible for } \\
\text { unemployment benefit. Principle of interpretation ("good cause" in legislation is not } \\
\text { exhaustive): Should the job applicant refuse, the TE Office will assess whether continuing } \\
\text { with the service would be more helpful in finding employment later. If this is so, refusing } \\
\text { work will not result in loss of unemployment benefit. }\end{array}$ & 3 \\
\hline France & $\begin{array}{l}\text { The unemployed must accept jobs offers during participation in ALMPs but are not obliged } \\
\text { to provide evidence of job search. }\end{array}$ & 4 \\
\hline Germany & $\begin{array}{l}\text { The employment agency may place a jobless person in an acceptable training measure or } \\
\text { job while this person participates in an integration programme. Unemployed persons are } \\
\text { required to continue making their own efforts when participating in ALMPs. }\end{array}$ & 5 \\
\hline
\end{tabular}




\begin{tabular}{|c|c|c|}
\hline Country & Description & $\begin{array}{l}\text { Score } \\
2011\end{array}$ \\
\hline Greece & $\begin{array}{l}\text { Continuous availability for regular work is required until the jobseeker is proposed to } \\
\text { participate in an ALMP. The unemployment status of every person registered with the } \\
\text { OAED unemployment registries is interrupted as soon as they start attending a training } \\
\text { programme. The same applies if the unemployed person participates in programmes for the } \\
\text { creation of new jobs. }\end{array}$ & 1 \\
\hline Hungary & $\begin{array}{l}\text { During participation in a labour market programme the unemployed person's availability } \\
\text { pauses. }\end{array}$ & 1 \\
\hline Ireland & $\begin{array}{l}\text { Unemployed people who are participating in FÁS full time training programmes and } \\
\text { receiving a training allowance are removed from the Live Register and therefore are not } \\
\text { considered to be actively seeking employment. FÁS also offer part-time (evening) and } \\
\text { online training programmes, unemployed participants on these courses do not receive a } \\
\text { training allowance from FÁS and retain their social welfare payments while participating on } \\
\text { the course, therefore participants of these courses would be subject to social welfare rules } \\
\text { and would be actively seeking employment. Individuals on ALMPs that are part-time, } \\
\text { including programmes under the Labour Market Activation Fund and in receipt of social } \\
\text { welfare allowances while participating on these courses are expected to be actively seeking } \\
\text { employment. }\end{array}$ & 2 \\
\hline Israel & The unemployed are not required to remain available for work during ALMP participation. & 1 \\
\hline Italy & $\begin{array}{l}\text { Participation in ALMPs does not prevent workers from accepting job offers or from applying } \\
\text { for jobs, but currently there is no job search obligation for the unemployed. }\end{array}$ & 4 \\
\hline Japan & $\begin{array}{l}\text { When people participate in public vocational training following the instruction of the head of } \\
\text { PESO, they are normally required to be willing to work. Employment Insurance benefit } \\
\text { recipients who participate in public vocational training are not required to engage in job } \\
\text { search or attend interviews with the PES, but it is possible for them to carry out job seeking } \\
\text { activities voluntarily. When Employment Insurance benefit recipients receive career } \\
\text { counselling and other vocational counselling services, they need to have willingness to } \\
\text { work. Thus they are always available for work while receiving those services. }\end{array}$ & 4 \\
\hline Korea & $\begin{array}{l}\text { The unemployed are deemed to have searched for work during participation in ALMPs such } \\
\text { as skills development. Additional activities for re-employment are unnecessary. Therefore, } \\
\text { there are no demands on job availability or job seeking during participation in ALMPs. }\end{array}$ & 1 \\
\hline Lithuania & $\begin{array}{l}\text { There is no requirement to be available and actively searching for work while } \\
\text { unemployment benefit recipients take part in ALMPs such as training, work experience and } \\
\text { subsidised job placements. }\end{array}$ & 1 \\
\hline Luxembourg & $\begin{array}{l}\text { In general, jobseekers must remain available for work while participating in ALMPs. Some } \\
\text { exceptions exist for internships for young jobseekers or for professional training that is } \\
\text { organised with a specific business where the jobseeker will be hired by the business at the } \\
\text { end of the training. }\end{array}$ & 3 \\
\hline Malta & $\begin{array}{l}\text { A job offer or an interview always takes precedence over any ALMP offered by the PES. } \\
\text { These must be backed up by relevant documentation to justify respective claims. }\end{array}$ & 5 \\
\hline Netherlands & $\begin{array}{l}\text { During participation in ALMPs the unemployed has to accept a job offer and is obliged to } \\
\text { search for work. Unemployed enjoying their holidays or being older than } 64 \text { years are } \\
\text { exempted from these obligations. Also exempted are unemployed that follow a 'necessary' } \\
\text { education and who will finish this education within } 2 \text { months. }\end{array}$ & 5 \\
\hline New Zealand & $\begin{array}{l}\text { Regardless of which programmes a person is referred to they still have to be seeking, } \\
\text { available for and willing to undertake work. }\end{array}$ & 5 \\
\hline Norway & $\begin{array}{l}\text { Jobseekers are to be available for ordinary work during participation in ALMPs. However, } \\
\text { the PES will seldom instruct jobseekers to discontinue ALMP participation since completion } \\
\text { is considered to increase job possibilities. }\end{array}$ & 4 \\
\hline Poland & $\begin{array}{l}\text { The unemployed must accept suitable job offers during participation in ALMPs but are not } \\
\text { obliged to actively search for work. }\end{array}$ & 4 \\
\hline Portugal & $\begin{array}{l}\text { In principle, when the unemployed is participating in ALMPs, including vocational training, } \\
\text { they are temporarily considered as no longer searching for work or available for work for } \\
\text { the duration of the period of participation. }\end{array}$ & 1 \\
\hline Romania & $\begin{array}{l}\text { Unemployed persons who receive free training services must be available to start work and } \\
\text { actively looking for work. If they are offered a job they can either withdraw from the training } \\
\text { without incurring a cost. }\end{array}$ & 5 \\
\hline $\begin{array}{l}\text { Slovak } \\
\text { Republic }\end{array}$ & $\begin{array}{l}\text { An unemployed person is available for work during participation in ALMPs. However, if they } \\
\text { are participating in education and preparation for the labour market for more than two } \\
\text { months, they will only be required to report to the Labour Office to prove job search during } \\
\text { the last two months prior to completion. }\end{array}$ & 4 \\
\hline
\end{tabular}




\begin{tabular}{ll}
\hline Country & \multicolumn{1}{c}{ Description } \\
\hline Slovenia & $\begin{array}{l}\text { Generally, unemployed persons must be available and searching for work while } \\
\text { participating in ALMPs. In some cases, the unemployed person and a counsellor might } \\
\text { agree in the employment plan to exempt the unemployed person from job search. In this } \\
\text { case, while they are participating in the ALMP, they are removed from the register of } \\
\text { unemployed persons and registered as an ALMP participant. }\end{array}$ \\
Unemployed persons must renew their registration as a jobseeker with the PES every 4 \\
Spain & $\begin{array}{l}\text { The unemployed person is required to be available and actively searching for work during } \\
\text { participation in ALMPs. }\end{array}$ \\
Sweden & $\begin{array}{l}\text { All unemployment benefit recipients, including those who participate in labour market } \\
\text { measures, are required to search for work unless they are specifically exempted. }\end{array}$ \\
\hline Exemptions may be made in some circumstances, including for pregnant women or new \\
mothers on maternity leave, in the six months preceding retirement age, if the unemployed \\
has a suitable job starting next month, if they are developing a sustainable self-employment \\
opportunity or if they are undertaking a motivation course to help them chose a training \\
programme.
\end{tabular}

Table B4. Demands on occupational mobility

\begin{tabular}{|c|c|c|}
\hline Country & Description & $\begin{array}{l}\text { Score } \\
2011\end{array}$ \\
\hline Australia & $\begin{array}{l}\text { Jobseekers should not restrict their job search to their usual occupation or work that they } \\
\text { would prefer to do. They should seek and be prepared to accept any suitable employment. }\end{array}$ & 5 \\
\hline Austria & $\begin{array}{l}\text { In the first } 100 \text { days of drawing unemployment benefit, placement in employment not } \\
\text { corresponding to the previous activity is not regarded as reasonable if future employment in } \\
\text { the previous occupation is thereby made substantially more difficult. In the first } 120 \text { days of } \\
\text { drawing unemployment benefit, employment in another occupation is considered to be } \\
\text { reasonable only if the remuneration subject to compulsory social insurance is equal to at } \\
\text { least } 80 \% \text { of the remuneration corresponding to the last assessment basis for } \\
\text { unemployment benefit. In the remaining period of drawing unemployment benefit, } \\
\text { employment in a different occupation is considered reasonable only if the remuneration is } \\
\text { equal to at least } 75 \% \text { of previous remuneration. }\end{array}$ & 3 \\
\hline Belgium & $\begin{array}{l}\text { During the first six months of unemployment, the unemployed can limit their job search to a } \\
\text { job corresponding to the profession in which they studied, their normal profession or a } \\
\text { related profession. This exemption may not apply if there are few job opportunities in this } \\
\text { profession. After six months, the unemployed must accept and search for jobs in other } \\
\text { professions, taking into account their skills and training. Jobseekers aged over } 50 \text { are able } \\
\text { to limit their job search to their own profession indefinitely. }\end{array}$ & 2 \\
\hline Bulgaria & $\begin{array}{l}\text { Up to } 18 \text { months of unemployment, there are no sanctions for the unemployed if they are } \\
\text { not ready to make serious changes in their career and a job vacancy is only considered } \\
\text { suitable if it matches the education and training of the unemployed person. After } 18 \text { months } \\
\text { of unemployment, this is no longer a valid reason for refusing a job offer. }\end{array}$ & 2 \\
\hline
\end{tabular}




\begin{tabular}{|c|c|c|}
\hline Country & Description & $\begin{array}{l}\text { Score } \\
2011\end{array}$ \\
\hline Canada & $\begin{array}{l}\text { An El claimant is allowed to restrict their job search to their own skills set or training level, } \\
\text { however gradual reductions in an individual's demands are expected the longer the } \\
\text { duration of the period of unemployment. Where a claimants expectations appear restrictive } \\
\text { in nature, the acceptable practice is to allow a reasonable period of time (around } 3 \text { weeks, } \\
\text { but may vary depending on their employment history, skills, salary level, etc.) for them to } \\
\text { explore the labour market provided that opportunities exist within those limitations. After this } \\
\text { period, the inability to find work would be considered to be attributable to those limitations, } \\
\text { which will then be regarded as unduly restrictive. A claimant's availability for work would } \\
\text { also be reconsidered in cases where their demands cast doubt on their interest in seeking } \\
\text { employment and/or desire to find work as quickly as possible. }\end{array}$ & 4 \\
\hline Cyprus & $\begin{array}{l}\text { The unemployed person has the right to refuse any job that is not considered suitable. A } \\
\text { job will not be considered suitable if it is in the unemployed person's usual occupation but } \\
\text { with lower compensation or less favourable terms than expected, given the previous job, } \\
\text { the conditions of a collective agreement or based on what good employers consider as } \\
\text { expected. After a reasonable time period a suitable job can be considered as any job other } \\
\text { than the person's usual occupation if it meets expectations on compensation and work } \\
\text { terms/conditions. }\end{array}$ & 2 \\
\hline $\begin{array}{l}\text { Czech } \\
\text { Republic }\end{array}$ & $\begin{array}{l}\text { Suitable employment should correspond, as far as possible, to the unemployed person's } \\
\text { qualifications, abilities and length of previous employment. }\end{array}$ & 4 \\
\hline Denmark & $\begin{array}{l}\text { The unemployed person has to be available for (and take on) reasonable work. Reasonable } \\
\text { work is defined as any kind of work that the unemployed person can handle - e.g. after a } \\
\text { short training period. }\end{array}$ & 5 \\
\hline Estonia & $\begin{array}{l}\text { During the first } 20 \text { weeks after registration as unemployed, the definition of suitable job } \\
\text { takes into account the education, profession and earlier work experience of the } \\
\text { unemployed person and previous salary (jobseeker does not have the obligation to take a } \\
\text { job if the offered salary is less than } 60 \% \text { of the previous average gross income). Starting } \\
\text { from } 21 \text { weeks after registration, the person has to accept job offers that do not correspond } \\
\text { to their education, profession or earlier work experience. The salary should be higher than } \\
\text { the unemployment benefit. }\end{array}$ & 3 \\
\hline Finland & $\begin{array}{l}\text { An job applicant may refuse to accept work that does not correspond to his/her professional } \\
\text { skills during the first three months of unemployment. Professional skills refer to } \\
\text { competencies gained through work experience or training. If the TE Office is of the view } \\
\text { that work corresponding to the job applicant's professional skills cannot be offered during } \\
\text { the first three months of unemployment, the protection related to professional skills may be } \\
\text { lifted. }\end{array}$ & 3 \\
\hline France & $\begin{array}{l}\text { To determine the scope of the job search, the applicant's training, qualifications, knowledge } \\
\text { and skills acquired during his professional experience, his personal and family situation, } \\
\text { and the local labour market situation are taken into account. After three months of } \\
\text { unemployment, the jobseeker must gradually expand the scope of job search beyond a } \\
\text { single specialty and to encourage jobseekers to take up any jobs that their skills allow them } \\
\text { to practice. }\end{array}$ & 3 \\
\hline Germany & $\begin{array}{l}\text { In principle an unemployment benefit recipient may be expected to accept any job } \\
\text { corresponding to his working capacities to the extent that general or personal reasons are } \\
\text { not incompatible with the reasonableness of the job. Mobility requirements are determined } \\
\text { on the basis of remuneration (see Item } 6 \text { ). }\end{array}$ & 5 \\
\hline Greece & $\begin{array}{l}\text { Following registration as unemployed, the Vacancies Registry is examined to find out } \\
\text { whether there is a vacancy in the occupation in which the unemployed wishes to be } \\
\text { engaged. If there is no relevant vacancy, the vacancy search is expanded to other possible } \\
\text { jobs that the unemployed has declared. If any differences between the unemployed } \\
\text { person's characteristics and those required by the employer are due to the fact that the } \\
\text { unemployed has more qualifications than those required by the employer, the unemployed } \\
\text { person is asked whether he or she accepts to be placed in a vacant post for which fewer } \\
\text { qualifications are required. Provided they accept, they are placed accordingly. }\end{array}$ & 1 \\
\hline Hungary & $\begin{array}{l}\text { The unemployed has to accept an adequate job if offered one. Until } 1 / 1 / 2011 \text { this meant a } \\
\text { job that suited the qualification of the unemployed person, but after the mentioned date - } \\
\text { due to the new law that came into force - the offered job is no longer required to meet the } \\
\text { qualification of the unemployed. }\end{array}$ & 5 \\
\hline Ireland & The unemployed must accept all job offers that he/she is capable of doing. & 5 \\
\hline
\end{tabular}




\begin{tabular}{|c|c|c|}
\hline Country & Description & $\begin{array}{l}\text { Score } \\
2011\end{array}$ \\
\hline Israel & $\begin{array}{l}\text { Suitable work is defined as the type of work in which the unemployed person worked in the } \\
\text { three years preceding his unemployment, or any other work suiting his professional training } \\
\text { or education level. Unemployed persons aged under } 35 \text { years are required to accept any } \\
\text { work. }\end{array}$ & 3 \\
\hline Italy & $\begin{array}{l}\text { The unemployed must accept job offers fitting his professional skills, otherwise she/he } \\
\text { looses her/his unemployment seniority. }\end{array}$ & 4 \\
\hline Japan & $\begin{array}{l}\text { If the unemployed refuse a job offer which is introduced by PESO, benefits are stopped for } \\
\text { a month except if the employment to which the unemployed has been referred, or the } \\
\text { occupation for which he or she has been directed to take public vocational training, etc. is } \\
\text { not appropriate in the light of his or her abilities. }\end{array}$ & 5 \\
\hline Korea & $\begin{array}{l}\text { The unemployed can refuse job offers by the Job Centre in cases where the workplace } \\
\text { duties do not match with the skills and ability of the unemployed. However, in cases where } \\
\text { the unemployed keep looking for jobs in one single workplace or they continue to make } \\
\text { unacceptable requests given their career experience, age, skills and the labour market } \\
\text { conditions, unemployment benefits will be denied because these activities do not qualify as } \\
\text { active job seeking efforts. }\end{array}$ & 1 \\
\hline Lithuania & $\begin{array}{l}\text { Unemployment benefit recipients can refuse a job offer if it is in another occupation to their } \\
\text { previous job or to the occupation that they were trained to do. }\end{array}$ & 1 \\
\hline Luxembourg & $\begin{array}{l}\text { If the PES is not able to offer a job equivalent to his last employment to a jobseeker, any } \\
\text { proposed job offer should be in an activity related to prior occupation. The jobseeker's } \\
\text { training and work experience are taken into account. }\end{array}$ & 4 \\
\hline Malta & $\begin{array}{l}\text { The past experience (if any), qualifications and skills of the unemployed are taken into } \\
\text { account by the Employment Adviser when determining the unemployed person's job } \\
\text { preferences. An applicant shall not be allowed to register for less than two preferences. } \\
\text { Jobseekers can refuse a job offer if it necessitates fewer skills than his/her job preference if } \\
\text { they have been registered for less than } 12 \text { months. }\end{array}$ & 2 \\
\hline Netherlands & $\begin{array}{l}\text { In general, the unemployed should look for adequate work, the definition of which is } \\
\text { dependent on individual circumstances, such as the wage level before the person became } \\
\text { unemployed and the nature of the activities. The longer the person is unemployed, the } \\
\text { faster they have to accept a job at a lower education level. Non-binding guidelines suggest } \\
\text { that the unemployed should get six months to find a job in their former occupation, } \\
\text { educational- and income-level. After } 12 \text { months of unemployment, all kinds of work will be } \\
\text { considered as adequate. For early school leavers and students, every job is considered as } \\
\text { adequate. }\end{array}$ & 2 \\
\hline New Zealand & $\begin{array}{l}\text { The unemployed must not restrict their job search to vacancies within their own trade or } \\
\text { chosen occupation. }\end{array}$ & 5 \\
\hline Norway & $\begin{array}{l}\text { As a principal rule, unemployment benefit recipients have to be willing and able to take } \\
\text { whatever suitable work at the tariff wage. The duty to take whatever work implies that the } \\
\text { recipients have to take work that the person is physically and mentally suitable for. }\end{array}$ & 5 \\
\hline Poland & $\begin{array}{l}\text { The unemployed are required to accept any offer of suitable work and cannot restrict job } \\
\text { search to the occupational field or level of his/her professional qualifications or former job. } \\
\text { However, in practice the PES do not refer unemployed persons to jobs for which they might } \\
\text { be distinctly over-qualified. }\end{array}$ & 5 \\
\hline Portugal & $\begin{array}{l}\text { The unemployed must accept an offer of suitable employment, which consists of duties or } \\
\text { tasks which can be performed by the unemployed person, with particular regard to their } \\
\text { physical skills, educational qualifications and vocational training, skills and professional } \\
\text { experience, although not necessarily in the sector or activity or occupation of their previous } \\
\text { work. }\end{array}$ & 4 \\
\hline Romania & $\begin{array}{l}\text { The unemployed can refuse job offers if they do not fit their vocational training, level of } \\
\text { education or skills. }\end{array}$ & 1 \\
\hline $\begin{array}{l}\text { Slovak } \\
\text { Republic }\end{array}$ & $\begin{array}{l}\text { The unemployed person has to accept suitable employment, which is defined as } \\
\text { employment that takes in account the qualification and professional skills of unemployed } \\
\text { person, and considers the nature of recently performed work. }\end{array}$ & 4 \\
\hline Slovenia & $\begin{array}{l}\text { For the first three months of unemployment, the jobseeker can only be offered a job that } \\
\text { complies with their type and level of completed education (for a first-time jobseeker or } \\
\text { someone re-entering the labour force after a break of at least two years) or to the type and } \\
\text { level of required education for performing the job in which the person worked in the past } 12 \\
\text { months. After three months of unemployment, they may be offered a job with at most one } \\
\text { level lower of education that specified above, if there are no unemployed persons for which } \\
\text { such employment is considered appropriate. }\end{array}$ & 3 \\
\hline
\end{tabular}




\begin{tabular}{|c|c|c|}
\hline Country & Description & $\begin{array}{l}\text { Score } \\
2011\end{array}$ \\
\hline Spain & $\begin{array}{l}\text { During the first three months of unemployment, a job offer will be considered adequate if it } \\
\text { corresponds to the occupation indicated by the unemployed to the PES, their normal } \\
\text { profession or one that suits their skills and training. After three months of unemployment, a } \\
\text { job offer will be considered adequate if it corresponds to their most recent occupation. After } \\
\text { one year of unemployment, the unemployed must accept any job that the PES considers } \\
\text { appropriate for them. }\end{array}$ & 2 \\
\hline Sweden & $\begin{array}{l}\text { A job is considered suitable if, considering the supply of work, it takes into reasonable } \\
\text { consideration the benefit recipient's personal conditions, such as skills, experience and } \\
\text { family situation. The benefit recipient should get a reasonable time to adapt to new } \\
\text { circumstances such as occupational mobility. But the actual time (in days) is determined on } \\
\text { a case-by-case basis. }\end{array}$ & 4 \\
\hline Switzerland & $\begin{array}{l}\text { The unemployed must generally accept any job that they are capable of doing, even if it is } \\
\text { outside their previous profession. However, the unemployed has the right in the initial } \\
\text { period of unemployment to focus job search on jobs similar to his or her previous job, } \\
\text { subject to there being enough vacancies. From } 1 \text { April } 2011 \text {, this right does not extend to } \\
\text { those aged under } 30 \text {, who should accept any suitable job. }\end{array}$ & 4 \\
\hline Turkey & $\begin{array}{l}\text { The unemployed can search for jobs in up to } 10 \text { different occupations and is not required to } \\
\text { accept jobs that are not in his/her occupation list. However they cannot refuse a job offer if } \\
\text { it is in compliance with the unemployed person's occupation and provides a similar wage } \\
\text { and working conditions to their previous job. }\end{array}$ & 1 \\
\hline $\begin{array}{l}\text { United } \\
\text { Kingdom }\end{array}$ & $\begin{array}{l}\text { During the first } 13 \text { weeks of unemployment, the jobseeker can restrict their job search to } \\
\text { work in their normal occupation. After } 13 \text { weeks of unemployment, they can only restrict } \\
\text { their job search to their usual occupation if they can demonstrate reasonable prospects of } \\
\text { finding work. If not, they must be willing to accept a wider range of jobs. Similarly, a } \\
\text { claimant can base their salary requirements on their most recent remuneration package as } \\
\text { long as their are reasonable prospects of them obtaining that salary again. After } 6 \text { months } \\
\text { of unemployment, they cannot place any restrictions (other than the legal minimum) on the } \\
\text { salary they will accept. }\end{array}$ & 3 \\
\hline United States & $\begin{array}{l}\text { Within the limits of Federal law (see Item } 5 \text { ), states may take the previous occupation, } \\
\text { experience or qualification of the unemployed into account when determining suitable work. } \\
\text { Federal law requires that benefits not be denied for refusing to accept work if the wages, } \\
\text { hours or other conditions of work offered are substantially less favourable to the individual } \\
\text { than those prevailing for similar work in the locality. In some states, the unemployed is } \\
\text { given a specific time period in which they are allowed to restrict their search to their usual } \\
\text { occupation. However, after a period of unemployment (e.g. } 13 \text { weeks in New York, } 60 \text { days } \\
\text { in Florida) the unemployed must search for and accept offers of work in other occupations } \\
\text { for which they are suited. }\end{array}$ & 3 \\
\hline
\end{tabular}

Table B5. Demands on geographical mobility

\begin{tabular}{|c|c|c|}
\hline Country & Description & $\begin{array}{l}\text { Score } \\
2011 \\
\end{array}$ \\
\hline Australia & $\begin{array}{l}\text { A job would be regarded as within reasonable commuting distance if the journey between } \\
\text { the place of work and the jobseeker's home does not normally exceed } 90 \text { minutes by } \\
\text { whatever means of transport is normally available to the jobseeker. The commuting would } \\
\text { also be considered reasonable if a substantial number of people living in the same area as } \\
\text { the jobseeker regularly commute to their places of work. Reasonable travel times are } \\
\text { shorter for principal carer parents and jobseekers with partial work capacity. }\end{array}$ & 3 \\
\hline Austria & $\begin{array}{l}\text { The unemployed have to accept up to two hours of travelling time per day (in total to and } \\
\text { from work) to take up full-time work or } 1.5 \text { hours per day to take up part-time work. Under } \\
\text { specific circumstances (e.g. commuter regions) longer travel time must be accepted. }\end{array}$ & 2 \\
\hline Belgium & $\begin{array}{l}\text { In general, the unemployed can refuse a job offer if it involves more than } 4 \text { hours of daily } \\
\text { commuting time or more than } 12 \text { hours of daily absence from work, taking into account } \\
\text { available transport options. The job offer cannot be refused if the distance between home } \\
\text { and work is less than } 25 \mathrm{~km} \text {. For those older than } 50 \text {, the daily commuting time must not } \\
\text { exceed } 2 \text { hours and the daily absence from work must not exceed } 10 \text { hours. In exceptional } \\
\text { circumstances, the unemployed can refuse a job offer with shorter commuting time if the } \\
\text { commuting time is considered excessive due to the age or health of the person. }\end{array}$ & 3 \\
\hline
\end{tabular}




\begin{tabular}{|c|c|c|}
\hline Country & Description & $\begin{array}{l}\text { Score } \\
2011\end{array}$ \\
\hline Bulgaria & $\begin{array}{l}\text { Suitable jobs must be in the same location or within } 30 \mathrm{~km} \text { of their residence, as long as } \\
\text { there is adequate public transport. There are financial incentives for unemployed persons } \\
\text { who accept a job outside this area. }\end{array}$ & 2 \\
\hline Canada & $\begin{array}{l}\text { El claimants are not required to leave the area where they have always lived in order to } \\
\text { look for work. However, they are expected to make themselves available in the same area } \\
\text { as other workers residing in the same community. Claimants who restrict their availability to } \\
\text { a particular area of the city e.g. a city suburb, are allowed a reasonable period to restrict to } \\
\text { that geographical area provided that employment opportunities for which they are suited } \\
\text { exist in that area. However, if at the end of that reasonable period of time they have not } \\
\text { secured employment, these claimants will be required to expand the area in which they are } \\
\text { available for and seeking work. }\end{array}$ & 2 \\
\hline Cyprus & $\begin{array}{l}\text { There are no specific limitations on geographical mobility (it is at the discretion of the PES) } \\
\text { but the unemployed person can refuse a job that is away from his/her area of residence if } \\
\text { s/he proves that s/he has no transportation to get to the proposed job. The proposed job is } \\
\text { usually at the district of residence except if the unemployed person has no objection or } \\
\text { preference for a job in a different district. }\end{array}$ & 3 \\
\hline $\begin{array}{l}\text { Czech } \\
\text { Republic }\end{array}$ & $\begin{array}{l}\text { Suitable employment should take into account housing options, accessibility of the } \\
\text { workplace and the location of the person's spouse or registered partner. }\end{array}$ & 5 \\
\hline Denmark & $\begin{array}{l}\text { As a general rule, the unemployed person has to accept a total of } 3 \text { hours daily travel-to- } \\
\text { work time using public transportation. Special rules apply in special situations - e.g. where } \\
\text { the unemployed person lives in an area where acceptance of a longer travel-to-work time } \\
\text { will be necessary. After three months, the unemployed person must accept more than } 3 \\
\text { hours of total travel-to-work time. }\end{array}$ & 3.5 \\
\hline Estonia & $\begin{array}{l}\text { The jobseeker can refuse a job if the daily travel to and from work takes more than } 2 \text { hours } \\
\text { or the travel cost exceeds } 15 \% \text { of the monthly salary. }\end{array}$ & 2 \\
\hline Finland & $\begin{array}{l}\text { A job applicant is considered as having good cause to refuse work offered within his/her } \\
\text { commuting area (radius of up to } 80 \mathrm{~km} \text { from place of residence) if the daily travel-to-work } \\
\text { time would exceed three hours on average for a full-time job or two hours for a part-time } \\
\text { job. }\end{array}$ & 3 \\
\hline France & $\begin{array}{l}\text { After six months of unemployment, jobseekers must accept jobs that are located up to } \\
30 \mathrm{kms} \text { or one hour from their residence by public transport. }\end{array}$ & 1.5 \\
\hline Germany & $\begin{array}{l}\text { In terms of regional mobility jobs are considered reasonable only if the commuting time } \\
\text { does not exceed a total of two and a half hours relative to daily working hours of more than } \\
\text { six hours and two hours in the case of daily working hours of up to six. If in a region } \\
\text { distances are generally longer, the unemployed beneficiary must be prepared to accept } \\
\text { travelling such distances. Also, the employment agency can insist on the unemployed } \\
\text { beneficiary accepting employment if this involves his moving even if it cannot reasonably be } \\
\text { expected that he takes up employment within the above-mentioned commuting distance in } \\
\text { the first three months of unemployment. But the employment agency must take account of } \\
\text { important reasons given by the unemployed beneficiary (e.g. family ties) that rule out } \\
\text { moving. Financial consequences of a move must also be considered. In assessing the } \\
\text { costs of removal it should be kept in mind that the employment agency may encourage } \\
\text { taking up employment in a place other than the place of residence by paying the costs of } \\
\text { separate housekeeping and removal. }\end{array}$ & 3 \\
\hline Greece & $\begin{array}{l}\text { The unemployed person may be employed far from their permanent residence if the } \\
\text { protection of their family members is not jeopardised and if the unemployed have the ability } \\
\text { to settle at the place of employment, in case they are unable to return home on the same } \\
\text { day. The unemployed must accept a job in case the distance is up to } 30 \mathrm{~km} \text {, provided any } \\
\text { means of urban transport exist. }\end{array}$ & 3 \\
\hline Hungary & $\begin{array}{l}\text { The daily commute time back and forth between the work place and the residence by public } \\
\text { transport cannot exceed three hours, in the case of women taking care of a child under the } \\
\text { age of } 10 \text { and men taking care of a child alone under the age of ten. In case of disabled } \\
\text { persons the limit is two hours. }\end{array}$ & 3 \\
\hline Ireland & $\begin{array}{l}\text { Unemployed persons must accept all suitable job offers, within a reasonable/acceptable } \\
\text { distance. }\end{array}$ & 1 \\
\hline Israel & $\begin{array}{l}\text { Work is considered suitable if it does not require a change in the unemployed person's } \\
\text { place of residence (generally up to } 60 \mathrm{kms} \text { ). }\end{array}$ & 4 \\
\hline Italy & $\begin{array}{l}\text { The unemployed must accept job offers placed within a radius of } 50 \mathrm{~km} \text {, otherwise she/he } \\
\text { looses her/his unemployment seniority. }\end{array}$ & 3 \\
\hline
\end{tabular}




\begin{tabular}{|c|c|c|}
\hline Country & Description & $\begin{array}{l}\text { Score } \\
2011\end{array}$ \\
\hline Japan & $\begin{array}{l}\text { Employment Insurance benefit recipients are required to accept job offers proposed by } \\
\text { PESO except where a change in current domicile or address would be required in order to } \\
\text { take up the employment and it is found that the change would be difficult . In practice, } \\
\text { PESO are required not to introduce job offers to jobseekers that require changing } \\
\text { residence. }\end{array}$ & 4 \\
\hline Korea & $\begin{array}{l}\text { There is no specific requirement for geographical mobility. The unemployed are justified to } \\
\text { refuse job offers by the Job Centre if the referred workplace or establishments do not } \\
\text { provide accommodation or boarding services and it is deemed very difficult for the person } \\
\text { concerned to move to commutable areas near the establishment. }\end{array}$ & 1 \\
\hline Lithuania & $\begin{array}{l}\text { The unemployed is offered a job if the distance to the work place is no longer than three } \\
\text { hours using public transport, or two hours if he or she has a child aged under } 8 \text { years. }\end{array}$ & 3 \\
\hline Luxembourg & $\begin{array}{l}\text { A job offer will be considered as suitable if the jobseeker has a travel time of up to } 2.5 \text { per } \\
\text { day. If there is no means of transportation, public or organised by the employer, the } \\
\text { jobseeker cannot refuse to use his personal transportation, if available, provided the level of } \\
\text { remuneration covers expenses incurred for transportation, also taking account of applicable } \\
\text { geographical mobility aids which he may claim. A daily hours of travel less than } 2.5 \text { hours } \\
\text { may, in certain specific and exceptional cases, be regarded as excessive because of age or } \\
\text { physical condition of the worker or where the employment must be exercised in a remote } \\
\text { location from his residence. }\end{array}$ & 3 \\
\hline Malta & $\begin{array}{l}\text { Given Malta's limited geographical area, travel to work time and cost are not issues which } \\
\text { impede upon a jobseeker's acceptance of a job offer. However, unemployment benefit } \\
\text { recipients may refuse job offers available on islands which are not their resident island. }\end{array}$ & 4 \\
\hline Netherlands & $\begin{array}{l}\text { What is considered as adequate depends on individual circumstances. Non-binding } \\
\text { guidelines suggest that during the first six months of unemployment, travel time of less than } \\
2 \text { hours per day is considered adequate, unless in their former job longer travel times were } \\
\text { normal. After six months, travel time of maximum } 3 \text { hours a day is considered adequate. }\end{array}$ & 2.5 \\
\hline New Zealand & $\begin{array}{l}\text { There are no legislative requirements in relation to travel to work time and cost or } \\
\text { geographical mobility. However, unemployed people must generally accept a daily } \\
\text { transportation time of } 1-2 \text { hours per day. People are not required to take up a job in another } \\
\text { part of the country. }\end{array}$ & 2 \\
\hline Norway & $\begin{array}{l}\text { Jobseekers have to be willing to take up work anywhere in the country, and must be willing } \\
\text { to move or commute to participate in the labour market or worker where the work is, } \\
\text { regardless of distance. However, there are exceptions to this rule for those with reduced } \\
\text { health, aged over } 60 \text { years or with care obligations for children or partner, who can be } \\
\text { defined as a "local jobseeker". Local jobseekers have to accept a travel-to-work time up to } \\
\text { one hour each way. }\end{array}$ & 5 \\
\hline Poland & $\begin{array}{l}\text { The unemployed are not allowed to refuse a suitable job if daily commuting time does not } \\
\text { exceed } 3 \text { hours. }\end{array}$ & 3 \\
\hline Portugal & $\begin{array}{l}\text { The average time of travel between home and work should not exceed } 25 \% \text { of working } \\
\text { hours, except in situations where the beneficiary has minor children or depends, where the } \\
\text { percentage is } 20 \% \text {. The travel time can exceed } 25 \% \text { of working hours as long as it does not } \\
\text { exceed the travel time in the previous job. The cost of travel to work should not be more } \\
\text { than } 10 \% \text { of the gross monthly pay or the travel expenses of the previous job, unless the } \\
\text { employer pays for travel costs. }\end{array}$ & 3 \\
\hline Romania & $\begin{array}{l}\text { Unemployment benefit recipients cannot refuse a suitable job, irrespective of the } \\
\text { geographical location. If they accept a job that is more than } 50 \mathrm{~km} \text { away from home or } \\
\text { change their residence to another locality, they receive incentives granted in the form of a } \\
\text { bonus when they are hired. }\end{array}$ & 5 \\
\hline $\begin{array}{l}\text { Slovak } \\
\text { Republic }\end{array}$ & $\begin{array}{l}\text { The unemployed person must accept all suitable job offers. Unemployed persons who take } \\
\text { up work may be eligible for commuting subsidies for up to } 12 \text { months after starting the new } \\
\text { job or starting a new business, or a relocation subsidy if they relocate at least } 50 \mathrm{~km} \text { to take } \\
\text { up work. }\end{array}$ & 5 \\
\hline Slovenia & $\begin{array}{l}\text { In general, a job offer is considered adequate if the workplace is no further than a three } \\
\text { hour drive using public transport or transportation organised by the employer from the } \\
\text { person's place of residence and back. An unemployed person who lives alone in the same } \\
\text { household with children under } 15 \text { years is allowed to refuse job offers involving more than } 2 \\
\text { hours of commuting time. }\end{array}$ & 3 \\
\hline
\end{tabular}




\begin{tabular}{|c|c|c|}
\hline Country & Description & $\begin{array}{l}\text { Score } \\
2011\end{array}$ \\
\hline Spain & $\begin{array}{l}\text { A job offer will be considered adequate if it is located in the same location as the usual } \\
\text { residence of the unemployed person or in another location within a radius of } 30 \mathrm{kms} \text { from } \\
\text { their usual residence, provided that the return journey to work does not pass } 25 \% \text { of the } \\
\text { duration of the work day or that the cost of the journey does not exceed } 20 \% \text { of the monthly } \\
\text { salary, or when it is possible to find adequate accommodation in the new job's location. }\end{array}$ & 3 \\
\hline Sweden & $\begin{array}{l}\text { A job is considered suitable if the time-to-work and cost is reasonable. In practice, a } \\
\text { reasonable time-to-work is such that it results in an absence from home of not more than } \\
12 \text { hours per day, which means approximately } 1.5 \text { hours in each direction for a full-time } \\
\text { employee. }\end{array}$ & 3 \\
\hline Switzerland & $\begin{array}{l}\text { A job is not considered suitable if it requires travel of more than } 2 \text { hours each way ( } 4 \text { hours } \\
\text { in total) per day by public transport. If public transport is so poor as to dramatically reduce } \\
\text { the mobility of the unemployed, the use of a private vehicle may be required. }\end{array}$ & 3 \\
\hline Turkey & $\begin{array}{l}\text { The unemployed person cannot refuse a job offer if the workplace is in the same municipal } \\
\text { area. }\end{array}$ & 2 \\
\hline $\begin{array}{l}\text { United } \\
\text { Kingdom }\end{array}$ & $\begin{array}{l}\text { In the first } 13 \text { weeks of unemployment, the unemployed are expected to travel up to one } \\
\text { hour in each direction to find work by a route and means appropriate to their circumstances. } \\
\text { After } 13 \text { weeks of unemployment, they must broaden their search to extend the hours they } \\
\text { are willing to travel in each direction to find work to up to } 1.5 \text { hours in each direction. }\end{array}$ & 2.5 \\
\hline United States & $\begin{array}{l}\text { Within the limits of Federal law (see Item } 5 \text { ), states can decide what is taken into } \\
\text { consideration when defining suitable work. States typically take commuting time and/or } \\
\text { distance from the unemployed's residence into account when defining suitable work. Some } \\
\text { states specify that a job offer can be refused if the commuting time is excessive. In } \\
\text { California, one hour's travel time each way is not considered excessive, and in New York } \\
\text { one hour by private transportation and } 1.5 \text { hours by public transport is not considered } \\
\text { excessive. Longer commuting times may be considered normal in some areas or if } \\
\text { opportunities for work in the unemployed's occupation or locality are limited. }\end{array}$ & 3 \\
\hline
\end{tabular}

Table B6. Other valid reasons for refusing job offers

\begin{tabular}{|c|c|c|}
\hline Country & Description & $\begin{array}{l}\text { Score } \\
2011\end{array}$ \\
\hline Australia & $\begin{array}{l}\text { Work may be unsuitable for the jobseeker if it requires particular skills, experience or } \\
\text { qualifications that the person does not have, and appropriate training will not be provided } \\
\text { by the employer; may aggravate a pre-existing illness, disability or injury and medical } \\
\text { evidence has been provided; involves health or safety risks and would contravene an } \\
\text { occupational health and safety law; the jobseeker is a principal carer of a child or children } \\
\text { and appropriate care and supervision of the child(ren) is not available during the hours the } \\
\text { person would be required to work; the terms and conditions for the work are less generous } \\
\text { than the applicable statutory conditions; is the subject of industrial disputation; involves } \\
\text { enlistment in the Defence Force or the Reserve Forces; is unsuitable for any other reason } \\
\text { (e.g. on moral or religious grounds). }\end{array}$ & 3 \\
\hline Austria & $\begin{array}{l}\text { Employment is considered reasonable if it is appropriate to the physical abilities of the } \\
\text { unemployed person, does not endanger his/her health or morals, is appropriately } \\
\text { remunerated (at least } 80 \% \text { of previous remuneration in first } 120 \text { days of unemployment; at } \\
\text { least } 75 \% \text { for remainder of unemployment), is to be undertaken in an enterprise that is not } \\
\text { affected by strikes or lockouts and provided that statutory child care requirements can be } \\
\text { met. }\end{array}$ & 1 \\
\hline Belgium & $\begin{array}{l}\text { Other factors that can justify the refusal of a job offer are: physical or mental aptitude of the } \\
\text { unemployed; the family or personal situation of the unemployed; if the unemployed can } \\
\text { prove that they have another job which will start within } 8 \text { days; religious, philosophical or } \\
\text { ecological objections; if the job involves work at night (except if work at night is a } \\
\text { characteristic of the unemployed's profession); self-employment or if the salary offered is } \\
\text { less than the unemployment benefit. }\end{array}$ & 1 \\
\hline Bulgaria & All personal grounds are taken into account when deciding on suitable employment in the & 4 \\
\hline
\end{tabular}
first 18 months of unemployment. After 18 months, only health grounds apply. 


\begin{tabular}{|c|c|c|}
\hline Country & Description & $\begin{array}{c}\text { Score } \\
2011\end{array}$ \\
\hline Canada & $\begin{array}{l}\text { Unsuitable employment is that which: arrives as a result of a labour dispute; or at a lower } \\
\text { rate of earnings or on conditions less favourable than those normally observed in } \\
\text { collective/individual agreements or by good employers. In order not to be subject to a } \\
\text { disqualification, the claimant must show that a refusal of a suitable job was with good } \\
\text { cause. Good cause can stem from personal or family circumstances as well as from the } \\
\text { employment itself. }\end{array}$ & 3 \\
\hline Cyprus & $\begin{array}{l}\text { The unemployed person can refuse to accept a job offer is s/he has reasonable cause. For } \\
\text { example, this includes if s/he has brought a medical certificate that s/he cannot accomplish } \\
\text { a certain type of occupation and the job offer has to do with these limitations; s/he has } \\
\text { family or caring responsibilities and cannot take a job offer with certain job characteristics, } \\
\text { such as shift, night or weekend work; the wage or working conditions of the job offer are } \\
\text { below the usual rate for that job. Jobs offered by the PES are usually full-time jobs and any } \\
\text { other reasonable cause may be accepted at the discretion of the PES. A job is not } \\
\text { considered suitable if the job is vacant due to a strike or industrial dispute. }\end{array}$ & 3 \\
\hline $\begin{array}{l}\text { Czech } \\
\text { Republic }\end{array}$ & $\begin{array}{l}\text { Suitable employment is that with working hours of at least } 80 \% \text { of standard weekly hours } \\
\text { (50\% after one year of unemployment); has a contract for an indefinite period or for a fixed } \\
\text { term longer than } 3 \text { months; and corresponds to the state of health of the unemployed } \\
\text { person. Serious reasons for job refusal including caring for children or other dependents, } \\
\text { school or preschool attendance of children, the location or type of employment of the } \\
\text { spouse or registered partner, health reasons and other serious personal reasons such as } \\
\text { ethical, moral or religious reasons. }\end{array}$ & 3 \\
\hline Denmark & $\begin{array}{l}23 \text { valid reasons may justify a refusal to accept a job offer. The valid reasons relate to: } \\
\text { health problems, transportation problems, child care and other family-care obligations, } \\
\text { specific situations related to the job offer e.g. the reasonableness of the job offer (e.g. if the } \\
\text { terms of employment and wages are not usual for the occupation), the right to } \\
\text { supplementary benefits, etc., starting (more permanently) a new job, education, self- } \\
\text { employment or military service, retirement to early retirement pay. }\end{array}$ & 3 \\
\hline Estonia & $\begin{array}{l}\text { In the first } 20 \text { weeks of unemployment, the jobseeker can refuse a job if the salary is less } \\
\text { than } 60 \% \text { of the previous salary. From the } 21 \text { st week, the salary for full-time employment } \\
\text { must be higher than the unemployment benefit but not lower than the minimum wage. The } \\
\text { jobseeker can also refuse a job for health reasons or family obligations (in the first } 20 \\
\text { weeks, after that only very serious family circumstances will be taken into account). }\end{array}$ & 4 \\
\hline Finland & $\begin{array}{l}\text { The unemployed can refuse a job offer if the work is contrary to his/her religious beliefs or } \\
\text { conscience, if the job is to replace workers on strike or lockout, if the job is unsuitable } \\
\text { taking into account his/her state of health or if the job is part-time and the pay is less than } \\
\text { the unemployment benefit and potential adjusted unemployment benefit. In addition, the } \\
\text { unemployed can refuse a job offer outside their commuting area if the job is not of a full- } \\
\text { time, permanent nature that would guarantee an income, a suitable residence for the } \\
\text { unemployed person and his/her family is not available in the new locality or considering the } \\
\text { unemployed person's language skills or other weighty personal reasons. }\end{array}$ & 1 \\
\hline France & $\begin{array}{l}\text { Job offers can be refused on the grounds of the salary in the first three months of } \\
\text { unemployment. After three months, a job offer is considered reasonable if the salary is at } \\
\text { least } 95 \% \text { of the previous salary; } 85 \% \text { after six months of unemployment and at least equal } \\
\text { to the unemployment benefit after one year of unemployment. The family situation and } \\
\text { health of the jobseeker are also taken into account. }\end{array}$ & 3 \\
\hline Germany & $\begin{array}{l}\text { The unemployed may refuse a job offer by the employment agency if he can give good } \\
\text { reasons. This may, for instance, be the case if the unemployed is unable to accept the job } \\
\text { offer for health reasons. In specifying the reasonableness of a job, account must also be } \\
\text { taken of the income to be obtained. During the first three months of unemployment, jobs } \\
\text { are considered to be reasonable for the unemployed if earnings are not lower by more than } \\
20 \% \text { and during the following three months if earnings are not lower by more than } 30 \% \text { of } \\
\text { the previous wages which serve as the basis of unemployment benefits. After the first six } \\
\text { months of unemployment, jobs are considered to be reasonable if earnings are not lower } \\
\text { than the unemployment benefit. }\end{array}$ & 5 \\
\hline Greece & $\begin{array}{l}\text { If the unemployed person's physical and mental abilities are adequate, their health and } \\
\text { morals are not jeopardised, the remuneration is reasonable, the employment does not } \\
\text { impede their future advancement, and the distance of the job from their permanent } \\
\text { residence does not jeopardise the protection of their family members, then the unemployed } \\
\text { may be forced to engage in the offered job. }\end{array}$ & 3 \\
\hline
\end{tabular}




\begin{tabular}{|c|c|c|}
\hline Country & Description & $\begin{array}{l}\text { Score } \\
2011\end{array}$ \\
\hline Hungary & $\begin{array}{l}\text { If the unemployed person's health justifies his incapacity related to the job, if the amount of } \\
\text { the offered wage is below his/her unemployment benefit or minimum wage (if his/her } \\
\text { unemployment benefit is below the minimum wage). }\end{array}$ & 5 \\
\hline Ireland & $\begin{array}{l}\text { A job offer may be refused without losing the right to benefits where the job is: } \\
\text { (i) employment in a situation vacant as a consequence of a work stoppage due to a dispute; } \\
\text { (ii) employment in the district where he/she was last ordinarily employed at a rate of } \\
\text { remuneration lower, or on conditions less favourable, than those which he habitually } \\
\text { obtained in his usual employment in that district, or would have obtained had he continued } \\
\text { to be so employed, or } \\
\text { (iii) employment in any other district at a rate of remuneration lower, or on conditions less } \\
\text { favourable, than those generally observed in that district by agreement by associations of } \\
\text { employers and employees or, failing such agreement, than those generally recognised in } \\
\text { that district by good employers. }\end{array}$ & 5 \\
\hline Israel & $\begin{array}{l}\text { The wages offered in suitable work should be at least equal to the unemployment benefit } \\
\text { (this condition does not apply to unemployed persons under the age of } 35 \text { years). The work } \\
\text { should suit the condition of health of the unemployed person. }\end{array}$ & 5 \\
\hline Italy & $\begin{array}{l}\text { The unemployed cannot refuse to accept a job offer without losing her/his unemployment } \\
\text { seniority. }\end{array}$ & 5 \\
\hline Japan & $\begin{array}{l}\text { Unemployment benefit recipients can refuse a job offer or to participate in public vocational } \\
\text { training and other services without penalty in the following circumstances: where the job is } \\
\text { not appropriate in light of his/her abilities; where the wage offered by the employer is } \\
\text { unjustifiably low in comparison to the wage level usual for work of the same degree of skill } \\
\text { in the same kind of business in the same locality; where the job is to replace workers on } \\
\text { strike or lockout; or where there is other just cause. }\end{array}$ & 1 \\
\hline Korea & $\begin{array}{l}\text { Valid reasons for refusing job offers are if the wage level is unfairly and unduly low, if the } \\
\text { job does not suit the mental or physical abilities of the unemployed person (including health } \\
\text { or disabilities) or if the job is to replace workers on strike. }\end{array}$ & 3 \\
\hline Lithuania & $\begin{array}{l}\text { Valid reasons for refusing a job offer are family or personal reasons or poor } \\
\text { health/disability. }\end{array}$ & 5 \\
\hline Luxembourg & $\begin{array}{l}\text { A job offer is deemed appropriate if it is paid at a level at least equal to that of the full } \\
\text { unemployment benefit to which the jobseeker is entitled, and if the job is suitable for the } \\
\text { jobseeker's physical and mental abilities. A jobseeker who previously held a full-time job } \\
\text { can refuse a job offer of part-time work in the first } 12 \text { months of unemployment. A jobseeker } \\
\text { who was previously voluntarily part-time can refuse job with more hours per day or week } \\
\text { than their previous job. Family considerations, including the care of a child or children, } \\
\text { cannot be considered in assessing the appropriateness of the job offer unless they } \\
\text { constitute a particularly serious impediment (if so, the burden of proof is on the applicant). }\end{array}$ & 3 \\
\hline Malta & $\begin{array}{l}\text { Justifications for refusing to accept a job offer are evaluated on a case-by-case basis. } \\
\text { Refusal is justified in cases where a client provides relevant documents to support his/her } \\
\text { claim. Justifications may also include claims made by clients stating that they are medically } \\
\text { unfit for that particular occupation. Depending on a jobseeker's past working experiences } \\
\text { and previous salary band, he/she may refuse job offers that carry a salary corresponding to } \\
\text { the minimum wage if that client has been on the unemployment register for less than three } \\
\text { months. }\end{array}$ & \\
\hline Netherlands & $\begin{array}{l}\text { In principle a benefit recipient has to accept every job offer. A person that rejects a job offer } \\
\text { is to be sanctioned (reduction of the benefit). }\end{array}$ & 5 \\
\hline New Zealand & $\begin{array}{l}\text { A person has to demonstrate that they had a good and sufficient reason for refusing to } \\
\text { accept a job offer or participate in a particular programme or activity. The guiding principle } \\
\text { in determining good and sufficient reasons is one of reasonableness. Good and sufficient } \\
\text { reasons may include (but are not limited to), that the person: was temporarily medically } \\
\text { unfit, had a death or illness in the immediate family, had childcare arrangements that fell } \\
\text { through or had an unexpected event occur on that day. The person's individual } \\
\text { circumstances are taken into account before they are referred to a job or an activity to } \\
\text { ensure that they can realistically meet their obligations. Factors taken into account include: } \\
\text { access to childcare and other family commitments, religious beliefs, number of hours and } \\
\text { time of day, wages and whether the job is suitable. }\end{array}$ & 3 \\
\hline Norway & $\begin{array}{l}\text { Other reasons for refusing a job offer are if the unemployed person is not physically or } \\
\text { mentally suitable for the job or if the job is paid on a commission basis. }\end{array}$ & 5 \\
\hline
\end{tabular}




\begin{tabular}{|c|c|c|}
\hline Country & (2) & $\begin{array}{l}\text { Score } \\
2011\end{array}$ \\
\hline Poland & $\begin{array}{l}\text { The unemployed may refuse a job offer for various reasons that are not listed in the } \\
\text { regulations, but are in practice relatively limited (e.g. moral or religious reasons). The head } \\
\text { of the local government (starosta) decides whether the refusal is justified or not. } \\
\text { Unsuitability of the work on medical grounds may be proved by providing an appropriate } \\
\text { medical certificate held by the unemployed. }\end{array}$ & 5 \\
\hline Portugal & $\begin{array}{l}\text { During the first } 12 \text { months of unemployment, suitable employment must guarantee a gross } \\
\text { pay equal to or greater than the value of the unemployment benefit plus } 10 \% \text {. After } 12 \\
\text { months of unemployment, the pay must be equal or greater than the unemployment benefit. } \\
\text { The unemployed may also refuse a job offer or participation in an ALMP on the grounds of } \\
\text { illness or disability. }\end{array}$ & 5 \\
\hline Romania & $\begin{array}{l}\text { The unemployed can refuse a job if their health state does not allow them to do that kind of } \\
\text { work. }\end{array}$ & 5 \\
\hline $\begin{array}{l}\text { Slovak } \\
\text { Republic }\end{array}$ & $\begin{array}{l}\text { Unemployed can refuse a job offer if he/she has compelling reasons for refusal. Compelling } \\
\text { reasons are defined as follows: when the location and nature of employment of the spouse, } \\
\text { or location and nature of employment location and nature of employment preclude the } \\
\text { possibility to ensure escort for a child up to ten years of age to a pre-school establishment } \\
\text { or to school, state of health of unemployed, qualified by medical assessing and state of } \\
\text { health of close persons, qualified by statement of the attending physician or by decision of } \\
\text { a health care facility. Furthermore, suitable work is defined as work where the weekly } \\
\text { working hours are not less than one half of the determined weekly working hours. }\end{array}$ & 3 \\
\hline Slovenia & $\begin{array}{l}\text { The unemployed can refuse a job offer, if he/she takes he is seriously ill the job will be } \\
\text { injurious to his/her health) }\end{array}$ & 5 \\
\hline Spain & $\begin{array}{l}\text { The PES will also take into account the personal and professional circumstances of the } \\
\text { unemployed person, including the reconciliation of work and family life and the } \\
\text { characteristics of the proposed job. }\end{array}$ & 5 \\
\hline Sweden & $\begin{array}{l}\text { The unemployed can refuse a job for family reasons, medical/health reasons, if the wage is } \\
\text { less than } 90 \% \text { of previous income, if they have been promised work or if the workplace is } \\
\text { on an illegal strike. }\end{array}$ & 3 \\
\hline Switzerland & $\begin{array}{l}\text { Work is not considered suitable if it does not suit the age, personal situation or state of } \\
\text { health of the unemployed, if it is in an enterprise that is involved in an industrial dispute, or } \\
\text { if the work involves on-call work without a guarantee of a certain volume of work, }\end{array}$ & 3 \\
\hline Turkey & $\begin{array}{l}\text { If the offered job is not suitable with respect to the unemployed person's gender, physical } \\
\text { and health conditions. The unemployed cannot refuse a job offer if the job provides a } \\
\text { similar wage and working conditions to their previous job. }\end{array}$ & 3 \\
\hline $\begin{array}{l}\text { United } \\
\text { Kingdom }\end{array}$ & $\begin{array}{l}\text { The factors taken into account when determining whether a jobseeker has good cause for } \\
\text { refusing employment include: any agreed restrictions on the jobseeker's availability; } \\
\text { religious or conscientious objections sincerely held. }\end{array}$ & 3 \\
\hline United States & $\begin{array}{l}\text { All states provide for disqualification due to refusal of suitable work. The states differ, } \\
\text { however, in their approaches to defining what is suitable. Because of concerns for labour } \\
\text { standards, Federal law requires that compensation not be denied for refusing to accept } \\
\text { work in any of the following circumstances: (i) if the vacancy is due directly to a strike, lock- } \\
\text { out or other labour dispute; (ii) if the wages, hours or other conditions of work offered are } \\
\text { substantially less favourable to the individual than those prevailing for similar work in the } \\
\text { locality; (iii) if the individual is required to join, resign, refrain from or refrain from joining any } \\
\text { bona fide organisation as a condition of employment. Beyond this, states are free to use } \\
\text { any criteria to define the suitability of the job. As well as occupational and geographical } \\
\text { mobility requirements, most states define suitable work taking into account the degree of } \\
\text { risk to the unemployed's health, safety or morals and the unemployed's physical fitness for } \\
\text { the job. }\end{array}$ & 1 \\
\hline
\end{tabular}


Table B7. Proof of job-search activity

\begin{tabular}{|c|c|c|}
\hline Country & Description & $\begin{array}{l}\text { Score } \\
2011\end{array}$ \\
\hline Australia & $\begin{array}{l}\text { Generally the unemployed are required to report online, by phone, in writing or in person every } \\
\text { fortnight, answering questions about salient issues such as the employment vacancies they } \\
\text { have sought and changes in their circumstances. Each jobseeker is required to complete a } \\
\text { minimum number of job contacts each fortnight. The number is assessed on an individual } \\
\text { basis, starting with a benchmark level and then adjusted by taking into account local, individual } \\
\text { and general factors. The benchmark is generally set between } 6 \text { and } 10 \text { jobs per fortnight for } \\
\text { metropolitan areas and 4-6 for non-metropolitan areas. }\end{array}$ & 5 \\
\hline Austria & $\begin{array}{l}\text { Unemployed persons must report their job-search efforts in person to the PES every month on } \\
\text { average (this may vary depending on the labour market situation or their previously concluded } \\
\text { activity agreement). In most cases, the unemployed person must supply the name and address } \\
\text { of employers contacted and or supply written proof of applications. }\end{array}$ & 4 \\
\hline Belgium & $\begin{array}{l}\text { The unemployed must be available for work and actively search for work by, for example, } \\
\text { regularly consulting job vacancies, contacting potential employers and registering with } \\
\text { recruitment and temporary employment agencies. Job search efforts may be checked for all } \\
\text { jobseekers under the age of } 50 \text { years. In addition, after } 15 \text { months of unemployment (for those } \\
\text { aged under } 25 \text { ) or } 21 \text { months of unemployment (for those aged over } 25 \text { ), an interview will be } \\
\text { held to evaluate job search efforts. If the efforts are deemed sufficient, another interview will be } \\
\text { held } 16 \text { months later. If the efforts are not sufficient, an action plan will be drawn up detailing } \\
\text { job search efforts required, which is checked at an interview } 4 \text { months later. Jobseekers are } \\
\text { also required to report on the outcomes of referrrals to job vacancies. }\end{array}$ & 3 \\
\hline Bulgaria & $\begin{array}{l}\text { The unemployed provide only verbal information about their job seeking activities outside the } \\
\text { employment agency - internet, job announcements, etc. Evidence should be produced when in } \\
\text { the presence of a suitable job vacancy, the expert from the employment agency directs the } \\
\text { unemployed person. The frequency of consultations with the employment officer and the job- } \\
\text { search interviews is determined by the phase of unemployment. }\end{array}$ & 3 \\
\hline Canada & $\begin{array}{l}\text { Claimants must prove they are available for work and unable to obtain suitable employment } \\
\text { every day that they claim regular benefits. In addition, for regular benefits, claimants are } \\
\text { required to attest to their availability and capability for work on their biweekly reports. They can } \\
\text { be asked to prove that they are making reasonable and customary efforts to obtain suitable } \\
\text { employment. However there is no legislative provisions that govern the number and type of } \\
\text { applications for work that must be made, the format for a job search or the frequency of } \\
\text { reporting job-search activities. }\end{array}$ & 2 \\
\hline Cyprus & $\begin{array}{l}\text { The unemployed person is required to report at any office of the PES to state his/her interest in } \\
\text { finding work and register up to four occupations of interest. Once every } 30 \text { days the } \\
\text { unemployed person must re-appear at the PES to renew his/her request for work. The PES is } \\
\text { then responsible for job search. The unemployed person is not required to report any job- } \\
\text { search actions him/herself, however they have to attend any interviews scheduled for them by } \\
\text { the PES. The PES will check with the employer if the corresponding person attended the } \\
\text { interview or contacted the employer about a job. }\end{array}$ & 3 \\
\hline $\begin{array}{l}\text { Czech } \\
\text { Republic }\end{array}$ & $\begin{array}{l}\text { A jobseeker is obliged to apply for a job recommended by the Labour Office in set period of } \\
\text { time and report on the activity to the Labour Office. }\end{array}$ & 3 \\
\hline Denmark & $\begin{array}{l}\text { When an unemployed person attends a meeting in his unemployment insurance fund } \\
\text { concerning availability, he has to bring a plan for job-search activities (a plan that is formed at } \\
\text { the first meeting and revised every } 3 \text { months). He also has to bring a number of examples of } \\
\text { job applications. Finally, he has to be able to provide general information on his job-search } \\
\text { activities. Usually the unemployed person doesn't have to provide any further formal evidence } \\
\text { of job-search activities, unless requested by the unemployment insurance fund. If the } \\
\text { unemployed person has failed to sufficiently search for jobs or cannot provide general } \\
\text { information on his job-search activities, the unemployment insurance fund can require him to } \\
\text { provide information on and evidence of all job-search activities for a period of no more than } 3 \\
\text { months. }\end{array}$ & 2 \\
\hline Estonia & $\begin{array}{l}\text { The unemployed person must submit a list of companies contacted by him/her. Frequency of } \\
\text { reporting depends on the scheduled meetings with the officer of the Unemployment Insurance } \\
\text { Fund, and shall not be less than once a month. The required number of job-search actions is } \\
\text { not fixed by legislation, but depends on agreed targets, set by the person's Individual Action } \\
\text { Plan. Starting from } 1 \text { May } 2011 \text {, the jobseeker can contact the PES to provide proof of job- } \\
\text { search activity by telephone or computer rather than in person, if agreed by their PES } \\
\text { consultant. }\end{array}$ & 4 \\
\hline
\end{tabular}




\begin{tabular}{|c|c|c|}
\hline Country & Description & $\begin{array}{l}\text { Score } \\
2011\end{array}$ \\
\hline Finland & $\begin{array}{l}\text { The unemployed person and the Employment and Economic Development Office (TE Office) } \\
\text { draw up an employment plan, agreeing e.g. on the job-seeking and support services. It is } \\
\text { usually sufficient for the jobseeker to inform the TE Office that the tasks agreed in the plan } \\
\text { have been accomplished. However the plan may include an agreement that other evidence is } \\
\text { required, such as copies of job applications. }\end{array}$ & 2 \\
\hline France & $\begin{array}{l}\text { The unemployed must provide evidence of job search at interviews with an employment } \\
\text { counsellor once every month starting from the fourth month of unemployment. More frequent } \\
\text { interviews can be proposed for jobseekers who face particular difficulties finding work, such as } \\
\text { youth without qualifications, workers dismissed for economic reasons or long-term } \\
\text { unemployed. }\end{array}$ & 4 \\
\hline Germany & $\begin{array}{l}\text { An integration agreement concluded by the employment agency and the unemployed must } \\
\text { specify, for a period to be decided on, the placement efforts of the employment agency, the } \\
\text { unemployed person's own efforts and, to the extent that the relevant requirements are met, } \\
\text { future benefits under active employment promotion. The integration agreement is binding for } \\
\text { both sides, it underpins the responsibility of the employment agency towards the unemployed } \\
\text { and it makes the unemployed realise which efforts he himself is expected to make. The } \\
\text { agreement contains the intended individual placement strategy which must be updated } \\
\text { regularly or adapted to changes that occur; the strategy not only calls for the employment } \\
\text { agency to undertake placement efforts, but also requires the person out of work to intensively } \\
\text { look for a new job. There is no binding requirement to furnish evidence of the person's own } \\
\text { efforts, e.g. two applications per month. }\end{array}$ & 2 \\
\hline Greece & The unemployed are not required by legislation to provide evidence of job-search activity. & 1 \\
\hline Hungary & $\begin{array}{l}\text { The unemployed are not required to verify in writing their individual job-search activities. } \\
\text { However, if they are involved in job placement organised by the labour centre, they have to } \\
\text { show the job placement sheet to the employer, who fills the sheet, then the unemployed takes } \\
\text { the sheet back to the labour centre to confirm the results of the job placement. }\end{array}$ & 3 \\
\hline Ireland & $\begin{array}{l}\text { Job search is verified in availability reviews (interviews) that take place after } 7 \text { months, } 12 \\
\text { months and } 15 \text { months of unemployment. }\end{array}$ & 2 \\
\hline Israel & $\begin{array}{l}\text { The unemployed must report to the local Employment Service Office, generally once a week } \\
\text { (there are some exceptions - e.g. pregnant women report generally once per month). However, } \\
\text { there is no requirement to prove job-search activity. }\end{array}$ & 1 \\
\hline Italy & No requirement. & 1 \\
\hline Japan & $\begin{array}{l}\text { As a general rule, the unemployed must declare results of his/her job-search activities every } \\
\text { four weeks. }\end{array}$ & 4 \\
\hline Korea & $\begin{array}{l}\text { The unemployed are required to report once every four weeks on average to the Job Centre, } \\
\text { confirming their job-search activities during the recent benefit period on the standard job } \\
\text { seeking activity form and by providing a written list of employers they have contacted. }\end{array}$ & 4 \\
\hline Lithuania & $\begin{array}{l}\text { An unemployed person must inform the local labour exchange specialist about job-search } \\
\text { results, including looking for information about job vacancies on the internet, in the press or by } \\
\text { other means. An unemployed person receiving unemployment benefit must report on job- } \\
\text { search activity every month. An unemployed person not receiving unemployment benefit must } \\
\text { report on job-search activity every three months. }\end{array}$ & 4 \\
\hline Luxembourg & $\begin{array}{l}\text { Jobseekers are required to prove job search efforts when requested by the PES at monthly } \\
\text { interviews. Proof of job search takes the form of a list of employers contacted by the jobseeker. } \\
\text { However, there is no fixed frequency with which jobseekers must prove job search nor a } \\
\text { minimum number of job search activities that must be undertaken. }\end{array}$ & 2 \\
\hline Malta & $\begin{array}{l}\text { All unemployed jobseekers are obliged to draw up a Personal Action Plan (PAP), which } \\
\text { includes those steps necessary to assist them in finding employment. Once enrolled onto a } \\
\text { PAP, jobseekers agree to pursue a number of job-search activities on a weekly basis. PAP } \\
\text { review meetings are scheduled on a monthly basis during which jobseekers are requested to } \\
\text { provide a breakdown of job-search activities that they have undertaken. }\end{array}$ & 4 \\
\hline Netherlands & $\begin{array}{l}\text { Unemployed people make individual agreements with the PES about expected job seeking } \\
\text { activities. There is no specific requirement to prove the number of jobs applied for, but job } \\
\text { seeking activities such as visiting a job market, registering at a temporary work agency, job } \\
\text { interviews must be concrete and verifiable. }\end{array}$ & 4 \\
\hline
\end{tabular}




\begin{tabular}{|c|c|c|}
\hline Country & Description & $\begin{array}{l}\text { Score } \\
2011\end{array}$ \\
\hline $\begin{array}{l}\text { New } \\
\text { Zealand }\end{array}$ & $\begin{array}{l}\text { Unemployed can be required to check in and update on progress as often as required in } \\
\text { compliance with their work test obligations. This can be by phone, email or in person. } \\
\text { Guidelines recommend that the unemployed, if required to report on progress, should do so no } \\
\text { more than weekly. However, there are some situations where a person may be required to } \\
\text { report more frequently. In the first } 13 \text { weeks of unemployment, there are a minimum of four } \\
\text { contacts. The evidence required depends on the job-search activity that the unemployed } \\
\text { person was required to complete. It could include job applications, statements from employers } \\
\text { or a CV. }\end{array}$ & 4 \\
\hline Norway & $\begin{array}{l}\text { The unemployed can be required to provide evidence of job-search as a condition for } \\
\text { entitlement to unemployment benefit. }\end{array}$ & 2 \\
\hline Poland & $\begin{array}{l}\text { The unemployed must be able and ready to take up full-time employment, but there are } \\
\text { generally no formal job-search requirements apart from being registered as unemployed in a } \\
\text { district labour office, reporting to the labour office at designated dates to confirm availability } \\
\text { and receive information on employment and training opportunities and accept job offers, } \\
\text { training or other forms of support proposed by the labour office. The unemployed who are } \\
\text { considered to face special difficulties in the labour market (youth, older, low-skilled or } \\
\text { inexperienced jobseekers) are obliged to enter into an Individual Action Plan after } 180 \text { days of } \\
\text { unemployment, which can set out additional job-search requirements. }\end{array}$ & 1 \\
\hline Portugal & $\begin{array}{l}\text { Unemployment benefit recipients are obliged to report bi-monthly to the Job Centre and prove } \\
\text { their active job-search efforts. The minimum steps required to fulfil the duty of actively seeking } \\
\text { employment are defined in the Employment Personal Plan. }\end{array}$ & 5 \\
\hline Romania & $\begin{array}{l}\text { Unemployed persons must prove that they have reported to ask for a job at the county or } \\
\text { Bucharest employment agency, where they are registered, on a monthly basis. They can also } \\
\text { report to other employment services providers for job mediation. }\end{array}$ & 4 \\
\hline $\begin{array}{l}\text { Slovak } \\
\text { Republic }\end{array}$ & $\begin{array}{l}\text { The jobseeker is obliged to actively seek employment and personally prove active job search } \\
\text { to the Office of Labour, Social Affairs and Family at least once per calendar month, typically } \\
\text { once in seven calendar days for long term unemployed, once a month for unemployed taking } \\
\text { part in any type of ALMP, one a fortnight for remaining unemployed. Jobseekers who provide } \\
\text { evidence of temporary incapacity and pregnant jobseekers who provide evidence of their } \\
\text { expected date of delivery are exempted from providing proof of job-search activity. }\end{array}$ & 5 \\
\hline Slovenia & $\begin{array}{l}\text { The unemployed are required to provide evidence of job-search activities. They should } \\
\text { regularly apply for vacancies, respond to referrals from the Employment Service, attend } \\
\text { interviews and carry out all activities agreed in the employment plan. Evidence of active job } \\
\text { search could include confirmation from employers in response to referrals, copies of } \\
\text { applications for vacancies, data obtained from official records and records from the jobseeker's } \\
\text { employment diary. Activities are determined in the individual employment plan for each } \\
\text { unemployed person, therefore it is not possible to give precise information on the frequency of } \\
\text { reporting. }\end{array}$ & 4 \\
\hline Spain & $\begin{array}{l}\text { The unemployed sign an "activity commitment", in which they promise to actively look for work, } \\
\text { accept suitable job offers and participate in ALMPs to improve their employability. If referred to } \\
\text { a job vacancy by the PES, the unemployed must submit within } 5 \text { days proof that they attended } \\
\text { the interview in the location and date indicated. }\end{array}$ & 3 \\
\hline Sweden & The unemployment benefit recipient does not need to provide evidence of job-search activity. & 1 \\
\hline Switzerland & $\begin{array}{l}\text { The unemployed should provide proof of job search to the Regional Employment Office each } \\
\text { month. The quality and quantity of job search required by each person is determined according } \\
\text { to their individual circumstances, depending on the labour market situation and personal } \\
\text { factors such as age, qualifications, geographical mobility, language problems, etc. }\end{array}$ & 4 \\
\hline Turkey & $\begin{array}{l}\text { All unemployed should be registered with the Employment Agency as unemployed and should } \\
\text { perform all job-search activities. Since both the ALMPs and job-search activities are run by the } \\
\text { Turkish Employment Agency, there is an automatic check of job-search activities when the } \\
\text { unemployed are referred to a job vacancy. }\end{array}$ & 3 \\
\hline $\begin{array}{l}\text { United } \\
\text { Kingdom }\end{array}$ & $\begin{array}{l}\text { The unemployed participate in Fortnightly Jobsearch Reviews (FJRs). The FJR provides } \\
\text { regular opportunities to make sure people are actively seeking work and remain entitled to } \\
\text { benefits. The advisor will discuss the unemployed person's job-search activity including any } \\
\text { support they may need to enhance this and will use the Job Search Agreement, determined at } \\
\text { an initial interview when the jobseeker first makes a claim, to establish their job goals, review } \\
\text { the steps they agreed to take including asking what steps they have taken to look for work. } \\
\text { The evidence collected is then logged on to the system to show that eligibility has been met. }\end{array}$ & 5 \\
\hline
\end{tabular}




\begin{tabular}{|c|c|c|}
\hline Country & Description & $\begin{array}{c}\text { Score } \\
2011\end{array}$ \\
\hline $\begin{array}{l}\text { United } \\
\text { States }\end{array}$ & $\begin{array}{l}\text { Regular employer contacts are required in many states, and the actual number of required } \\
\text { contacts per week varies between one and five. Whether or not a minimum number of job- } \\
\text { search activities is required is determined by state law and procedure. Ul claimants are to } \\
\text { maintain a record of their job-search contacts and they must provide evidence of their job- } \\
\text { search activities if their claim is randomly selected for audit. In the seven largest states, } \\
\text { unemployed are not required to regularly prove job search, but must keep records of job } \\
\text { search to be shown upon request. }\end{array}$ & 2 \\
\hline
\end{tabular}

Table B8. Sanctions for refusing job offers or ALMP participation

\begin{tabular}{|c|c|c|}
\hline Country & Description & $\begin{array}{l}\text { Score } \\
2011\end{array}$ \\
\hline Australia & $\begin{array}{l}\text { A jobseeker who refuses a suitable job without a reasonable excuse may have an 8-week } \\
\text { penalty imposed. A jobseeker commits a connection failure if, without a reasonable excuse, } \\
\text { they: fail to attend an appointment, fail to enter into an EPP, or fail to meet job-search } \\
\text { requirements. There is no penalty for a connection failure. Instead, the jobseeker is given a } \\
\text { reconnection requirement. The reconnection requirement will depend on the basis for the } \\
\text { connection failure and will be: attendance at a further appointment, to complete a jobseeker } \\
\text { diary or another jobseeker diary, or to enter into the EPP. }\end{array}$ & 1.5 \\
\hline Austria & $\begin{array}{l}\text { If an unemployed person does not accept a reasonable job offer, the payment of benefits } \\
\text { from the unemployment insurance scheme is suspended for as long as the job is refused, } \\
\text { or in any event, for six weeks. Duration of benefits is shortened accordingly. }\end{array}$ & 2 \\
\hline Belgium & $\begin{array}{l}\text { The penalty for refusing a suitable job, not attending the PES without sufficient justification, } \\
\text { not attending a job interview after a referral from the PES or stopping or failing an } \\
\text { integration course due to the attitude of the unemployed is a suspension of benefits for } 4-52 \\
\text { weeks. Typical sanction is } 10-14 \text { weeks. The penalty for refusing to undertake an } \\
\text { integration course proposed by the PES is total suspension of unemployment benefit. }\end{array}$ & 3 \\
\hline Bulgaria & $\begin{array}{l}\text { The decline of a job offer by the unemployed person without good reason serves as } \\
\text { sufficient grounds for termination of the registration at the employment agency, which } \\
\text { includes the right to use its services. Other reasons for termination of registration include } \\
\text { failure to follow the employment officer's recommendations, failure to take the actions or } \\
\text { keep up with the timetable and schedule of visits included in the action plan, refusal to be } \\
\text { included in programmes, employment measures and adult training. Persons will become } \\
\text { eligible for subsequent registration at the employment agency not earlier than } 6 \text { months } \\
\text { after termination of the previous registration. }\end{array}$ & 4 \\
\hline Canada & $\begin{array}{l}\text { A claimant who has not applied for, has neglected to avail themselves of or has refused an } \\
\text { offer of suitable employment is subject to a disqualification from benefits for a period } \\
\text { ranging from } 7-12 \text { weeks. A claimant who fails to take action on a referral intended to assist } \\
\text { them to find suitable employment is subject to a disqualification of } 1-6 \text { weeks. }\end{array}$ & 2 \\
\hline Cyprus & $\begin{array}{l}\text { If the unemployed person refuses to submit a claim, refuses to accept a suitable job offer } \\
\text { without reasonable cause, refuses or neglected occupational training proposed by the } \\
\text { Director of Social Insurance Services without reasonable cause, fails to attend a job } \\
\text { interview without reasonable cause or deliberate failure of a job interview, then the payment } \\
\text { of the benefit may be postponed for up to six weeks. }\end{array}$ & 2 \\
\hline $\begin{array}{l}\text { Czech } \\
\text { Republic }\end{array}$ & $\begin{array}{l}\text { The Labour Office can remove the jobseeker from the register of jobseekers for a period of } \\
6 \text { months for (among other things) failing to take up suitable employment, refusing to } \\
\text { commence or attend an agreed training course or fails to cooperate with the Labour Office. }\end{array}$ & 4 \\
\hline Denmark & $\begin{array}{l}\text { The person is quarantined for } 3 \text { weeks where he would otherwise have been entitled to } \\
\text { unemployment benefits. }\end{array}$ & 1 \\
\hline Estonia & $\begin{array}{l}\text { The payment of unemployment allowance shall be suspended for a period of ten days if the } \\
\text { unemployed person refused suitable work for the first time without a good reason. }\end{array}$ & 1 \\
\hline Finland & $\begin{array}{l}\text { If an unemployed person refuses a job offer without good cause, entitlement to } \\
\text { unemployment benefit is usually lost for a period of } 60 \text { days. Refusal, without good cause, } \\
\text { of services offered by the TE Office usually results in loss of unemployment benefit for a } \\
\text { period of } 60 \text { days. }\end{array}$ & 2 \\
\hline France & $\begin{array}{l}\text { There is no penalty for refusing a reasonable job offer for the first time (sanctions apply } \\
\text { after two or more refusals). The refusal of a service offered by the public employment } \\
\text { service, such as participation in an ALMP, is liable to a } 20 \% \text { reduction in unemployment } \\
\text { benefit for two months. }\end{array}$ & 1 \\
\hline
\end{tabular}




\begin{tabular}{|c|c|c|}
\hline Country & Description & $\begin{array}{l}\text { Score } \\
2011\end{array}$ \\
\hline Germany & $\begin{array}{l}\text { In the case of unemployed persons who refuse a job offer by the employment agency or } \\
\text { participation in an integration programme without good reasons, benefits will be suspended } \\
\text { for three weeks (first refusal). Moreover, the period of entitlement to benefits will be cut by } \\
\text { the number of days for which benefits are suspended. }\end{array}$ & 1 \\
\hline Greece & $\begin{array}{l}\text { The unemployed person ceases to receive unemployment benefit if he/she does not accept } \\
\text { a job offer or refuses to participate in an ALMP. }\end{array}$ & 5 \\
\hline Hungary & $\begin{array}{l}\text { The unemployment benefit (as well as other benefits) of the person is terminated in this } \\
\text { case, and his/her file is deleted from the register of unemployed persons. The concerned } \\
\text { person can register again after } 2 \text { months. }\end{array}$ & 2 \\
\hline Ireland & Benefits are suspended for refusing job offer. & 5 \\
\hline Israel & $\begin{array}{l}\text { Refusal to accept suitable work rules out payment of unemployment benefit for } 90 \text { days } \\
\text { from the refusal and } 30 \text { unemployment days are deducted from the remainder of the } \\
\text { maximum period for which payment is due on the day of refusal. }\end{array}$ & 4 \\
\hline Italy & The unemployed who refuses to accept a job offer loses his/her unemployment seniority. & 5 \\
\hline Japan & $\begin{array}{l}\text { If the unemployed refuses a job offer introduced by PESO or public vocational training } \\
\text { instructed by the head of PESO without good reasons, benefits are stopped for a month. }\end{array}$ & 1 \\
\hline Korea & $\begin{array}{l}\text { Unemployment benefits are suspended for } 2 \text { weeks when the unemployed refuse job offers } \\
\text { or vocational guidance from the Job Centre without justifiable reason, and for } 4 \text { weeks } \\
\text { when the unemployed refuse to attend vocational training courses without justification. }\end{array}$ & 1 \\
\hline Lithuania & $\begin{array}{l}\text { Unemployment benefit is suspended if the unemployed refuse a suitable job offer, refuse } \\
\text { for no good reason to participate in an ALMP laid down in his/her employment plan, fail to } \\
\text { arrive at a set time at the PES to accept a job offer or participate in an ALMP laid down in } \\
\text { his/her employment plan or refuse to undergo a health check offered by the PES to } \\
\text { establish suitability for work. Persons participating in ALMPs who lose their unemployment } \\
\text { status can re-register at the PES no earlier than six months after the suspension. }\end{array}$ & 4 \\
\hline Luxembourg & $\begin{array}{l}\text { An unemployment benefit recipient who refuses without justification a suitable job offer or to } \\
\text { participate in an ALMP loses rights to unemployment benefit. }\end{array}$ & 5 \\
\hline Malta & $\begin{array}{l}\text { When a registered unemployed person refuses a job offer or an ALMP placement without a } \\
\text { justifiable cause he/she will be required to fill in a Justification Form together with any } \\
\text { supporting documentation that explains the motive behind such action. If the unemployed } \\
\text { person's objection is not upheld, the jobseeker is moved to Part } 2 \text { of the unemployment } \\
\text { register for six months, thus losing entitlement to benefits. }\end{array}$ & 4 \\
\hline Netherlands & $\begin{array}{l}\text { The unemployed will be penalised if they do not sufficiently look for work or hamper the } \\
\text { process of finding adequate work. The sanction will be } 25 \% \text { of the benefit the person } \\
\text { receives for a period of at least } 4 \text { months. }\end{array}$ & 1 \\
\hline New Zealand & $\begin{array}{l}\text { If a person refuses a job offer or refuses to participate in an activity to which they have } \\
\text { been referred without good and sufficient reason, their benefit is reduced by } 50 \% \text { until such } \\
\text { time as they re-comply. If they do not re-comply within four weeks, then the benefit is } \\
\text { reduced by a further } 50 \% \text { until such time as they re-comply. }\end{array}$ & 1 \\
\hline Norway & $\begin{array}{l}\text { If a jobseeker refuses a job offer or ALMP placement, he/she loses entitlement to benefits } \\
\text { for eight weeks. }\end{array}$ & 2 \\
\hline Poland & $\begin{array}{l}\text { The unemployed loses his/her status for } 120 \text { days when refusing to take up employment, } \\
\text { training or other forms of support without a justified reason. In that case, the unemployed } \\
\text { simultaneously loses the right to the unemployment benefit. }\end{array}$ & 4 \\
\hline Portugal & $\begin{array}{l}\text { Registration at the Job Centre and entitlement to unemployment benefits is cancelled by } \\
\text { the following unjustified actions: refusal of suitable employment; refusal to participate in } \\
\text { vocational training, subsidised employment or other ALMPs, refusal to accept a Personal } \\
\text { Employment Plan or by a second failure to provide proof of active job search. }\end{array}$ & 5 \\
\hline Romania & $\begin{array}{l}\text { Unemployed persons who refuse an adequate job and have refused to attend services for } \\
\text { employment encouragement offered by employment agencies do not receive } \\
\text { unemployment benefit. }\end{array}$ & 5 \\
\hline $\begin{array}{l}\text { Slovak } \\
\text { Republic }\end{array}$ & $\begin{array}{l}\text { The Office will remove the jobseeker from the register of jobseeker from the day of } \\
\text { detecting his/her lack of cooperation, which includes refusal of suitable employment, refusal } \\
\text { to participate or early termination of participation in ALMPs without noteworthy excuses } \\
\text { (with the exception of refusal to participate in education and preparation for the labour } \\
\text { market). In case of removal of the jobseeker from the register of jobseekers, the jobseeker } \\
\text { loses entitlement to unemployment benefit. }\end{array}$ & 5 \\
\hline Slovenia & $\begin{array}{l}\text { If a person refuses to participate in an ALMP, refuses a suitable or appropriate employment } \\
\text { or an interview for a job or is not seeking to gain employment or refuses to sign an } \\
\text { employment plan, they are not eligible for unemployment benefit. }\end{array}$ & 5 \\
\hline
\end{tabular}




\begin{tabular}{|c|c|c|}
\hline Country & Description & $\begin{array}{l}\text { Score } \\
2011\end{array}$ \\
\hline Spain & $\begin{array}{l}\text { Refusing an adequate job offer without good cause or refusing to participate in an ALMP } \\
\text { without justification is considered a serious administrative offence and for the first offence } \\
\text { will result in a loss of benefits for three months. }\end{array}$ & 3 \\
\hline Sweden & If a job offer is refused the benefit will be reduced by $25 \%$ for 40 benefit days ( 8 weeks). & 1 \\
\hline Switzerland & $\begin{array}{l}\text { Refusing a suitable job offer will result in a benefit suspension of } 31-60 \text { benefit days }(6-12 \\
\text { weeks). }\end{array}$ & 2.5 \\
\hline Turkey & $\begin{array}{l}\text { If the unemployed person does not have a good cause, unemployment benefit will be } \\
\text { suspended and the rest of the benefit term will be abolished. }\end{array}$ & 5 \\
\hline $\begin{array}{l}\text { United } \\
\text { Kingdom }\end{array}$ & $\begin{array}{l}\text { A variable sanction of } 1-26 \text { weeks (depending on the circumstances of the case) will apply } \\
\text { when a jobseeker refuses employment without good cause. A fixed-length sanction of } 2 \\
\text { weeks (in the first instance) will apply when a jobseeker contributes to their own } \\
\text { unemployment without good cause by refusing a place on a training scheme or } \\
\text { employment programme. }\end{array}$ & 2 \\
\hline United States & $\begin{array}{l}\text { The reason for refusing the job offer is examined. In general, individuals will be disqualified } \\
\text { from receiving UI benefits if they refuse suitable work. The specific sanctions vary from } \\
\text { state to state. In the seven largest states, the sanction is disqualification until the } \\
\text { unemployed finds a new job. There is no requirement to accept placement in an ALMP to } \\
\text { remain eligible for unemployment benefits. }\end{array}$ & 5 \\
\hline
\end{tabular}

Table B9. Sanctions for repeated refusal of job offers or ALMP participation

\begin{tabular}{|c|c|c|}
\hline Country & Description & $\begin{array}{l}\text { Score } \\
2011\end{array}$ \\
\hline Australia & $\begin{array}{l}\text { Persistent non-compliance with participation requirements ( } 3 \text { or more failures in six } \\
\text { months) can result in a serious failure penalty, which results in a suspension of the benefit } \\
\text { for } 8 \text { weeks. There is no additional penalty for refusing a suitable job offer more than once. }\end{array}$ & 2 \\
\hline Austria & $\begin{array}{l}\text { The period of suspension may last for up to eight weeks in case of repeated refusal to } \\
\text { accept reasonable job offers. }\end{array}$ & 2 \\
\hline Belgium & $\begin{array}{l}\text { If an unemployed person refuses a second suitable job offer in the } 12 \text { months following a } \\
\text { suspension of unemployment benefit, they lose their right to unemployment benefit and do } \\
\text { not regain their rights until after working for sufficient number of days. If the first offence } \\
\text { resulted only in a warning or the first suspension was more than } 12 \text { months previously, } \\
\text { then this sanction does not apply. }\end{array}$ & 5 \\
\hline Bulgaria & The sanction is the same each time a job offer is refused. & 4 \\
\hline Canada & $\begin{array}{l}\text { Each incident of refusal of employment is taken into consideration on its individual merits } \\
\text { with no cumulative or escalating effect. }\end{array}$ & 2 \\
\hline Cyprus & $\begin{array}{l}\text { If the unemployed person has refused a job offer repeatedly (at least three times) without } \\
\text { reasonable cause, then the person is no longer considered willing to work and is no longer } \\
\text { entitled to unemployment benefit. }\end{array}$ & 3.5 \\
\hline $\begin{array}{l}\text { Czech } \\
\text { Republic }\end{array}$ & The sanction is the same each time a job offer is refused. & 4 \\
\hline Denmark & $\begin{array}{l}\text { If the unemployed person quits a job or an employability enhancement measure or refuses } \\
\text { a job offer or an ALMP placement without a valid reason two times within a } 12 \text { month } \\
\text { period he forfeits his or her right to unemployment benefits until he has worked in a regular } \\
\text { job for at least } 300 \text { hours within a } 12 \text { week period. }\end{array}$ & 5 \\
\hline Estonia & $\begin{array}{l}\text { If the unemployed person refuses to accept, without a good reason, a suitable job for the } \\
\text { second time, the unemployment allowance will be terminated. After a third refusal, his/her } \\
\text { registration as an unemployed person will be terminated. }\end{array}$ & 5 \\
\hline Finland & $\begin{array}{l}\text { If an unemployed person has repeatedly behaved in a manner deemed inappropriate from } \\
\text { a labour policy perspective, he/she loses entitlement to unemployment benefit until further } \\
\text { notice. The established interpretation of repeatedly is the second instance of inappropriate } \\
\text { behaviour within a period of approximately one year. Entitlement to benefit will be restored } \\
\text { once the jobseeker becomes employed, participates in certain services provided by the TE } \\
\text { Office or begins full-time studies for a minimum period of } 3 \text { months. }\end{array}$ & 5 \\
\hline France & $\begin{array}{l}\text { The refusal of two reasonable job offers results in cancellation of the unemployment } \\
\text { benefit for a period of two months. In case of repeated breaches, benefits may be } \\
\text { removed for } 2-6 \text { months or even permanently. Repeated refusal of services offered by the } \\
\text { PES can lead to a reduction in the unemployment benefit by } 50 \% \text { for } 2-6 \text { months, or it may } \\
\text { even be permanently suspended. }\end{array}$ & 2 \\
\hline
\end{tabular}




\begin{tabular}{|c|c|c|}
\hline Country & Description & $\begin{array}{l}\text { Score } \\
2011\end{array}$ \\
\hline Germany & $\begin{array}{l}\text { In the case of unemployed persons who refuse a job offer by the employment agency or } \\
\text { participation in an integration without good reasons, benefits will be suspended for six } \\
\text { weeks (second refusal) or twelve weeks (any subsequent refusal). Moreover, the period of } \\
\text { entitlement to benefits will be cut by the number of days for which benefits are suspended. }\end{array}$ & 2.5 \\
\hline Greece & The unemployment benefit has already been suspended after the first refusal. & 5 \\
\hline Hungary & $\begin{array}{l}\text { No additional sanctions exist for repeatedly refusing a job offer. The same sanction } \\
\text { applies as for the first refusal ( } 2 \text { months' suspension of benefits). }\end{array}$ & 2 \\
\hline Ireland & Same consequence as for initial refusal of job offer. & 5 \\
\hline Israel & $\begin{array}{l}\text { There are no special sanctions, but if there are recurring refusals, the recurring delay of } 90 \\
\text { days may lead to the end of the unemployment year and the } 30 \text { unemployment days } \\
\text { deducted for each refusal may eventually lead to the negation of the entire maximum } \\
\text { period of entitlement. }\end{array}$ & 4 \\
\hline Italy & The unemployment benefit has already been suspended after the first refusal. & 5 \\
\hline Japan & The same sanction applies as in the first case of refusal. & 1 \\
\hline Korea & $\begin{array}{l}\text { Unemployment benefits are suspended until the unemployed take in the guidance, job } \\
\text { offers and other advice from the Job Centre. }\end{array}$ & 4 \\
\hline Lithuania & $\begin{array}{l}\text { If the unemployed person repeatedly refuses job offers or ALMP participation, the same } \\
\text { sanction applies again. }\end{array}$ & 4 \\
\hline Luxembourg & Unemployment benefits have already been suspended after the first refusal. & 5 \\
\hline Malta & $\begin{array}{l}\text { No special sanctions are applied when the unemployed person refuses a job offer or an } \\
\text { ALMP placement for more than one time. The same sanction applies as for the first } \\
\text { refusal. }\end{array}$ & 4 \\
\hline Netherlands & $\begin{array}{l}\text { If the unemployed person receives a sanction and within a period of } 2 \text { years neglects the } \\
\text { same obligation, the sanction will increase to } 50 \% \text {. }\end{array}$ & 1 \\
\hline $\begin{array}{l}\text { New } \\
\text { Zealand }\end{array}$ & $\begin{array}{l}\text { For a second failure to meet work obligations, the benefit is suspended until such time as } \\
\text { they re-comply. For a third failure, the benefit is cancelled. A person whose benefit is } \\
\text { cancelled is not entitled to receive it for } 13 \text { weeks from the date of cancellation and has to } \\
\text { reapply and establish their eligibility. The suspension and cancellation only apply to a } \\
\text { portion of the benefit if the person has a spouse or partner or the couple have children. }\end{array}$ & 3 \\
\hline Norway & $\begin{array}{l}\text { Repeated refusals will result in extended sanctions. Two refusals will result in } 12 \text { weeks } \\
\text { repeal of unemployment benefits and three refusals will result in } 26 \text { weeks repeal. }\end{array}$ & 4 \\
\hline Poland & $\begin{array}{l}\text { After the second or third unjustified refusal of employment or ALMP participation without a } \\
\text { justified reason, the unemployed loses his/her status and unemployment benefit } \\
\text { entitlement for } 180 \text { days or } 270 \text { days respectively. Periods without status decrease the } \\
\text { length of entitlement to unemployment benefit after the next registration. }\end{array}$ & 4 \\
\hline Portugal & The unemployment benefit has already been suspended after the first refusal. & 5 \\
\hline Romania & The unemployment benefit has already been suspended after the first refusal. & 5 \\
\hline $\begin{array}{l}\text { Slovak } \\
\text { Republic }\end{array}$ & The unemployment benefit has already been suspended after the first refusal. & 5 \\
\hline Slovenia & $\begin{array}{l}\text { The unemployment benefit has already been suspended after the first refusal of an } \\
\text { appropriate and/or suitable job offer. }\end{array}$ & 5 \\
\hline Spain & $\begin{array}{l}\text { The unemployment benefit will be suspended for } 6 \text { months if the unemployed refuses a } \\
\text { job offer or to participate in an ALMP twice. A third refusal entails the loss of the } \\
\text { unemployment benefit. }\end{array}$ & 4.5 \\
\hline Sweden & $\begin{array}{l}\text { If a job offer is refused a second time the benefit will be reduced by } 50 \% \text { for } 40 \text { benefit } \\
\text { days. The third time a job offer is refused the recipient will be suspended. }\end{array}$ & 3 \\
\hline Switzerland & $\begin{array}{l}\text { Repeated refusal of suitable job offers or to participate in ALMPs over a two year period } \\
\text { demonstrate that the unemployed is not available for work. This can result in an increase } \\
\text { in the length of suspension of benefit and subsequently in full suspension of benefits if the } \\
\text { unemployed is sanctioned several times for the same reason. The sanction applies after } \\
\text { the second or third refusal, depending on the attitude of the unemployed. }\end{array}$ & 4 \\
\hline Turkey & The unemployment benefit has already been suspended after the first refusal. & 5 \\
\hline $\begin{array}{l}\text { United } \\
\text { Kingdom }\end{array}$ & $\begin{array}{l}\text { Each time a jobseeker refuses employment without good cause a variable sanction will } \\
\text { apply. Each variable sanction can be } 1-26 \text { weeks depending on the circumstances of the } \\
\text { case. Repeated failure to attend a training scheme or employment programme without } \\
\text { good cause incurs a fixed sanction, the duration of which increases with every failure, from } \\
4 \text { weeks for the second failure up to a maximum of } 26 \text { weeks. }\end{array}$ & 3 \\
\hline $\begin{array}{l}\text { United } \\
\text { States }\end{array}$ & The unemployment benefit is generally suspended after the first refusal. & 5 \\
\hline
\end{tabular}




\section{ANNEX C: ADDITIONAL ITEMS ON MONITORING FOR SELECTED COUNTRIES}

Tables $\mathrm{C} 1$ and $\mathrm{C} 2$ outlines the frequency of intensive interviews in the first year of unemployment and report on the outcomes of job referrals in selected countries in the mid-2000s, respectively. Scores are allocated between 1 (least strict) and 5 (most strict), according to the methodology outlined in Box 2 . Information in the table is taken from OECD (2007) and its annex (available online at www.oecd.org/employment/outlook).

Table C1. Frequency of intensive interviews in the first year of unemployment, mid-2000s

\begin{tabular}{|c|c|c|}
\hline Country & Description & Score \\
\hline Australia & $\begin{array}{l}\text { When a jobseeker registers, Centrelink interviews jobseekers to assess their eligibility } \\
\text { for Job Network services and other appropriate services. Jobseekers eligible for Job } \\
\text { Network must usually meet with a Job Network member within } 14 \text { days of their contact } \\
\text { with Centrelink. Following three months of unemployment, a jobseeker meets with } \\
\text { their JNM to further develop their activity agreement. Subsequently, jobseekers are } \\
\text { required to attend interviews regularly, although the frequency varies widely. } \\
\text { Jobseekers entering Intensive Support customised assistance will have had four } \\
\text { intensive interviews in the first year. }\end{array}$ & 3 \\
\hline Austria & $\begin{array}{l}\text { The first interview takes place either at registration (about } 60 \%) \text { or within a period of } \\
\text { one month }(40 \%) \text {. Intensive interviews take place every three months as a minimum, } \\
\text { based on the client's individual action plan. }\end{array}$ & 3 \\
\hline Belgium & $\begin{array}{l}\text { Most jobseekers have at least a monthly interview after six to nine months of } \\
\text { unemployment. }\end{array}$ & 3 \\
\hline Czech Republic & Interviews take place in general twice a month, or in certain cases, once per month. & 5 \\
\hline Denmark & $\begin{array}{l}\text { The first meeting with the PES takes place within one month, at the meeting, } \\
\text { employability of the unemployed is profiled and his/her CV is discussed. The contact } \\
\text { interview with the PES takes place every three months. }\end{array}$ & 3 \\
\hline Finland & $\begin{array}{l}\text { The first intensive interview with the PES is suppose to take place within a month of } \\
\text { the initial registration. Intensive interviews take place according to a mutual agreement } \\
\text { between the PES and the jobseeker. They take place more frequently for younger } \\
\text { jobseekers and those at risk of long-term unemployment, and less so for older } \\
\text { jobseekers. }\end{array}$ & 2 \\
\hline Norway & $\begin{array}{l}\text { An intensive interview takes place within three weeks after preliminary registration. } \\
\text { Jobseekers are required to attend intensive interviews at least every three months, } \\
\text { unless they are attending labour market programmes. }\end{array}$ & 3 \\
\hline Slovak Republic & $\begin{array}{l}\text { The unemployed are asked to attend the PES for intensive interviews with } \\
\text { employment counsellors at least once a month. }\end{array}$ & 5 \\
\hline Spain & $\begin{array}{l}\text { Usually, the first intensive interview takes place either at registration or within a } \\
\text { maximum of } 15 \text { days. Other intensive interviews take place later in the unemployment } \\
\text { spell, depending on participation in programmes, and with an average of six interviews } \\
\text { per year. }\end{array}$ & 4 \\
\hline Sweden & $\begin{array}{l}\text { The first intensive interview takes place within thirty days after official registration. } \\
\text { Normally, there is a follow-up dialogue concerning an adult's job-seeking activities } \\
\text { within the framework of their individual action plan every } 6-8 \text { weeks. }\end{array}$ & 4 \\
\hline United Kingdom & $\begin{array}{l}\text { After the initial registration, an initial work-focused interview is undertaken. } 60 \% \text { of } \\
\text { these meetings occur within the four-day target, } 74 \% \text { within two weeks. Intensive } \\
\text { interviews are attended on a quarterly basis. }\end{array}$ & 3 \\
\hline
\end{tabular}


DELSA/ELSA/WD/SEM(2012)1

Table C2. Reports on the outcome of job referrals, mid-2000s

\begin{tabular}{|c|c|c|}
\hline Country & Description & Score \\
\hline Australia & $\begin{array}{l}\text { The employer is under no legal obligation to report on the outcome of referrals, } \\
\text { however it is considered best practice to obtain feedback regarding the outcome of the } \\
\text { interview and any reasons for hire or non-hire of a jobseeker. }\end{array}$ & 1 \\
\hline Austria & $\begin{array}{l}\text { Employers are asked to report on the outcome of an application, and to list the } \\
\text { reasons for not employing a particular candidate on a form sent back to the PES. } \\
\text { Jobseekers are asked by the PES to report on the outcome of the applications as well. }\end{array}$ & 5 \\
\hline Belgium & $\begin{array}{l}\text { Employers must report to the PES on the results of the interview and the reasons why } \\
\text { the jobseeker was not engaged, if this is the case. There is a standard form which the } \\
\text { jobseeker gives to the employer. Jobseekers are also required to update their } \\
\text { employment counsellor on the results of interviews. }\end{array}$ & 5 \\
\hline Czech Republic & $\begin{array}{l}\text { The Labour Office requires that jobseekers report on the results of interviews. If the } \\
\text { jobseeker has an individual action plan, the Office also asks about the reasons why } \\
\text { the jobseeker was not hired. }\end{array}$ & 3 \\
\hline Denmark & $\begin{array}{l}\text { Both the employer and the jobseeker are asked to report the outcome of the job } \\
\text { application. }\end{array}$ & 5 \\
\hline Finland & $\begin{array}{l}\text { The employer is asked to report to the local PES when the vacancy is filled and asked } \\
\text { to report the name of the accepted person. If the local PES has made direct referrals, } \\
\text { the outcome of each referral will be checked. The referred jobseeker will also be } \\
\text { asked about the outcome of the referral and the application. }\end{array}$ & 5 \\
\hline Norway & $\begin{array}{l}\text { In case of direct referrals, the employer is asked to report back as to which candidate } \\
\text { obtained the job. The PES will often follow up by asking about the reason why certain } \\
\text { candidates were not hired. Referred jobseekers are also asked to report the outcome. }\end{array}$ & 5 \\
\hline Slovak Republic & $\begin{array}{l}\text { The employer usually states the result of the referral on paper (often a standard form, } \\
\text { but other statements are also accepted) which the referred jobseeker is asked either } \\
\text { to deliver to the PES office within three working days, or to present at his/her next visit } \\
\text { to the PES. }\end{array}$ & 4 \\
\hline Spain & $\begin{array}{l}\text { The employer is, in principle, invited to give the reasons why the candidate was not } \\
\text { selected. In addition, employers are required to send the PES copies of any new } \\
\text { contracts or extensions of existing ones. }\end{array}$ & 4 \\
\hline Sweden & $\begin{array}{l}\text { The employer is not asked to report the outcome of the job application. The jobseeker } \\
\text { is required to do } s \text { if the PES demands a report. }\end{array}$ & 3 \\
\hline United Kingdom & $\begin{array}{l}\text { The claimant is asked to fill in a form at every fortnightly signing. This form asks for } \\
\text { details of each application and the outcome. }\end{array}$ & 3 \\
\hline
\end{tabular}

Source: OECD (2007). 


\section{REFERENCES}

Abbring, J., G. van den Berg and J. van Ours (2005), "The Effect of Unemployment Insurance Sanctions on the Transition Rate from Unemployment to Employment", Economic Journal, Vol. 115, pp. 602630 .

Belzil, C. (2001), "Unemployment Insurance and Subsequent Job Duration: Job Matching versus Unobserved Heterogeneity", Journal of Applied Econometrics, Vol. 19, pp. 619-636.

Boone, J. and J. van Ours (2006), "Modelling Financial Incentives to Get Unemployed Back to Work", Journal of Institutional and Theoretical Economics, Vol. 162, No. 2, pp. 227-252.

Boone, J., P. Fredriksson, B. Holmlund and J. van Ours (2007), “Optimal Unemployment Insurance with Monitoring and Sanctions”, Economic Journal, Vol. 117, pp. 399-421.

Boone, J., A. Sadrieh and J. van Ours (2009), "Experiments on Unemployment Benefit Sanctions and Job Search Behaviour", European Economic Review, Vol. 53, pp. 937-951.

Council of Europe (2009), Guide to the Concept of Suitable Employment in the Context of Unemployment Benefits, Council of Europe Publishing, Strasbourg.

Fredriksson, P. and B. Holmlund (2006), "Improving Incentives in Unemployment Insurance: A Review of Recent Research”, Journal of Economic Surveys, Vol. 20, No. 3, pp. 357-386.

Grubb (2001), "Eligibility Criteria for Unemployment Benefits", in OECD, Labour Market Policies and the Public Employment Service, OECD Publishing, Paris.

Hasselpflug, S. (2005), Availability Criteria in 25 Countries, Danish Ministry of Finance Working Paper No. 12, Copenhagen.

Hofmann, B. (2008), Work Incentives? Ex-Post Effects of Unemployment Sanctions - Evidence from West Germany, IAB Discussion Paper No. 43/2008, Institute for Employment Research, Nuremberg.

Jensen, P. M. Rosholm and M. Svarer (2003), "The Response of Youth Unemployment to Benefits, Incentives, and Sanctions", European Journal of Political Economy, Vol. 19, pp. 301-316.

Johnson, T. and D. Klepinger (1994), "Experimental Evidence on Unemployment Insurance Work-Search Policies", Journal of Human Resources, Vol. 29, No. 3, pp. 695-717.

Lalive, R., J. Zweimuller and J. van Ours (2005), "The Effect of Benefit Sanctions on the Duration of Unemployment", Journal of the European Economic Association, Vol. 3, No. 6, pp. 1386-1417.

Ljungqvist, L. and T. Sargent (1995), "The Swedish Unemployment Experience”, European Economic Review, Vol. 39, pp. 1043-1070. 
Ministry of Finance (1998), Availability Criteria in Selected OECD-Countries, Danish Ministry of Finance Working Paper No. 6, Copenhagen.

OECD (2006), Employment Outlook, OECD Publishing, Paris.

OECD (2007), Employment Outlook, OECD Publishing, Paris.

Olsson, M. (2009), "Matching in the Labour Market: Modelling Spatial Aspects of the Swedish Unemployment Benefit Rules", Annals of Regional Science, Vol. 43, pp. 345-363.

van den Berg, G., B. van der Klaauw and J. van Ours (2004), "Punitive Sanctions and the Transition Rate from Welfare to Work", Journal of Labor Economics, Vol. 22, No. 1, pp. 211-241. 


\section{OECD SOCIAL, EMPLOYMENT AND MIGRATION WORKING PAPERS}

Most recent releases are:

No. 127 THE LABOUR MARKET INTEGRATION OF IMMIGRANTS AND THEIR CHILDREN IN AUSTRIA Karolin Krause and Thomas Liebig (2011)

No. 126 ARE RECENT IMMIGRANTS DIFFERENT? A NEW PROFILE OF IMMIGRANTS IN THE OECD BASED ON DIOC 2005/06 Sarah Widmaier and Jean-Christophe Dumont (2011)

No. 125 EARNINGS VOLATILITY AND ITS CONSEQUENCES FOR HOUSEHOLDS Danielle Venn (2011)

No. 124 CRISIS, RECESSION AND THE WELFARE STATE Willem Adema, Pauline Fron and Maxime Ladaique (2011)

No. 123 AGGREGATE EARNINGS AND MACROECONOMIC SHOCKS Andrea Bassanini (2011)

No. 122 REDISTRIBUTION POLICY AND INEQUALITY REDUCTION IN OECD COUNTRIES: WHAT HAS CHANGED IN TWO DECADES? Herwig Immervoll, Linda Richardson (2011)

No. 121 OVER-QUALIFIED OR UNDER-SKILLED Glenda Quintini (2011)

No. 120 RIGHT FOR THE JOB Glenda Quintini (2011)

No.119 THE LABOUR MARKET EFFECTS OF UNEMPLOYMENT COMPENSATION IN BRAZIL Alexander Hijzen (2011)

No. 118 EARLY MATERNAL EMPLOYMENT AND CHILD DEVELOPMENT IN FIVE OECD COUNTRIES Maria del Carmen Huerta, Willem Adema, Jennifer Baxter, Miles Corak, Mette Deding, Matthew C.Gray, Wen-Jui Han, Jane Waldfogel (2011)

No. 117 WHAT DRIVES INFLOWS INTO DISABILITY?EVIDENCE FROM THREE OECD COUNTRIES Ana Llena-Nozal and Theodora Xenogiani (2011)

No. 116 COOKING, CARING AND VOLUNTEERING: UNPAID WORK AROUND THE WORLD Veerle Miranda (2011)

No. 115 THE ROLE OF SHORT-TIME WORK SCHEMES DURING THE 2008-09 RECESSION Alexander Hijzen and Danielle Venn (2010)

No. 114 INTERNATIONAL MIGRANTS IN DEVELOPED, EMERGING AND DEVELOPING COUNTRIES: AN EXTENDED PROFILE

Jean-Christophe Dumont, Gilles Spielvogel and Sarah Widmaier (2010)

No. 113 ACTIVATION POLICIES IN JAPAN

Nicola Duell, David Grubb, Shruti Singh and Peter Tergeist (2010)

No. 112 ACTIVATION POLICIES IN SWITZERLAND

Nicola Duell and Peter Tergeist with contributions from Ursula Bazant and Sylvie Cimper (2010)

No. 111 ECONOMIC DETERMINANTS AND CONSEQUENCES OF CHILD MALTREATMENT Lawrence M. Berger, Jane Waldfogel (forthcoming)

No. 110 DISTRIBUTIONAL CONSEQUENCES OF LABOR DEMAND ADJUSTMENTS TO A DOWNTURN: A MODEL-BASED APPROACH WITH APPLICATION TO GERMANY 2008-09 Herwig Immervoll, Olivier Bargain, Andreas Peichl, Sebastian Siegloch (2010)

No. 109 DECOMPOSING NOTIONAL DEFINED-CONTRIBUTION PENSIONS: EXPERIENCE OF OECD COUNTRIES'REFORMS

Edward Whitehouse (2010) 
No. 108 EARNINGS OF MEN AND WOMEN WORKING IN THE PRIVATE SECTOR: ENRICHED DATA FOR PENSIONS AND TAX-BENEFIT MODELING

Anna Cristina D'Addio and Herwig Immervoll (2010)

No. 107 INSTITUTIONAL DETERMINANTS OF WORKER FLOWS: A CROSS-COUNTRY/CROSS-INDUSTRY APPROACH

Andrea Bassanini, Andrea Garnero, Pascal Marianna, Sebastien Martin (2010)

No. 106 RISING YOUTH UNEMPLOYMENT DURING THE CRISIS: HOW TO PREVENT NEGATIVE LONG-TERM CONSEQUENCES ON A GENERATION?

Stefano Scarpetta, Anne Sonnet and Thomas Manfredi (2010)

No. 105 TRENDS IN PENSION ELIGIBILITY AGES AND LIVE EXPECTANCY, 1950-2050

Rafal Chomik and Edward Whitehouse (2010)

No. 104 ISRAELI CHILD POLICY AND OUTCOMES

John Gal, Mimi Ajzenstadt, Asher Ben-Arieh, Roni Holler and Nadine Zielinsky (2010)

No. 103 REFORMING POLICIES ON FOREIGN WORKERS IN ISRAEL Adriana Kemp (2010)

No. 102 LABOUR MARKET AND SOCIO-ECONOMIC OUTCOMES OF THE ARAB-ISRAELI POPULATION Jack Habib, Judith King, Asaf Ben Shoham, Abraham Wolde-Tsadick and Karen Lasky (2010)

No. 101 TRENDS IN SOUTH AFRICAN INCOME DISTRIBUTION AND POVERTY SINCE THE FALL OF APARTHEID

Murray Leibbrandt, Ingrid Woolard, Arden Finn and Jonathan Argent (2010)

No. 100 MINIMUM-INCOME BENEFITS IN OECD COUNTRIES: POLICY DESIGN, EFFECTIVENESS AND CHALLENGES

Herwig Immervoll (2009)

No. 99 HAPPINESS AND AGE CYCLES - RETURN TO START...? ON THE FUNCTIONAL RELATIONSHIP BETWEEN SUBJECTIVE WELL-BEING AND AGE Justina A.V. Fischer (2009)

No. 98 ACTIVATION POLICIES IN FINLAND

Nicola Duell, David Grubb and Shruti Singh (2009)

No. 97 CHILDREN OF IMMIGRANTS IN THE LABOUR MARKETS OF EU AND OECD COUNTRIES: AN OVERVIEW

Thomas Liebig and Sarah Widmaier (2009)

A full list of Social, Employment and Migration Working Papers is available at www.oecd.org/els/workingpapers.

Other series of working papers available from the OECD include: OECD Health Working Papers. 